\title{
Variability in Lotic Communities in Three Contrasting Stream Environments in the Santa Ana River Basin, California, 1999-2001
}

Scientific Investigations Report 2008-5217

U.S. DEPARTMENT OF THE INTERIOR

U.S. GEOLOGICAL SURVEY
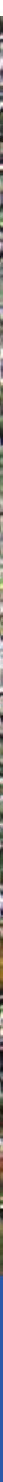

National Water-Quality Assessment Program 
Front cover description and credits:

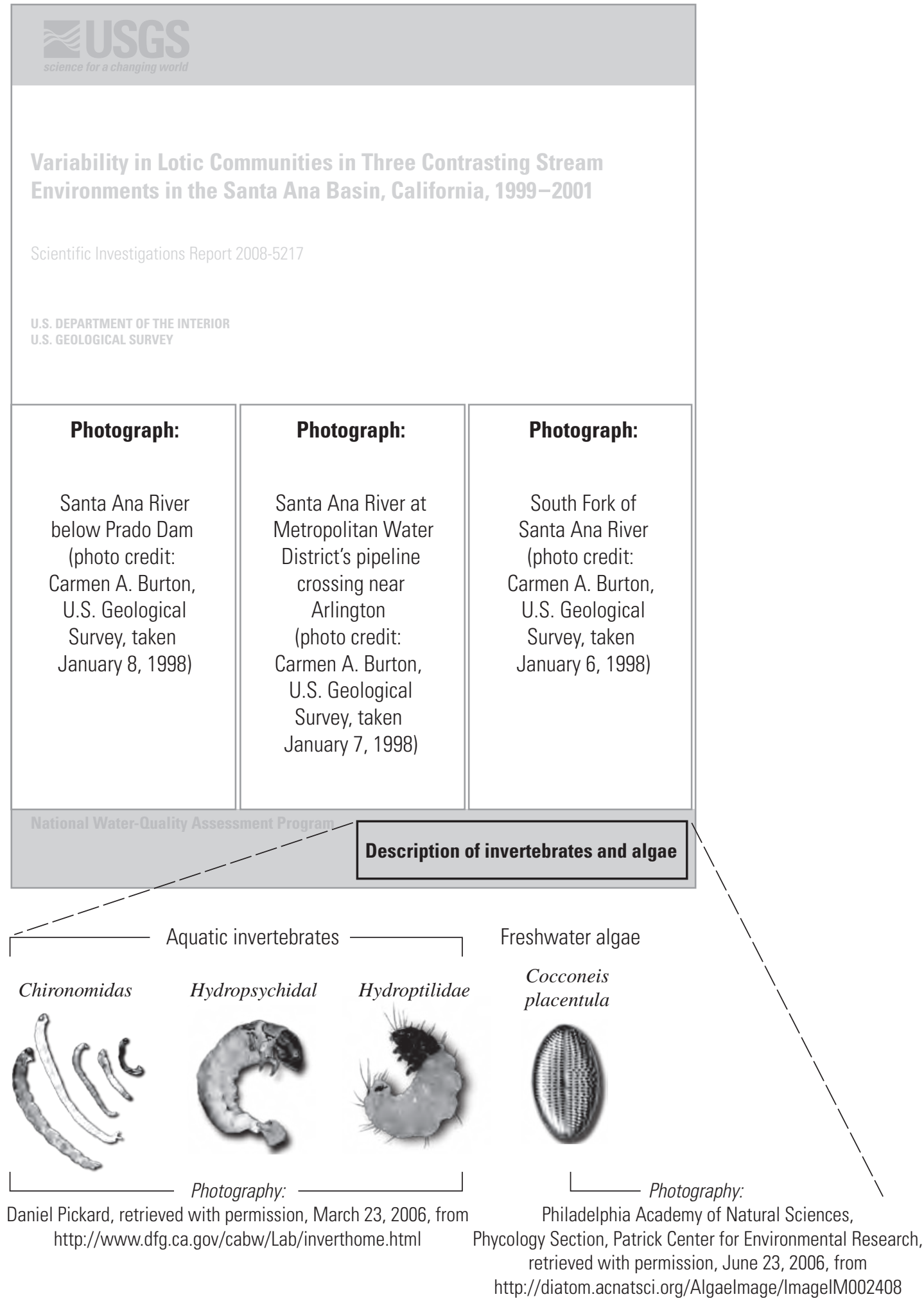




\section{Variability in Lotic Communities in Three Contrasting Stream Environments in the Santa Ana River Basin, California, 1999-2001}

By Carmen A. Burton

National Water-Quality Assessment Program

Scientific Investigations Report 2008-5217 


\section{U.S. Department of the Interior DIRK KEMPTHORNE, Secretary}

\section{U.S. Geological Survey \\ Mark D. Myers, Director}

\section{U.S. Geological Survey, Reston, Virginia: 2009}

For product and ordering information:

World Wide Web: http://www.usgs.gov/pubprod

Telephone: 1-888-ASK-USGS

For more information on the USGS--the Federal source for science about the Earth, its natural and living resources, natural hazards, and the environment:

World Wide Web: http://www.usgs.gov

Telephone: 1-888-ASK-USGS

Any use of trade, product, or firm names is for descriptive purposes only and does not imply endorsement by the U.S. Government.

Although this report is in the public domain, permission must be secured from the individual copyright owners to reproduce any copyrighted materials contained within this report.

Suggested reference:

Burton, C.A., 2009, Variability in lotic communities in three contrasting stream environments in the Santa Ana River Basin, California, 1999-2001: U.S. Geological Survey Scientific Investigations Report 2008-5217, 77 p. Available at http://pubs.usgs.gov/sir/2008/5217/ 


\section{FOREWORD}

The U.S. Geological Survey (USGS) is committed to providing the Nation with credible scientific information that helps to enhance and protect the overall quality of life and that facilitates effective management of water, biological, energy, and mineral resources (http://www.usgs.gov/). Information on the Nation's water resources is critical to ensuring long-term availability of water that is safe for drinking and recreation and is suitable for industry, irrigation, and fish and wildlife. Population growth and increasing demands for water make the availability of that water, now measured in terms of quantity and quality, even more essential to the long-term sustainability of our communities and ecosystems.

The USGS implemented the National Water-Quality Assessment (NAWQA) Program in 1991 to support national, regional, State, and local information needs and decisions related to water-quality management and policy (http://water.usgs.gov/nawqa). The NAWQA Program is designed to answer: What is the condition of our Nation's streams and ground water? How are conditions changing over time? How do natural features and human activities affect the quality of streams and ground water, and where are those effects most pronounced? By combining information on water chemistry, physical characteristics, stream habitat, and aquatic life, the NAWQA Program aims to provide science-based insights for current and emerging water issues and priorities. From 1991-2001, the NAWQA Program completed interdisciplinary assessments and established a baseline understanding of water-quality conditions in 51 of the Nation's river basins and aquifers, referred to as Study Units (http://water.usgs.gov/nawqa/studyu.html).

Multiple national and regional assessments are ongoing in the second decade (2001-2012) of the NAWQA Program as 42 of the 51 Study Units are reassessed. These assessments extend the findings in the Study Units by determining status and trends at sites that have been consistently monitored for more than a decade, and filling critical gaps in characterizing the quality of surface water and ground water. For example, increased emphasis has been placed on assessing the quality of source water and finished water associated with many of the Nation's largest community water systems. During the second decade, NAWQA is addressing five national priority topics that build an understanding of how natural features and human activities affect water quality, and establish links between sources of contaminants, the transport of those contaminants through the hydrologic system, and the potential effects of contaminants on humans and aquatic ecosystems. Included are topics on the fate of agricultural chemicals, effects of urbanization on stream ecosystems, bioaccumulation of mercury in stream ecosystems, effects of nutrient enrichment on aquatic ecosystems, and transport of contaminants to public-supply wells. These topical studies are conducted in those Study Units most affected by these issues; they comprise a set of multi-Study-Unit designs for systematic national assessment. In addition, national syntheses of information on pesticides, volatile organic compounds (VOCs), nutrients, selected trace elements, and aquatic ecology are continuing.

The USGS aims to disseminate credible, timely, and relevant science information to address practical and effective water-resource management and strategies that protect and restore water quality. We hope this NAWQA publication will provide you with insights and information to meet your needs, and will foster increased citizen awareness and involvement in the protection and restoration of our Nation's waters.

The USGS recognizes that a national assessment by a single program cannot address all water-resource issues of interest. External coordination at all levels is critical for cost-effective management, regulation, and conservation of our Nation's water resources. The NAWQA Program, therefore, depends on advice and information from other agencies-Federal, State, regional, interstate, Tribal, and local-as well as nongovernmental organizations, industry, academia, and other stakeholder groups. Your assistance and suggestions are greatly appreciated.

Matthew C. Larsen

Associate Director for Water 


\section{Contents}

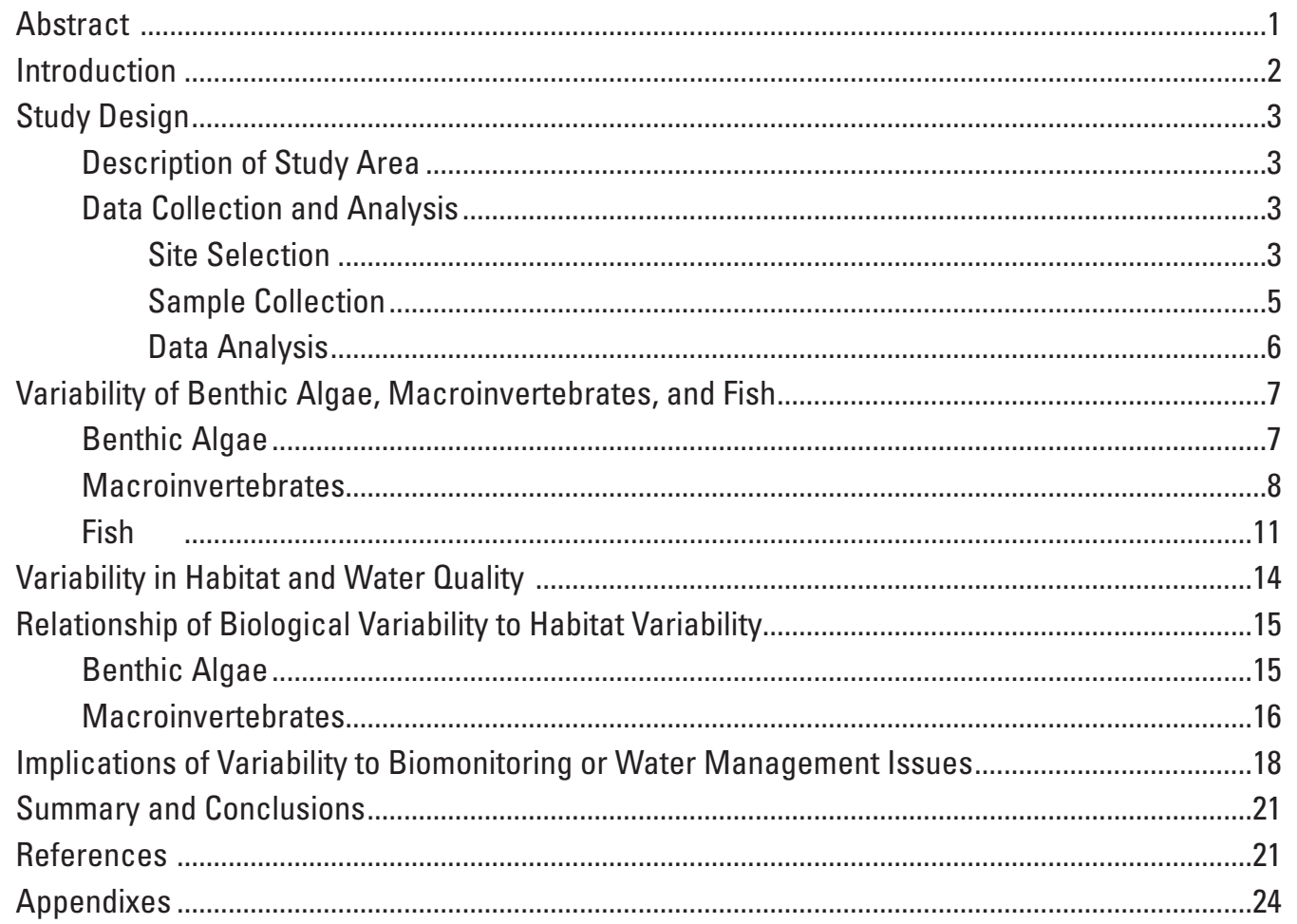

\section{Figures}

Figure 1. Map showing location of study area, ecology sites, landuse, and ecoregions within the study area

Figure 2. Cluster dendrogram showing the results of an unweighted group average linkage cluster analysis of benthic algae data collected from four sites (SF, UPH, MWD, and PRD) in the Santa Ana River Basin, California, 1999-2001

Figure 3. Cluster dendrogram showing the results of an unweighted group average linkage cluster analysis of macroinvertebrate data collected from four sites (SF, UPH, MWD, and PRD) in the Santa Ana River Basin, California, 1999-2001

Figure 4. Cluster dendrogram showing the results of an unweighted group average linkage cluster analysis of fish data collected from four sites (SF, UPH, MWD, and PRD) in the Santa Ana River Basin, California, 1999-2001

Figure 5. Graphs showing the relationships of the coefficient of variation of selected habitat variables to the coefficient of variation of selected benthic algae metrics collected at three sites (SF, MWD, and PRD) in the Santa Ana River Basin, California, 1999-2001

Figure 6. Graphs showing the relationships of the coefficient of variation of selected habitat variables to the coefficient of variation of selected macroinvertebrate metrics collected at three sites (SF, MWD, and PRD) in the Santa Ana River Basin, California, 1999-2001 


\section{Tables}

Table 1. Sites sampled for benthic algae, macroinvertebrates, fish, and habitat assessment during the summers of 1999, 2000, and 2001 in the Santa Ana River Basin, California ................................................

Table 2. Physical habitat variables measured and method of measurement, during the summers of 1999, 2000, and 2001, at four sites in the Santa Ana River Basin, California

Table 3. Coefficients of variation for benthic algae metrics that showed significant differences between sites, Santa Ana River Basin, California, 1999-2001 _.... 9

Table 4. Coefficients of variation for benthic macroinvertebrate metrics that showed significant differences among three sites, Santa Ana River Basin, California,

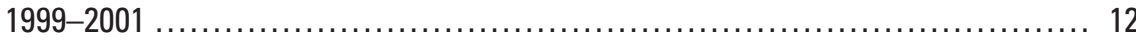

Table 5. Coefficients of variation of habitat variables for the three summers of 1999-2001 for three sites in the Santa Ana River Basin, California

Table 6. Benthic algae metric coefficients of variation that show a positive or negative association with the coefficient of variation of at least one habitat variable $\quad \ldots 17$

Table 7. Macroinvertebrate metric coefficient of variations that show a positive or negative association with the coefficient of variation of at least one habitat variable

\section{Appendix tables}

Appendix 1. Values for environmental variables measured during summers of 1999, 2000, and 2001 at four sites in the Santa Ana River Basin, California

Appendix 2. Benthic algae taxa collected from four sites in the Santa Ana River Basin, California, 1999-2001

Appendix 3. Benthic algae taxa and their densities from richest-targeted habitat samples collected from four sites in the Santa Ana River Basin, California, 1999-2001 ... 36

Appendix 4. Benthic algae taxa and their densities from depositional-targeted habitat samples collected from four sites in the Santa Ana River Basin, California, 1999-2001

Appendix 5. Benthic algae metrics calculated from qualitative multihabitat, richesttargeted habitat, and depositional-targeted habitat samples collected from four sites in the Santa Ana River Basin, California, 1999-2001

Appendix 6. Macroinvertebrate taxa collected from four sites in the Santa Ana River Basin, California, 1999-2001 54

Appendix 7. Macroinvertebrate taxa from richest-targeted habitat samples collected from four sites in the Santa Ana River Basin, California, 1999-2001 63

Appendix 8. Macroinvertebrate metrics calculated from qualitative and richest-targeted samples from four sites in the Santa Ana River Basin, California, 1999-2001 . . 70

Appendix 9. Data from fish collected from four sites during the summers 1999-2001 in the Santa Ana River Basin, California 


\section{Abbreviations and Acronyms}

(Clarification or additional information given in parentheses)

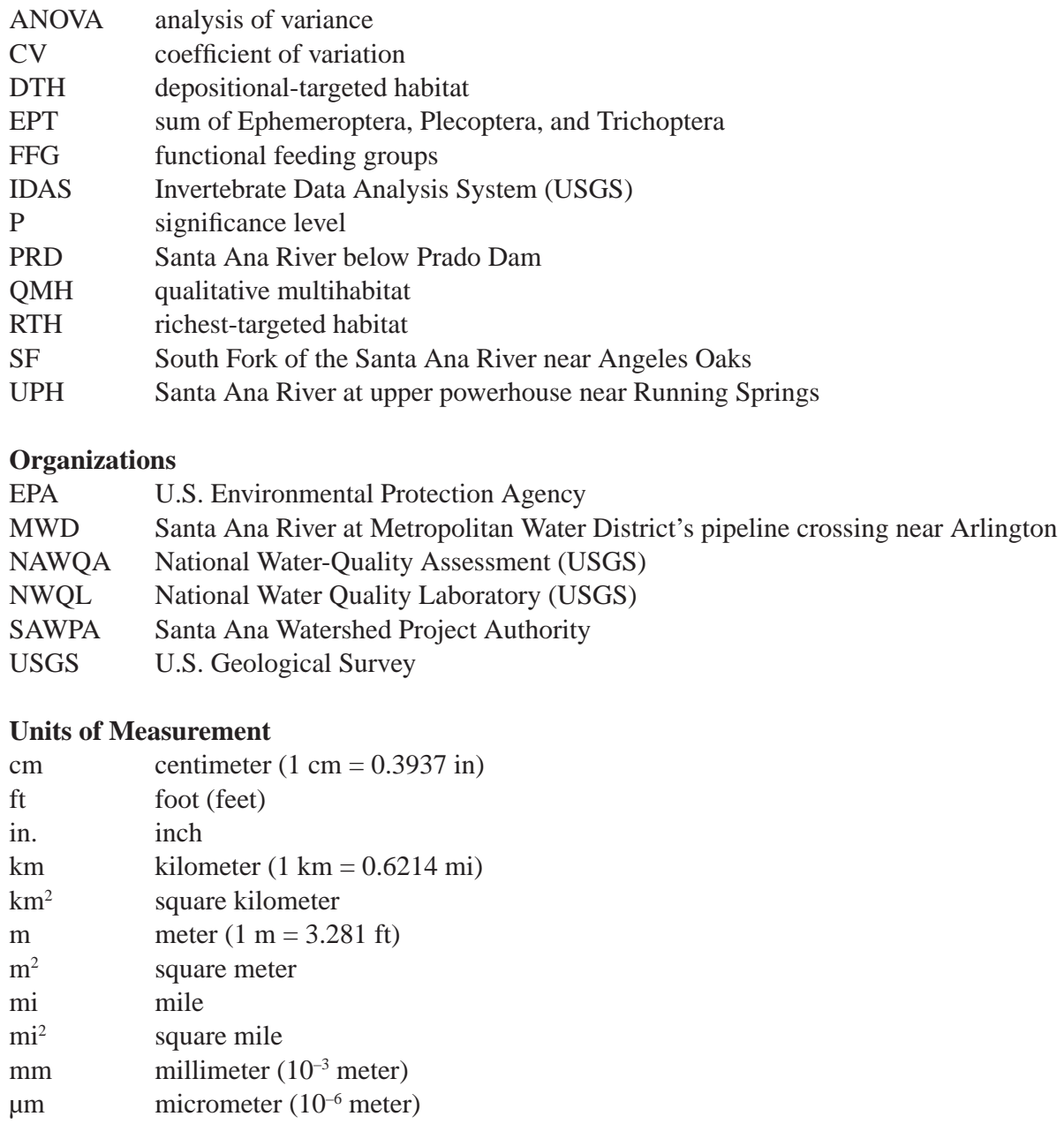

\section{Notes}

Temperature in degrees Celsius $\left({ }^{\circ} \mathrm{C}\right)$ may be converted to degrees Fahrenheit $\left({ }^{\circ} \mathrm{F}\right)$ as follows:

$$
{ }^{\circ} \mathrm{F}=\left(1.8 \times{ }^{\circ} \mathrm{C}\right)+32
$$

Vertical coordinate information is referenced to the North American Vertical Datum of 1988 (NAVD 88).

Horizontal coordinate information is referenced to the North American Datum of 1983 (NAD 83).

Altitude, as used in this report, refers to distance above the vertical datum.

Specific conductance is given in microsiemens per centimeter at 25 degrees Celsius $(\mu \mathrm{S} / \mathrm{cm}$ at $\left.25^{\circ} \mathrm{C}\right)$. 


\title{
Variability in Lotic Communities in Three Contrasting Stream Environments in the Santa Ana River Basin, California, 1999-2001
}

\author{
By Carmen A. Burton
}

\begin{abstract}
Biotic communities and environmental conditions can be highly variable between natural ecosystems. The variability of natural assemblages should be considered in the interpretation of any ecological study when samples are either spatially or temporally distributed. Little is known about biotic variability in the Santa Ana River Basin. In this report, the lotic community and habitat assessment data from ecological studies done as part of the U.S. Geological Survey's National Water-Quality Assessment (NAWQA) program are used for a preliminary assessment of variability in the Santa Ana Basin.

Habitat was assessed, and benthic algae, benthic macroinvertebrate, and fish samples were collected at four sites during 1999-2001. Three of these sites were sampled all three years. One of these sites is located in the San Bernardino Mountains, and the other two sites are located in the alluvial basin. Analysis of variance determined that the three sites with multiyear data were significantly different for 41 benthic algae metrics and 65 macroinvertebrate metrics and fish communities. Coefficients of variation (CVs) were calculated for the habitat measurements, metrics of benthic algae, and macroinvertebrate data as measures of variability. Annual variability of habitat data was generally greater at the mountain site than at the basin sites. The mountain site had higher CVs for water temperature, depth, velocity, canopy angle, streambed substrate, and most water-quality variables. In general, $\mathrm{CVs}$ of most benthic algae metrics calculated from the richest-targeted habitat $(\mathrm{RTH})$ samples were greater
\end{abstract}

at the mountain site. In contrast, $\mathrm{CVs}$ of most benthic algae metrics calculated from depositional-targeted habitat (DTH) samples were lower at the mountain site. In general, CVs of macroinvertebrate metrics calculated from qualitative multihabitat $(\mathrm{QMH})$ samples were lower at the mountain site. In contrast, CVs of many metrics calculated from RTH samples were greater at the mountain site than at one of the basin sites. Fish communities were more variable at the basin sites because more species were present at these sites.

Annual variability of benthic algae metrics was related to annual variability in habitat variables. The CVs of benthic algae metrics related to the most CVs of habitat variables included QMH taxon richness, the RTH percentage richness, RTH abundance of tolerant taxa, RTH percentage richness of halophilic diatoms, RTH percentage abundance of sestonic diatoms, DTH percentage richness of nitrogen heterotrophic diatoms, and DTH pollution tolerance index. The CVs of macroinvertebrate metrics related to the most $\mathrm{CVs}$ of habitat variables included the RTH trichoptera, RTH EPT, RTH scraper richness, RTH nonchironomid dipteran abundance (in percent), and RTH EPA (U.S. Environmental Protection Agency) tolerance, which is based on abundance. Many of the CVs of habitat variables related to CVs of macroinvertebrate metrics were the same habitat variables that were related to the CVs of benthic algae metrics. On the basis of these results, annual variability may have a role in the relationship of benthic algae and macroinvertebrates assemblages with habitat and water quality in the Santa Ana Basin. This report provides valuable baseline data on the variability of biological communities in the Santa Ana Basin. 


\section{Introduction}

Biotic communities and habitat conditions are known to be highly heterogeneous in natural ecosystems. This heterogeneity is observed at multiple spatial scales ranging from river systems to microhabitats within stream reaches. Variability of natural assemblages should be considered in the interpretation of any ecological study when samples are either spatially or temporally distributed.

Variance of community composition or habitat can be a factor with ecological relevance (Palmer and others, 1997). Many papers (some cited by Palmer and others, 1997) suggest three reasons why studying variance in biotic communities or habitat may aid in understanding stream ecosystems. First, factors that affect ecological processes may be identified by a close examination of individual data points that contribute to variance. Second, changes in variance with spatial scale may lead to a better understanding of stream ecosystems. And third, identification of domains, areas of scale where the variance of a factor does not change (Wiens, 1989), also may lead to better understanding of stream ecosystems.

Effects of variability in benthic algae or habitat have not been studied extensively. However, Cardinale and others (2002) found that increased habitat heterogeneity resulted in increased primary productivity of stream algae. Large spatial variability was observed in some marine algae within similar habitats at the local scale (Wahl, 2001). On the other hand, variability in benthic macroinvertebrate assemblages has been studied for many years. Needham and Usinger (1956) studied the macroinvertebrate genera in a riffle in Prosser Creek, near Truckee, California, and found that most genera preferred moderate depths and velocities. In more recent studies, variation in macroinvertebrates was found at scales as small as groups (patches) of stones (Barmuta, 1990; Downes and others, 1993; Palmer and others, 2000). For example, in a northern Virginia stream, the spatial arrangement of patches or microhabitats was correlated to macroinvertebrate abundance (Palmer and others, 2000). In central Texas, a greater abundance of most macroinvertebrates was found toward the heads of riffles (Brown and Brown, 1984), which contrasts with the findings in Prosser Creek by Needham and Usinger (1956). In northern New Hampshire, benthic macroinvertebrate richness increased and macroinvertebrate variability decreased with increasing habitat heterogeneity (Brown, 2003). In two rivers with different channel forms in New Zealand, seasonal variation in species composition was lower in the river that had the less stable streambed substrate (Fowler and Death, 2000). Spatial variation in macroinvertebrates also occurs at larger scales, such as between streams or ecoregions, for macroinvertebrate richness metrics (Li and others, 2001). All these studies indicate a relationship between macroinvertebrate variability and habitat.
Several studies indicate that variation in fish assemblages is correlated to environmental variables or variation in these variables. Herbert and Gelwick (2003) explained variation in fish assemblages in a Texas stream by instream structure, hydrologic and physicochemical factors, and drainage features. In Minnesota and North Dakota, some species of fish were correlated with low variability in physical and chemical variables (Koel and Peterka, 2003). In central Europe, Slavik and Bartos (2001) observed decreased variation in fish assemblages in response to anthropogenic increases in variation in the physical environment, specifically for dissolved oxygen. Fayram and others (2005) observed higher variability of index of biotic integrity scores for cold-water fish in smaller Wisconsin streams compared with larger streams.

Because factors affecting variability of biota depend on scale (Andrew and others, 2003; Heino and others, 2003; Li and others 2001; Wiens, 1989), scale needs to be considered when changes in biological communities are assessed over space. This could partially explain why findings of different studies do not always agree (Wiens, 1989).

Few studies of biological communities have been conducted in the Santa Ana River Basin. The U.S. Forest Service has collected biological data pertaining to forest lands, especially data on fish populations. The Santa Ana Watershed Project Authority (SAWPA) funded a study to determine the attainable uses of the Santa Ana River, especially in the inland basin. The U.S. Fish and Wildlife Service, the California Department of Fish and Game, and SAWPA are involved in a study to devise strategies to aid the endangered Santa Ana sucker. Very few studies of macroinvertebrates or benthic algae have been conducted in the basin and none have addressed the issues of spatial or annual variability.

The U.S. Geological Survey (USGS) incorporated ecological studies as part of the National Water-Quality Assessment (NAWQA) program (Gilliom and others, 1995). The Santa Ana Basin is one of more than 50 major river basins in the United States (U.S.) included in the NAWQA program. One purpose of these studies is to use the condition of aquatic biological communities as an indicator of the physical and chemical condition of water and hydrologic systems in the U.S. (Gilliom and others, 1995). The data from the Santa Ana NAWQA study was used for a preliminary assessment of variability in the Santa Ana Basin.

The purposes of this report are to assess (1) annual variability at each site for various biological measures, (2) the relationship of variability in biological measures to habitat and water quality variability, and (3) implications of any such relationship for biomonitoring or water management issues in the Santa Ana Basin. In addition, biological community information and habitat assessment data are listed in the appendixes. 


\section{Study Design}

\section{Description of Study Area}

The Santa Ana River Basin is the largest stream system in southern California, encompassing almost $6,900 \mathrm{~km}^{2}$ $\left(2,670 \mathrm{mi}^{2}\right)$ of densely populated coastal area (fig. 1). The river begins in the San Bernardino Mountains (which reach altitudes exceeding 3,000 $\mathrm{m}(10,000 \mathrm{ft}))$ and flows more than $160 \mathrm{~km}(100 \mathrm{mi})$ to the Pacific Ocean. The watershed is home to almost 4.8 million people, and the population is expected to reach 7 million by the year 2025 (Santa Ana Watershed Project Authority, accessed June 9, 2003).

The basin is divided between two ecoregions, the Southern California Mountains ecoregion and the Southern and Central California Chaparral and Oak Woodlands ecoregion (U.S. Environmental Protection Agency, accessed September 3, 2004). Most of the urban and agricultural land uses occur in the alluvium-filled valleys and coastal plains of the Southern and Central California Chaparral and Oak Woodlands ecoregion (fig. 1).

The basin has a Mediterranean climate, characterized by hot, dry summers and cool, wet winters. Average annual precipitation ranges from about 25 to $60 \mathrm{~cm}$ (10 to $24 \mathrm{in}$.) in the coastal plains and inland valleys, and from 60 to 120 cm (24 to 48 in.) in the San Gabriel and San Bernardino Mountains (U.S. Army Corps of Engineers, 1994). This study started at the beginning of a drought period with annual precipitation well below the norm (Belitz and others, 2004).

The hydrologic system of the basin has been greatly altered. At higher elevations in the mountains, the streams are relatively unaltered except for intense recreational use and some diversions for hydroelectric power production on the Santa Ana River. At the transition from the mountains to the valley, most streams are diverted directly to public drinking-water supplies or to ground-water-recharge facilities. As a result of these alterations to the system and the natural Mediterranean climate, streams generally do not flow onto the valley floor, except during large stormflows that exceed the capacity of the diversions.

Flow is re-established in many low-elevation valley streams by various combinations of urban runoff, ground water, or discharges from wastewater treatment plants. These streams are composed of 70-100 percent treated wastewater (Mendez and Belitz, 2002). All of the base-flow of the river is diverted to a ground-water-recharge facility several miles downstream of Prado Dam. During the period of this study (summer 1999 to summer 2001), precipation was less than the 30-year average. Streamflows in many tributaries to the Santa Ana River were generally near historical lows during baseflow conditions.

\section{Data Collection and Analysis}

\author{
Site Selection
}

The Santa Ana Basin study design for NAWQA included seven surface-water fixed sites as part of a surface-water network. These sites were chosen to either represent stream water-quality conditions resulting from a specific land use or to represent stream water-quality conditions resulting from a combination of land uses and other influences. Ecology studies were not carried out at three of the fixed sites because the channels were completely or partially concrete-lined. The four remaining sites ranged from high in the San Bernardino Mountains near the headwaters of the Santa Ana River to just below Prado Dam (fig. 1). These four sites are listed in table 1.

The first site is located on the South Fork of the Santa Ana River near Angeles Oaks in the San Bernardino Mountains (hereinafter, SF). It is an alpine site located in the Southern California Mountains ecoregion (U.S. Environmental Protection Agency, accessed Sept. 3, 2004). The stream channel consists mostly of bedrock, boulders, and cobbles. Land use is undeveloped forest, mainly pines.

The second site is located on the Santa Ana River at the upper powerhouse near Running Springs (hereinafter, UPH). This site is located near the base of the San Bernardino Mountains in the Southern California Mountains ecoregion (fig. 1). The stream channel consists mostly of large boulders and cobbles. Land use is mostly undeveloped chaparral forest with willows, cottonwoods, and alders in the riparian corridor. This site is located upstream of the Seven Oaks Dam, which was under construction during the period of this study. The water quality from this site is similar to that measured at a USGS gage located near the Seven Oaks Dam, which was part of the NAWQA surface-water network.

The third site is located upstream of the Metropolitan Water District's pipeline crossing of the Santa Ana River in the inland basin (hereinafter, MWD). This site is located within the Southern and Central California Chaparral and Oak Woodlands ecoregion (fig. 1). The river at this site is a broad, shallow, sand channel constricted by bedrock outcrops on both banks. Baseflow is primarily treated wastewater supplemented with ground water forced upward by the bedrock outcrops. The riparian vegetation was primarily Arundo donax (an invasive, non-native cane), with small amounts of cattails, rushes, willows, and cottonwoods. The A. donax was removed during the second and third years of the study. Outside of the riparian corridor, land use is primarily urban. 

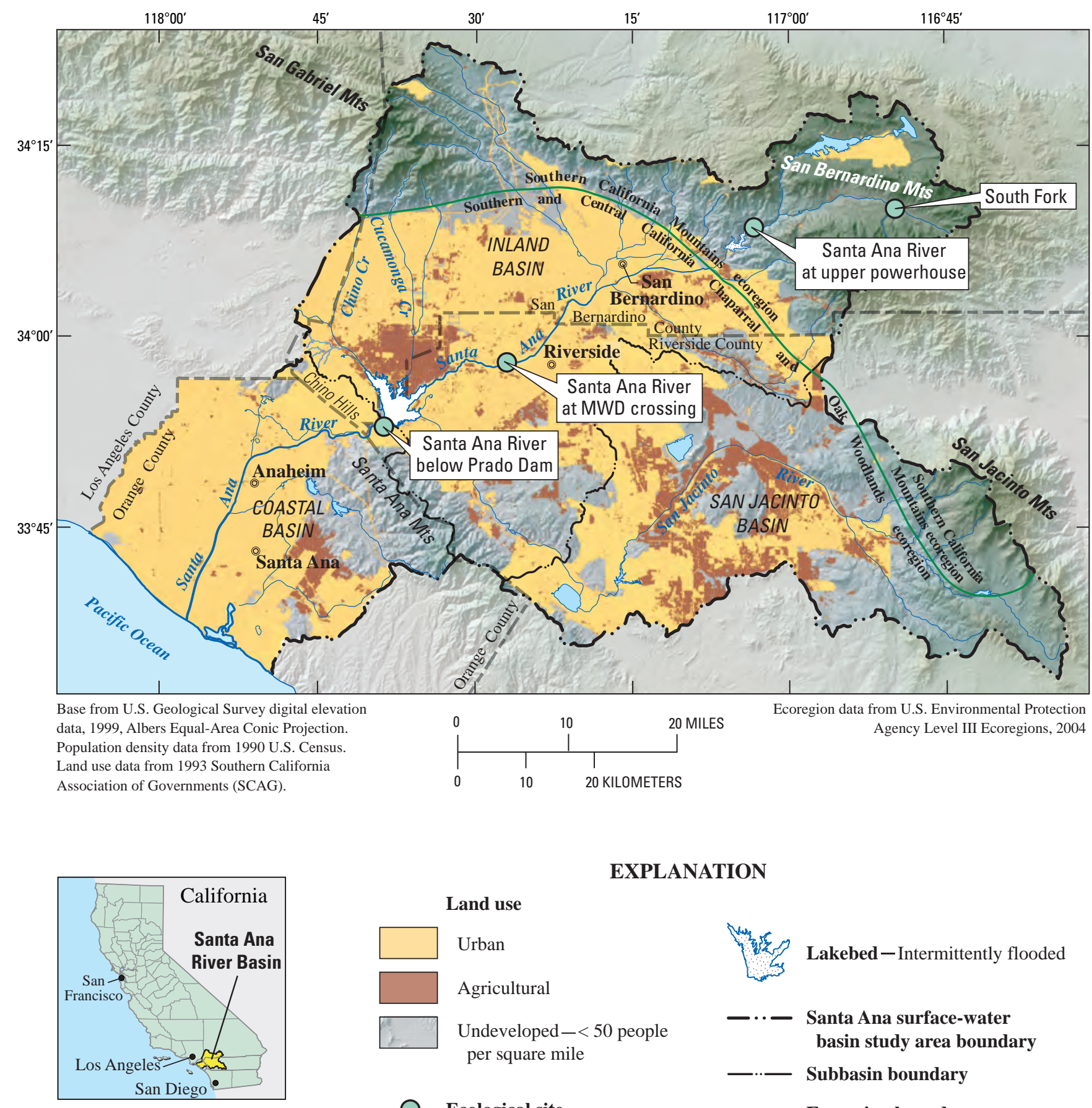

EXPLANATION
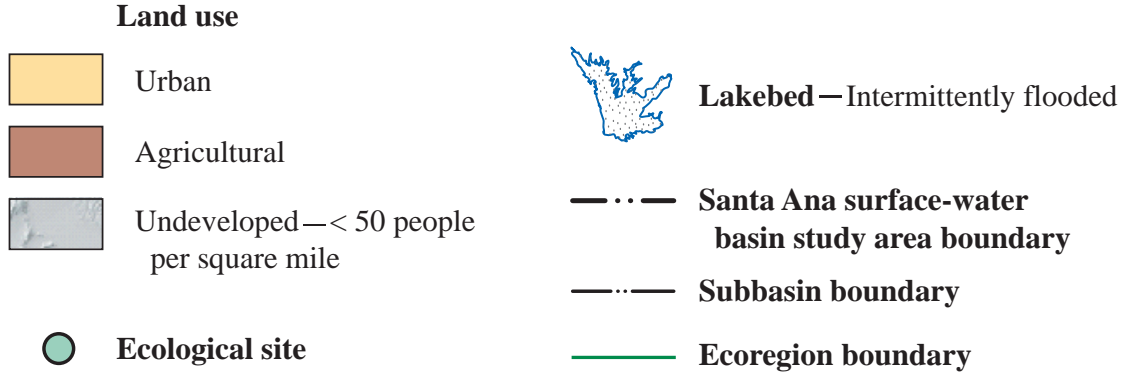

Figure 1. Location of study area, ecology sites, landuse, and ecoregions within the study area.

The fourth site is located on the Santa Ana River below Prado Dam (hereinafter, PRD). This site is also located in the Southern and Central California Chaparral and Oak Woodlands ecoregion (fig. 1). The stream channel consists of mainly cobbles and gravel. Prado Dam is operated for flood control and a permanent pool is not maintained behind the dam. Baseflow is primarily treated wastewater. Upstream of Prado Dam, a series of wetlands were constructed to act as a treatment facility for the removal of nitrate from the Santa Ana River. 
Table 1. Sites sampled for benthic algae, macroinvertebrates, fish, and habitat assessment during the summers of 1999, 2000, and 2001 in the Santa Ana River Basin, California.

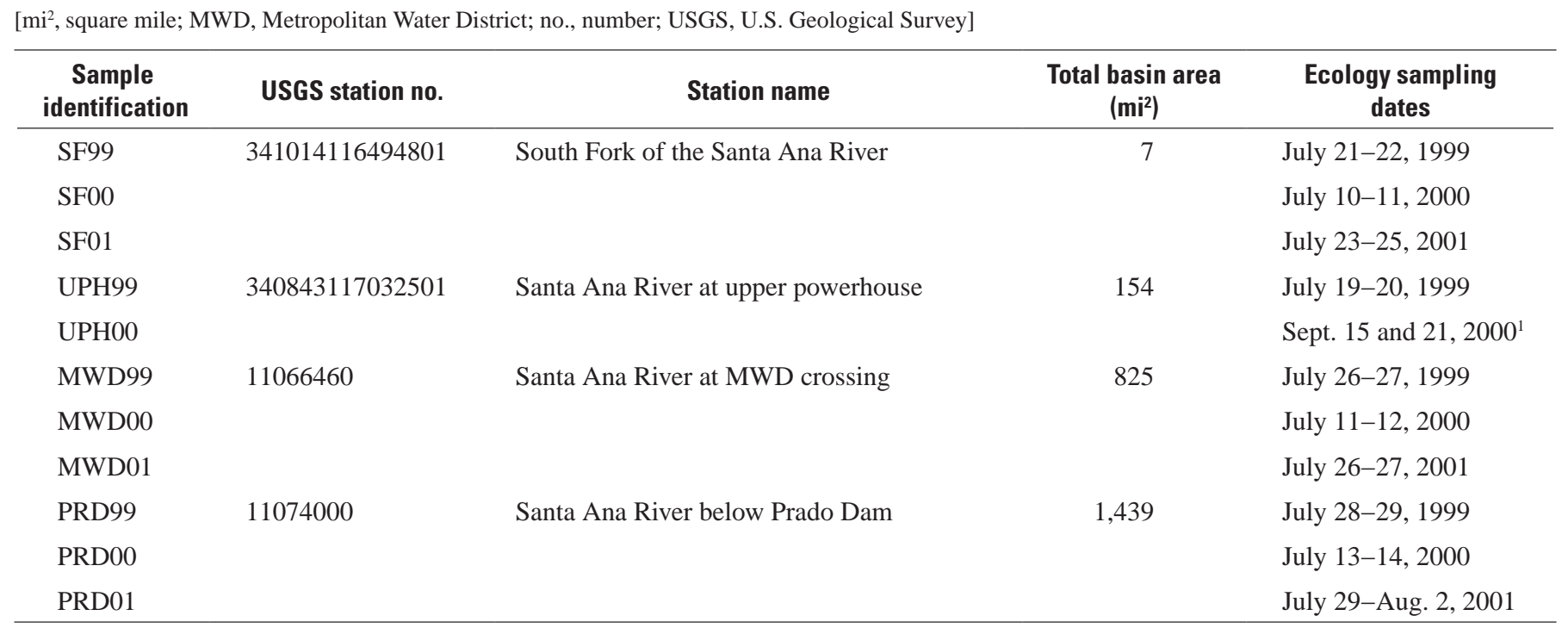

${ }^{1}$ Sampled fish and habitat only.

\section{Sample Collection}

Benthic algae, benthic macroinvertebrate, and fish community data were collected and stream habitat assessed at all sites during low-flow conditions (July to August) from 1999 to 2001 (table 1) to minimize variability resulting from seasonality. Three sites, PRD, MWD, and SF were sampled each year; one site, UPH, was sampled for macroinvertebrates and benthic algae in 1999, and fish and habitat conditions were assessed in 1999 and 2000. All sampling activity was conducted within a reach of stream defined as 20 times the mean channel width and within the range of $150 \mathrm{~m}$ to 1,000 $\mathrm{m}$ long. Habitat conditions were assessed along 11 transects in the reach as described by Fitzpatrick and others (1998). Habitat variables, such as channel width, velocity and substrate variables, and their method of collection, are listed in table 2.

Water-quality samples were collected monthly at PRD (1999-2001) and MWD (1999-2000) as part of the surfacewater fixed-site network for NAWQA (Gilliom and others, 1995; Kent and Belitz, 2004). Water-quality samples were collected monthly at SF for the first year (1999) and then quarterly for the next two years. Water-quality samples were collected at the UPH site once in August 2000, but were collected monthly at the USGS gage located about $2 \mathrm{mi}$ downstream for all three years. Only samples collected during the summer months (June-September) were used for analysis to minimize seasonal effects in variability. Water samples were analyzed for major ions, nutrients, and organic carbon at the USGS's National Water Quality Laboratory (NWQL).

Benthic algae samples were collected according to NAWQA protocols (Porter and others, 1993; Moulton and others, 2002) and are briefly summarized below. Three types of samples were collected, one qualitative and two quantitative. Qualitative benthic algae samples were collected from each microhabitat available in the reach using a variety of methods. The subsamples from each microhabitat were composited in a single container.

The quantitative benthic algae samples were collected from five representative areas in each of two different types of microhabitats: depositional-targeted habitat or DTH (which refers to the habitat in the stream where sediments are deposited) and the richest-targeted habitat or RTH (which refers to the habitat where the highest number of taxa is expected to be found). DTH benthic algae samples were collected from the surficial (5-7 mm) layer of epipelic (silt or mud) or epipsammic (sand) microhabitat at five locations within the reach. One-half of a 47-mm Petri dish was gently pushed upside down into the sediment. A stainless-steel spatula was slipped underneath the Petri dish to seal the algae subsample inside the Petri dish. The five subsamples were composited in a single container.

The RTH benthic algae samples were collected from rocks at all stream reaches, except for MWD where the sample was collected from woody snags. Rocks or snags were selected from five areas within a reach at each site. The top-rock scrape method was used except for the sample at UPH. This sample was collected from the top of rocks using the SG-92 benthic algae sampler as described by Porter and others (1993). These methods remove the benthic algae from the rock surface by scrubbing with a small brush. AT MWD, submerged woody snags ( 5 to 10 snags) were collected and scraped, and the area measured as described by Moulton and others (2002). The subsamples from each area were composited in a single container. 
Table 2. Physical habitat variables measured and method of measurement, during the summers of 1999, 2000, and 2001, at four sites in the Santa Ana River Basin, California.

[ft/s, feet per second; m, meter; mm, millimeter; na, not applicable; >, greater than]

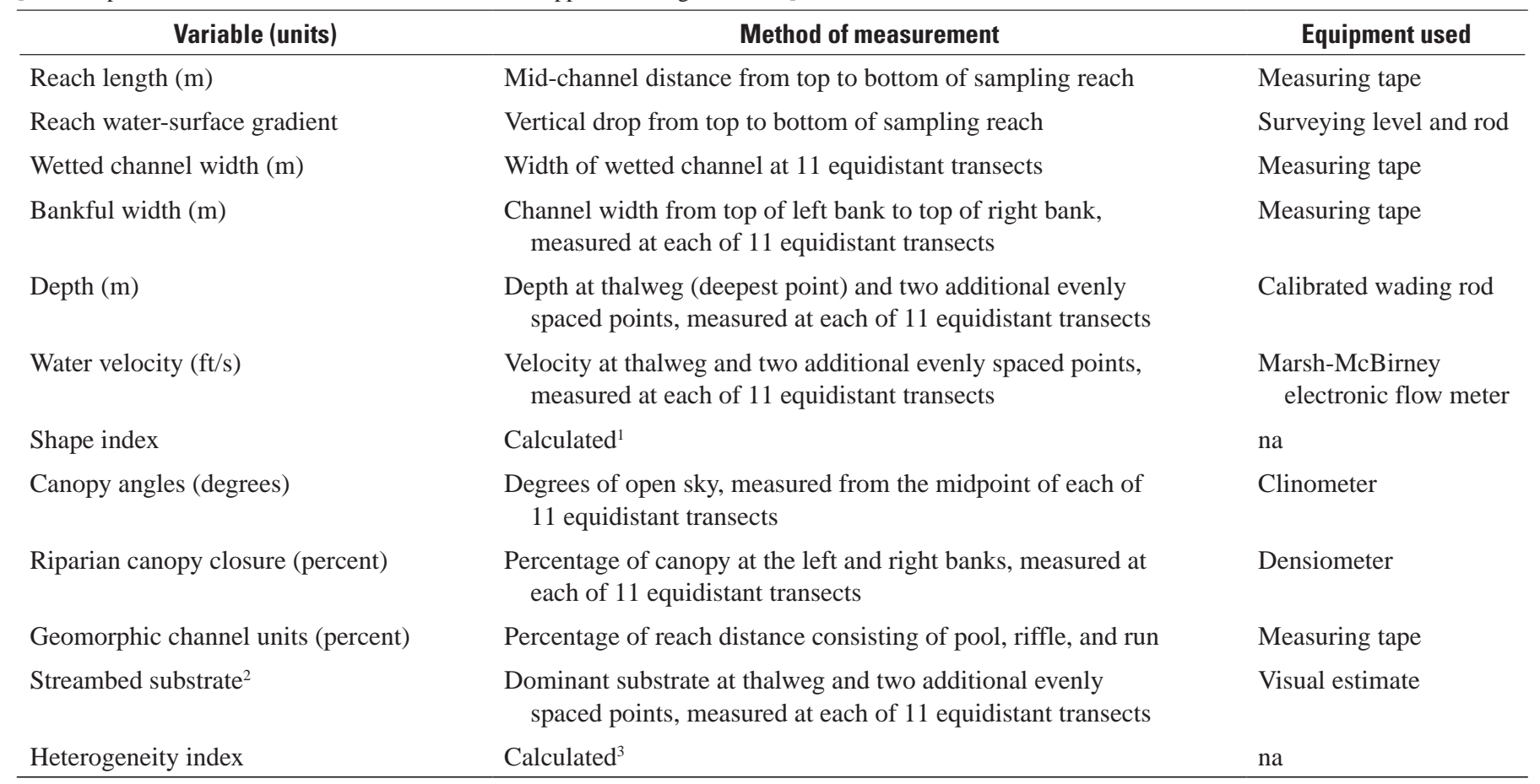

${ }^{1} \mathrm{w} /\left(\mathrm{d}^{\mathrm{d} / \mathrm{dmax}}\right)$ at 11 equidistant transects, where $\mathrm{w}=$ wetted channel width, $\mathrm{d}=$ mean depth of water along transect, and dmax = maximum depth of water along transect.

${ }^{2}$ The dominant streambed substrate was characterized as: 1 , concrete; 2 , silt, mud, or detritus; 3 , sand ( $\left.>0.063-2 \mathrm{~mm}\right) ; 4$, fine/medium gravel (>2-16 mm); 5, coarse gravel (>16-32 mm); 6, very coarse gravel (>32-64 mm); 7, small cobble (>64-128 mm); 8, large cobble (>128-256 mm); 9, small boulder (>256-512 $\mathrm{mm}) ; 10$, large boulder, irregular bedrock, irregular hardpan, or irregular artificial surface (Fitzpatrick and others, 1998).

${ }^{3}$ Geometric mean of the coefficients of variation for shape index, water velocity, riparian canopy closure, and streambed substrate.

All three types of composited benthic algae samples were preserved in 4-percent formalin. Benthic algae was identified and(or) enumerated at the National Academy of Sciences in Philadelphia, Pennsylvania, according to Charles and others (2002).

Benthic macroinvertebrate samples also were collected according to NAWQA protocols (Cuffney and others, 1993; Moulton and others, 2002). Two types of samples were collected, qualitative and semiquantitative. The qualitative multihabitat $(\mathrm{QMH})$ macroinvertebrate samples were collected using a D-frame kick net equipped with a $210-\mu \mathrm{m}$ mesh net. All habitat types present at each site were sampled.

The semiquantitative macroinvertebrate samples were RTH samples collected from five representative areas of riffles at PRD, UPH, and SF. Woody snags were used for RTH samples at MWD because riffles were not present at this site. Samples were collected using a modified slack sampler (mesh size $425 \mu \mathrm{m}$ ) with an area of $0.25 \mathrm{~m}^{2}$. These five subsamples were composited in a single container. The RTH and QMH samples were preserved with 10-percent formalin and sent to the Biological Unit of the NWQL for identification and(or) enumeration according to Moulton and others (2000).
Fish community data were collected following NAWQA protocols (Meador and others, 1993; Moulton and others, 2002). Fish were collected using a Smith-Root Model 12B backpack electrofisher. Additional fish were collected at PRD by seining. Fish were identified to species, weighed, measured, and checked for external anomalies, then returned to the stream.

\section{Data Analysis}

Habitat variables were summarized as mean and standard deviation for each year at each site. Water-quality data from samples collected from June to September in each year were summarized as mean and standard deviation. Discharge and water temperature were summarized using data from continuous monitors when possible; otherwise, discrete samples were used. Data for habitat and waterquality variables can be found in appendix 1 . To assess the annual habitat variability, coefficients of variation (CV) were calculated from the annual means of habitat variables at sites with multiyear data. 
Benthic algae and macroinvertebrate species lists were constructed using all taxa collected in all sample types. Benthic algae were identified to species in most cases. Benthic algae taxa and their densities, where applicable, can be found in appendixes 2, 3, and 4. To assess similarity in taxa among sites and years, the taxa lists for QMH, RTH, and DTH data for all sites were analyzed using an unweighted group average linkage clustering analysis of percentage of similarities. Metrics were calculated using autecological and tolerance information (Van Dam and others, 1994; Bahls, 1993; LangeBertalot, 1979). Metrics calculated from the benthic algae data can be found in appendix 5 .

Benthic macroinvertebrates were generally identified to genus. Ambiguous individuals identified at a higher taxonomic level (usually family) were distributed among the lower taxa (usually genera) in accordance with the relative abundance of each genus when more than half of the individuals were identified at the lower level. Otherwise, data were aggregated at the higher level of taxonomy. Benthic macroinvertebrates and their densities, where applicable, can be found in appendixes 6 and 7. To assess similarity in taxa among sites and years, the taxa lists for QHM, RTH, and DTH data for all sites were analyzed using an unweighted group average linkage clustering analysis of percentage of similarities. The taxa data also were summarized as biological metrics using the Invertebrate Data Analysis System (IDAS) program developed by the USGS (Cuffney, 2003). The metrics calculated from macroinvertebrate data can be found in appendix 8 .

Analysis of variance (ANOVA) was used to determine which benthic algae and macroinvertebrate metrics were significantly different $(\mathrm{P}<0.05)$ between the three sites with multiyear data. CVs were calculated for each metric that was significantly different between sites. The CV was used as a measure of temporal variance to compare sites with multiyear data. Biplots were used to examine the relationships between the CVs of benthic algae or macroinvertebrate metrics and the CVs of habitat variables. Metrics of benthic algae or macroinvertebrates that were not present at all three sites were not used in comparisons involving variance.

Fish data were summarized as relative abundance of fish species and the mean and range of the weight and length of individuals measured for each species. Appendix 9 gives the summary of fish data. Fish abundance data for all sites were analyzed using an unweighted group average linkage clustering analysis of percentage of similarities among fish samples.

\section{Variability of Benthic Algae, Macroinvertebrates, and Fish}

\section{Benthic Algae}

The cluster dendrogram of benthic algae data indicates that, for each site, the 2000 and 2001 samples were more similar to each other compared with the 1999 sample (fig. 2). This pattern was observed with QMH, RTH, and DTH samples. This may be a result of a storm that occurred in the mountains two weeks before sampling in 1999. The higher flows from the storm may have disturbed the benthic algae, especially those in depositional zones. Some benthic algae species, such as stalked diatoms (Gomphonema) (Burkholder, 1996; Kutka and Richards, 1996; Peterson, 1996) or prostrate diatoms with mucilaginous forms (Achnanthes, Cocconeis) (Goldsborough and Robinson, 1996; Hill, 1996; Kutka and Richards, 1996), recover more quickly from high flows. Higher abundances of these types of diatoms in the 1999 samples support the hypothesis that the storm was responsible for the differences.

Of the 116 metrics calculated, CVs were calculated for the 41 metrics (table 3 ) that were significantly different among sites. In general, CVs of most benthic algae metrics calculated from the RTH samples were higher at SF than at MWD or PRD (table 3). In contrast, CVs of most metrics calculated from DTH samples were lower at SF. MWD generally had the highest CVs for metrics from DTH samples. CVs of most metrics that were calculated for both RTH and DTH samples were in the same ranges $(<30,30-100,>100)$. This suggests that, in general, annual variability was not strongly related to different microhabitats (pools vs. riffles or woody snags).

Differences in annual variability may be a result of comparing the smaller SF site with the larger MWD and PRD sites (Vannote and others, 1980). Only four RTH metrics and two DTH metrics had CVs greater than 100 percent, indicating relatively low annual variation at all three sites for most benthic algae metrics. This may be a result of the study occurring during drought years (Belitz and others, 2004). 


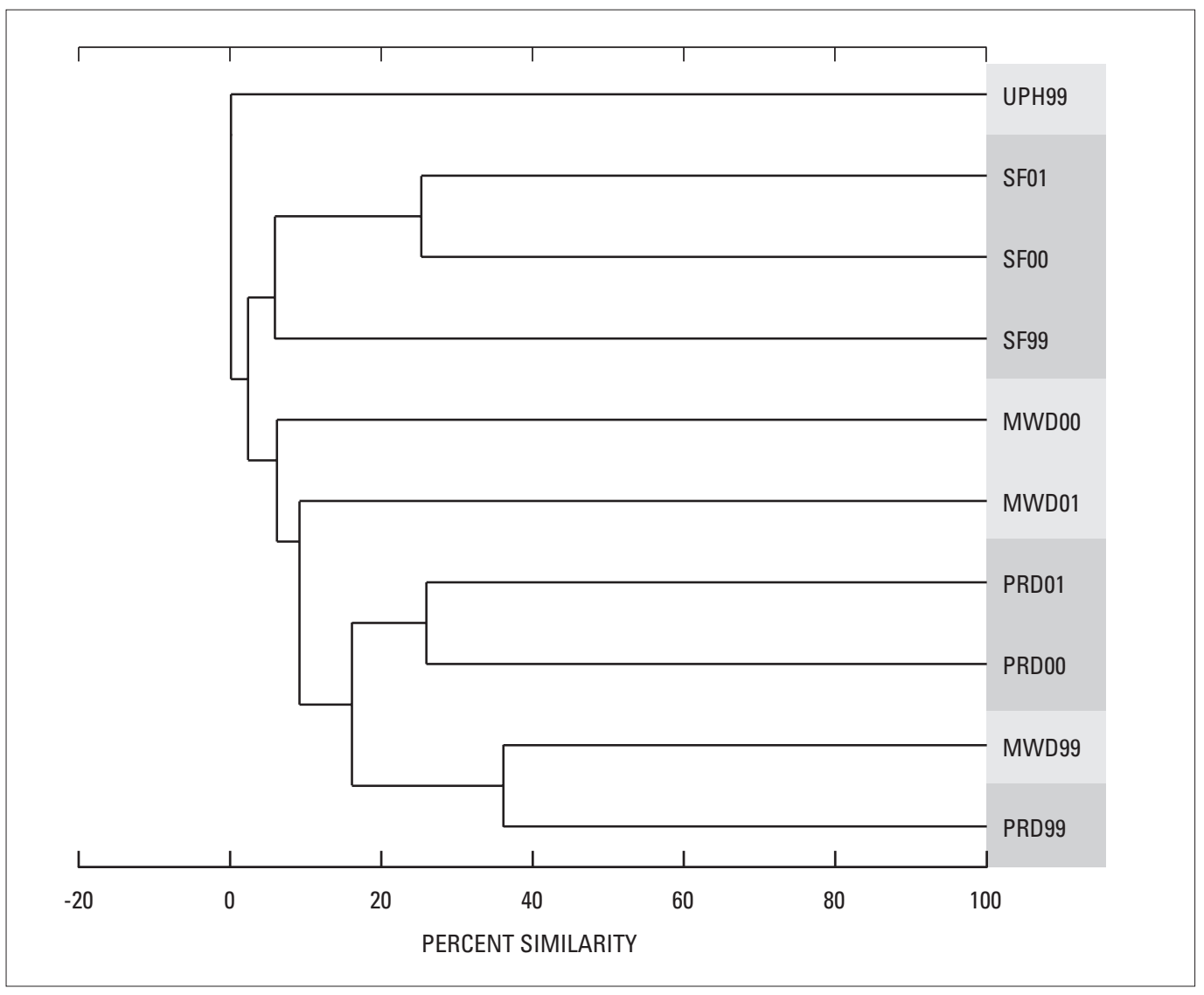

Figure 2. Cluster dendrogram showing the results of an unweighted group average linkage cluster analysis of benthic algae data collected from four sites (SF, UPH, MWD, and PRD) in the Santa Ana River Basin, California, 1999-2001.

See table 1 for sample codes.

\section{Macroinvertebrates}

The cluster dendrogram of benthic macroinvertebrate data indicates that the similarities between samples for each site is much higher than was observed in the benthic algae samples, suggesting little effect from the 1999 storm (fig. 3). Of the 167 metrics calculated for macroinvertebrates, CVs were calculated for the 65 metrics (table 4) that were significantly different among sites.

Differences in annual variation among sites were observed for both richness and abundance metrics in the Santa Ana River Basin. In general, CVs of macroinvertebrate metrics calculated from QMH samples were lower at SF than at MWD or PRD. In contrast, CVs of many metrics calculated from RTH samples were higher at SF than at MWD. PRD and SF had about the same number of high values for metrics from RTH samples; this is similar to the trend that was observed for benthic algae. MWD generally had lower CVs for RTH richness metrics than PRD, but had higher CVs for RTH abundance metrics. The higher CVs for abundance at MWD may be due to the unstable sand streambed. However, in a New Zealand study, Fowler and Death (2000) found less monthly variability at the site with the most unstable streambed substrate. They attributed this to the fewer number of species present at that site. In contrast, MWD had higher taxa richness than PRD during this study. The differences in temporal variability between this study (annual) and the New Zealand study (monthly) may have been due to the different temporal scales. Similar to algae, the CVs for almost all of the macroinvertebrate metrics were relatively low. Only six metrics, mainly abundance metrics, had CVs greater than 100 percent. This suggests that during the period of this study, annual variability in macroinvertebrate assemblages was low for all three sites. This low variability may be the result of fewer scouring events from stormflows because of the drought. 
Table 3. Coefficients of variation for benthic algae metrics that showed significant differences between sites, Santa Ana River Basin, California, 1999-2001.

[Coefficients of variation are given in percent; significance is at $\mathrm{P}<0.05$. CV, coefficient of variation ; MWD, Metropolitan Water District; QMH, qualitative habitat; RTH, richest targeted habitat; DTH, depositional habitat; nd, not detected]

\begin{tabular}{|c|c|c|c|}
\hline Metric & $\begin{array}{c}\text { CV for } \\
\text { South Fork of } \\
\text { Santa Ana River }\end{array}$ & $\begin{array}{c}\text { CV for } \\
\text { Santa Ana River } \\
\text { and MWD Crossing }\end{array}$ & $\begin{array}{c}\text { CV for } \\
\text { Santa Ana River } \\
\text { below Prado Dam }\end{array}$ \\
\hline \multicolumn{4}{|c|}{ Metrics from $\mathrm{OMH}$ data } \\
\hline Taxon richness & 3.4 & 10.6 & 9.5 \\
\hline Phylum richness & 26.6 & 21.7 & 34.6 \\
\hline \multicolumn{4}{|c|}{ Metrics from RTH data } \\
\hline Taxon richness & 13.3 & 12.5 & 7.1 \\
\hline Taxon abundance & 60.9 & 138.2 & 60.5 \\
\hline Diatom richness & 16.1 & 10.6 & 3.8 \\
\hline Blue-green algae abundance & 173.2 & 122.2 & 173.2 \\
\hline Motile diatom richness (in percent) & 12.5 & 7.9 & 11.7 \\
\hline Tolerant taxon richness (in percent) & 38.0 & 15.6 & 12.7 \\
\hline Intolerant taxon richness (in percent) & 14.5 & 55.5 & 20.9 \\
\hline Nitrogen heterotrophic diatom abundance (percent) & 69.9 & 35.5 & 37.6 \\
\hline Facultative nitrogen autotroph abundance (in percent) & 7.9 & 22.1 & 0.9 \\
\hline Halophilic diatom abundance (percent) & 127.5 & 12.1 & 22.0 \\
\hline Halophobic (fresh-brackish) diatom abundance (in percent) & 3.8 & 3.7 & 10.2 \\
\hline Sestonic diatom abundance (in percent) & nd & 37.9 & 39.7 \\
\hline Motile diatom abundance (percent) & 67.5 & 4.1 & 11.0 \\
\hline
\end{tabular}


10 Variability in Lotic Communities, Three Contrasting Stream Environments, Santa Ana River Basin, Calif., 1999-2001

Table 3. Coefficients of variation for benthic algae metrics that showed significant differences between sites, Santa Ana River Basin, California, 1999-2001.-Continued

[Coefficients of variation are given in percent; significance is at $\mathrm{P}<0.05$. CV, coefficient of variation ; MWD, Metropolitan Water District; QMH, qualitative habitat; RTH, richest targeted habitat; DTH, depositional habitat; nd, not detected]

\begin{tabular}{lcrr}
\hline \multicolumn{1}{c}{ Metric } & $\begin{array}{c}\text { CV for } \\
\text { South Fork of } \\
\text { Santa Ana River }\end{array}$ & $\begin{array}{c}\text { CV for } \\
\text { Santa Ana River } \\
\text { and MWD Crossing }\end{array}$ & $\begin{array}{c}\text { CV for } \\
\text { Santa Ana River } \\
\text { below Prado Dam }\end{array}$ \\
\hline Simpson's diversity index & Metrics from DTH data & & \\
Nitrogen heterotrophic diatom richness (in percent) & 5.5 & 9.1 & 3.8 \\
Obligative nitrogen autotrophic diatom richness (in percent) & 29.5 & 9.3 & 8.8 \\
Eutrophic diatom richness (in percent) & 25.5 & 72.2 & 51.7 \\
Halophilic diatom richness (in percent) & 9.9 & 8.8 & 4.4 \\
Alkaline diation richness (in percent) & 13.5 & 21.8 & 28.6 \\
Sestonic diatom richness (in percent) & 1.8 & 3.5 & 3.1 \\
Motile diatom richness (in percent) & 173.2 & 173.2 & 3.4 \\
Intolerant taxon richness (in percent) & 5.4 & 8.7 & 30.8 \\
Facultative nitrogen autotroph abundance (in percent) & 12.7 & 17.4 & 31.7 \\
Obligative nitrogen autotroph abundance (in percent) & 1.1 & 48.7 & 81.9 \\
Eutrophic diatom abundance (in percent) & 22.1 & 38.3 & 11.4 \\
Halophobic (fresh-brackish) diatom abundance (in percent) & 25.6 & 6.0 & 102.8 \\
Motile diatom abundance (in percent) & 80.0 & 173.2 & 11.0 \\
Bahl's tolerance index based on abundance & 22.7 & 16.1 & 5.4 \\
Siltation index & 5.7 & 15.6 & 14.4 \\
Pollution tolerance index & 11.4 & 34.6 & 6.6 \\
\hline
\end{tabular}




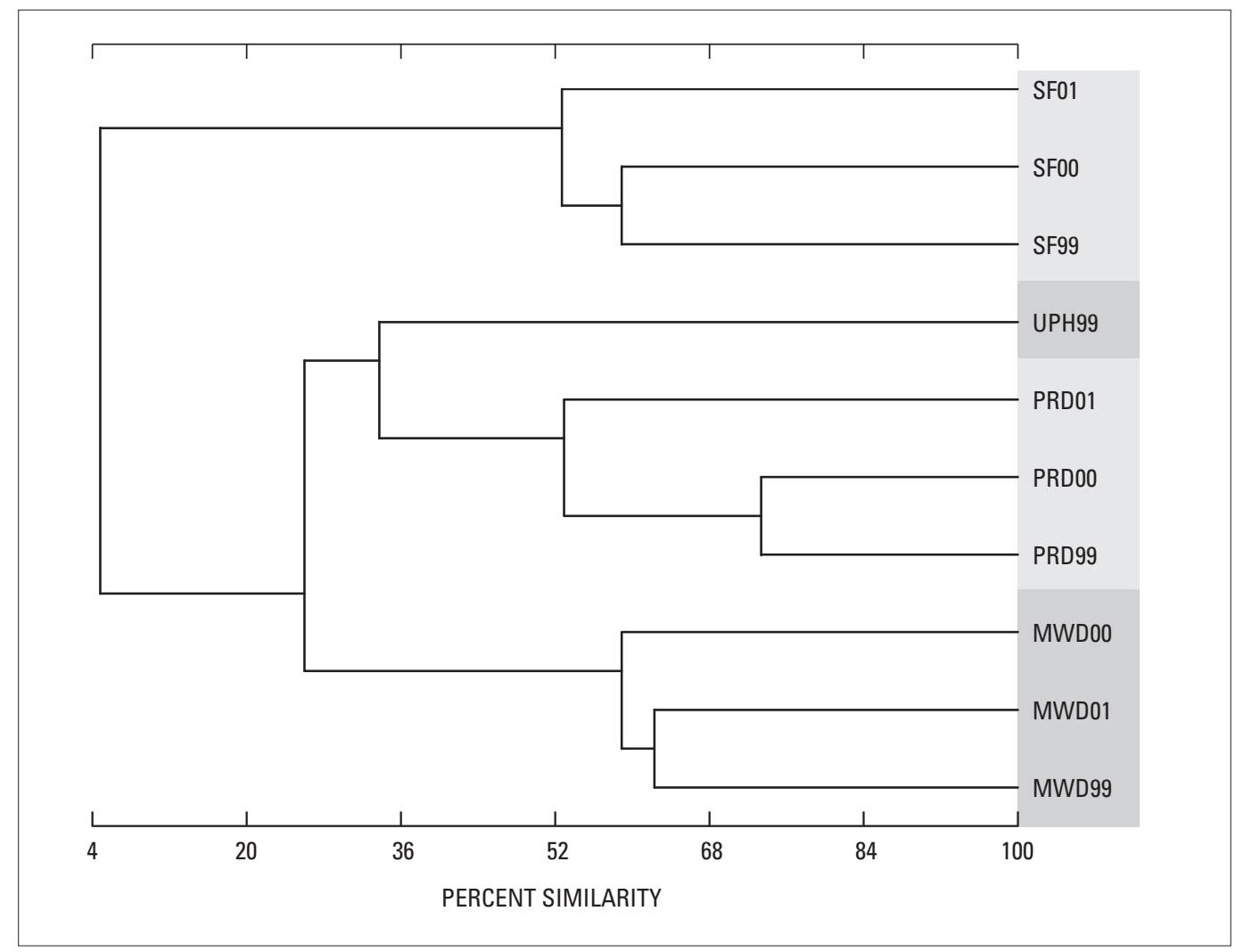

Figure 3. Cluster dendrogram showing the results of an unweighted group average linkage cluster analysis of macroinvertebrate data collected from four sites (SF, UPH, MWD, and PRD) in the Santa Ana River Basin, California, 1999-2001. See table 1 for sample codes.

The difference in CV between SF and MWD or PRD for a particular metric is generally greater than the difference in CV between MWD and PRD. This trend may be partially a result of ecoregion differences because SF is located in a different ecoregion than MWD and PRD. It is also possible that differences in stream size may also be a partial explanation for differences in variability between SF and the basin sites, as was suggested for benthic algae.

\section{Fish}

The cluster dendrogram for fish data shows that the samples from each site were generally similar, indicating low annual variability (fig. 4). However, fish samples from SF and UPH were less variable from year to year than the samples from PRD and MWD. The main reason for the low variability at SF and UPH is the low number of species (1 or 2) present compared with several species found at either MWD or PRD. For this reason, variability between sites or between years was not further investigated. More detailed information on the distribution of fish in the basin can be found in Brown and others (2005). 
Table 4. Coefficients of variation for benthic macroinvertebrate metrics that showed significant differences among three sites, Santa Ana River Basin, California, 1999-2001.

[Coefficients of variation are given in percent. Significance is at P < 0.05; CV, coefficient of variation; EPA, Environmental Protection Agency; EPT, sum of Ephemeroptera, Plecoptera, and Trichoptera; MWD, Metropolitan Water District; nd, not detected; QMH, qualitative multihabitat; RTH, richest-targeted habitat]

\begin{tabular}{|c|c|c|c|}
\hline Metric & $\begin{array}{c}\text { CV for } \\
\text { South Fork of } \\
\text { Santa Ana River }\end{array}$ & $\begin{array}{l}\text { CV for } \\
\text { Santa Ana River } \\
\text { at MWD Crossing }\end{array}$ & $\begin{array}{c}\text { CV for } \\
\text { Santa Ana River } \\
\text { below Prado Dam }\end{array}$ \\
\hline \multicolumn{4}{|c|}{ Metrics from $\mathrm{QMH}$ data } \\
\hline Taxon richness & 7.7 & 8.9 & 15.6 \\
\hline Ephemeroptera richness & 15.8 & 25.0 & 21.7 \\
\hline EPT/Chironmid richness & 12.1 & 23.3 & 11.1 \\
\hline Diptera richness & 9.2 & 7.5 & 9.4 \\
\hline Chironomid richness & 13.3 & 15.8 & 5.6 \\
\hline Nonchironomid dipteran richness & 19.9 & 10.2 & 50.0 \\
\hline Odonate richness & nd & 0.0 & 114.6 \\
\hline Ephemeroptera richness (percent) & 14.4 & 33.3 & 8.2 \\
\hline Trichoptera richness (percent) & 20.9 & 16.1 & 16.8 \\
\hline EPT richness (percent) & 3.6 & 16.6 & 4.5 \\
\hline Diptera richness (percent) & 1.8 & 11.7 & 7.2 \\
\hline Chironomid richness (percent) & 10.7 & 15.1 & 13.7 \\
\hline Noninsect richness (percent) & 7.6 & 9.6 & 6.2 \\
\hline Nonmidge dipterans and noninsect richness (percent) & 10.3 & 5.3 & 11.5 \\
\hline Oligochaete richness (percent) & 7.6 & 44.8 & 16.7 \\
\hline Scraper richness (percent) & 18.0 & 46.0 & 17.0 \\
\hline \multicolumn{4}{|c|}{ Metrics from RTH data } \\
\hline Taxon richness & 5.1 & 13.9 & 30.7 \\
\hline Ephemeroptera richness & 19.9 & 17.3 & 34.6 \\
\hline Trichoptera richness & 39.0 & 0.0 & 0.0 \\
\hline EPT richness & 12.5 & 10.8 & 15.7 \\
\hline EPT/Chironmid richness & 11.6 & 50.2 & 23.4 \\
\hline Orthoclad richness & 20.0 & 0.0 & 49.5 \\
\hline Odonate richness & nd & 0.0 & nd \\
\hline Coleoptera richness & 173.2 & 100.0 & nd \\
\hline EPT richness (percent) & 16.2 & 10.2 & 44.1 \\
\hline Odonate richness (percent) & nd & 14.7 & nd \\
\hline
\end{tabular}


Table 4. Coefficients of variation for benthic macroinvertebrate metrics that showed significant differences among three sites, Santa Ana River Basin, California, 1999-2001.-Continued

[Coefficients of variation are given in percent. Significance is at P $<0.05 ; \mathrm{CV}$, coefficient of variation; EPA, Environmental Protection Agency; EPT, sum of Ephemeroptera, Plecoptera, and Trichoptera; MWD, Metropolitan Water District; nd, not detected; QMH, qualitative multihabitat; RTH, richest-targeted habitat]

\begin{tabular}{|c|c|c|c|}
\hline Metric & $\begin{array}{c}\text { CV for } \\
\text { South Fork of } \\
\text { Santa Ana River }\end{array}$ & $\begin{array}{l}\text { CV for } \\
\text { Santa Ana River } \\
\text { at MWD Crossing }\end{array}$ & $\begin{array}{c}\text { CV for } \\
\text { Santa Ana River } \\
\text { below Prado Dam }\end{array}$ \\
\hline Noninsect richness (percent & 34.6 & 34.2 & 15.4 \\
\hline Oligochaete richness (percent) & 37.7 & 24.3 & 32.5 \\
\hline Taxon abundance & 35.0 & 19.5 & 48.1 \\
\hline Nonmidge dipterans and noninsect abundance & 3.9 & 110.9 & 46.3 \\
\hline Mollusc and crustacean abundance & 173.2 & nd & 155.4 \\
\hline Oligochaete abundance & 76.1 & 17.8 & 35.1 \\
\hline Ephemeroptera abundance (percent) & 25.1 & 41.4 & 79.3 \\
\hline $\begin{array}{l}\text { Nonmidge dipterans and noninsect abundance } \\
\text { (percent) }\end{array}$ & 19.9 & 118.7 & 41.3 \\
\hline Coleoptera abundance (percent) & 173.2 & 93.7 & nd \\
\hline Mollusc and crustacean abundance (percent) & 173.2 & nd & 166.0 \\
\hline Average EPA tolerance value based on richness & 8.5 & 5.7 & 1.6 \\
\hline EPA tolerance value (average, abundance-weighted) & 12.7 & 5.5 & 5.1 \\
\hline Percentage of most abundant taxon & 2.1 & 60.0 & 14.0 \\
\hline Percentage of two most abundant taxon & 10.2 & 32.6 & 4.3 \\
\hline Predator abundance & 33.4 & 41.4 & 45.8 \\
\hline Gatherer abundance & 41.7 & 13.6 & 42.8 \\
\hline Predator abundance (percent) & 22.7 & 48.7 & 85.9 \\
\hline Gatherer abundance (percent) & 19.8 & 27.5 & 45.3 \\
\hline Filterer abundance (percent) & 34.2 & 22.8 & 14.7 \\
\hline
\end{tabular}




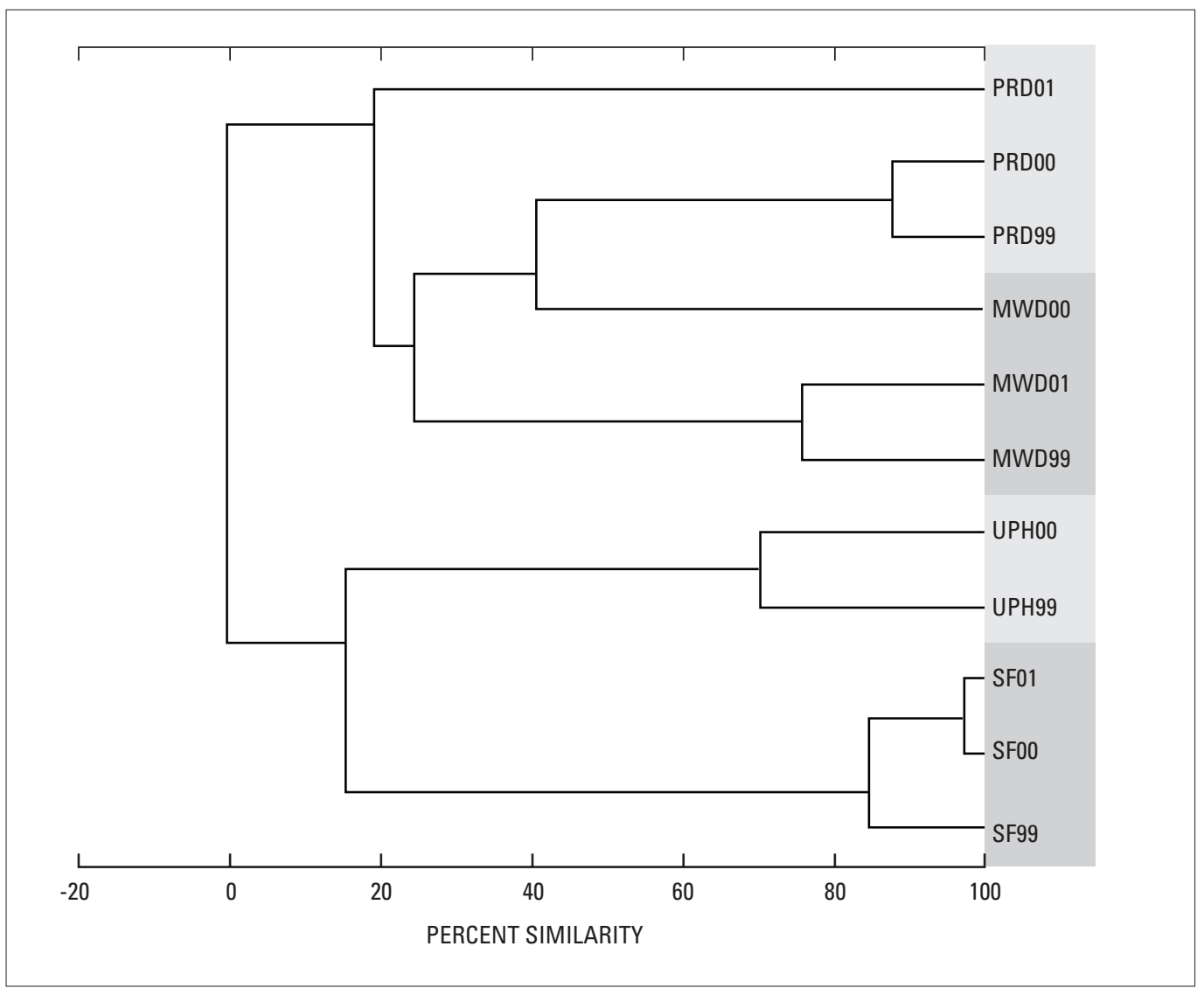

Figure 4. Cluster dendrogram showing the results of an unweighted group average linkage cluster analysis of fish data collected from four sites (SF, UPH, MWD, and PRD) in the Santa Ana River Basin, California, 1999-2001.

See table 1 for sample codes.

\section{Variability in Habitat and Water Quality}

Differences in CV between sites were observed for many habitat and water-quality variables. Annual variability was greater at SF than at the basin sites for most of the habitat and water-quality variables (table 5). SF had higher CVs for water temperature, depth, velocity, canopy angle, streambed substrate, and most water-quality variables. The CVs for these variables ranged from 10 to 105 percent. In general, the $\mathrm{CVs}$ at SF were higher than those for wilderness streams in Idaho (Robinson and others, 2000). This suggests the physical environment was more dynamic at SF than at the Idaho streams. The CV for the heterogeneity index was low (three percent) suggesting little change in channel complexity during the three years.
The multiyear CVs (table 5) for the habitat and waterquality variables, such as channel width, water temperature, and specific conductance, for PRD and MWD were generally low (frequently less than 30 percent). The CVs for riparian canopy closure and the heterogeneity index were higher at MWD. This increase was due to the removal of Arundo donax, an invasive cane species, which began during summer 2000. As a result, shading at the channel margins was greatly reduced during the last two years of the study. 
Table 5. Coefficients of variation of habitat variables for the three summers of 1999-2001 for three sites in the Santa Ana River Basin, California.

[CV, coefficient of variation; mm, millimeter; MWD, Metropolitan Water District; >, greater than]

\begin{tabular}{|c|c|c|c|}
\hline Variable & $\begin{array}{l}\text { CV for South Fork } \\
\text { of Santa Ana River }\end{array}$ & $\begin{array}{l}\text { CV for Santa Ana River } \\
\text { at MWD Crossing }\end{array}$ & $\begin{array}{l}\text { CV for Santa Ana River } \\
\text { below Prado Dam }\end{array}$ \\
\hline Discharge & 46.8 & 19.6 & 11.6 \\
\hline Water temperature & 15.4 & 5.9 & 5.2 \\
\hline Reach gradient & 0.9 & 0.0 & 40.3 \\
\hline Wetted channel width & 24.6 & 26.5 & 25.5 \\
\hline Bankfull width & 21.6 & 25.9 & 24.5 \\
\hline Depth & 44.3 & 37.9 & 39.3 \\
\hline Velocity & 100.8 & 35.2 & 63.9 \\
\hline Shape index & 17.7 & 22.2 & 7.2 \\
\hline Canopy angle & 105.4 & 7.5 & 57.0 \\
\hline Riparian canopy closure & 12.9 & 63.6 & 16.1 \\
\hline Streambed substrate $^{1}$ & 40.5 & 3.4 & 38.9 \\
\hline Run & 66.4 & 0.0 & 9.1 \\
\hline Riffle & 5.4 & 0.0 & 18.1 \\
\hline Pool & 55.4 & 0.0 & 93.0 \\
\hline Heterogeneity index ${ }^{2}$ & 3.3 & 139.5 & 40.9 \\
\hline Specific conductance & 9.8 & 2.6 & 2.0 \\
\hline Oxygen, dissolved & 8.0 & 9.5 & 4.8 \\
\hline Chloride, dissolved & 41.8 & 5.1 & 3.8 \\
\hline Nitrite + nitrate, dissolved & 15.4 & 12.1 & 7.4 \\
\hline Orthophosphate, dissolved & 66.1 & 7.2 & 15.5 \\
\hline Total organic carbon & 53.3 & 16.0 & 38.0 \\
\hline
\end{tabular}

${ }^{1}$ The streambed substrate size was characterized as: 1 , concrete; 2 , silt, mud, or detritus; 3 , sand ( $\left.>0.063-2 \mathrm{~mm}\right)$; 4, fine/medium gravel (>2-16 mm); 5, coarse gravel (>16-32 mm); 6, very coarse gravel (>32-64 mm); 7, small cobble (>64-128 mm); 8, large cobble (>128-256 mm); 9, small boulder (>256-512 mm); 10, large boulder, irregular bedrock, irregular hardpan, or irregular artificial surface (Fitzpatrick and others, 1998).

${ }^{2}$ The heterogeneity index is the geometric mean of the coefficient of variation of shape index, riparian canopy closure, stream velocity, and streambed substrate.

\section{Relationship of Biological Variability to Habitat Variability}

\section{Benthic Algae}

Many studies have shown that benthic algae assemblages are correlated to a variety of environmental variables (Leland, 1995; DeNicola, 1996; Hill and others, 2000; Sherwood and others, 2000; Kennen and Ayers, 2002). In the Santa Ana River Basin, many benthic algae metrics were associated with habitat and water-quality variables (Burton and others, 2005). However, it may be just as important to investigate the role variability may have in the interaction of benthic algae and habitat as suggested by Palmer and others (1997).

Associations of CVs of benthic algae metrics with the $\mathrm{CVs}$ of habitat variables suggest a relationship between the variability in benthic algae metrics and habitat variables (see fig. 5 for examples). Of the 41 benthic algae metrics that were significantly different among sites, the CVs of 22 showed a relationship with the $\mathrm{CV}$ of at least one habitat variable. One QMH metric, four RTH metrics, and two DTH metrics were related to the CVs of three habitat variables (table 6). The QMH metric is taxon richness. The RTH metrics included percentage richness and abundance of tolerant taxa (tolerant taxa as defined by Lange-Bertelot [1979]), percentage richness of halophobic diatoms, and percentage abundance of sestonic diatoms. The DTH metrics included percentage richness of nitrogen heterotrophic diatoms and the pollution tolerance index. The habitat variables that were related most often to benthic algae metrics included water temperature, water depth, streambed substrate, the percentage of the reach consisting of run, specific conductance, and concentrations of chloride and orthophosphate. 

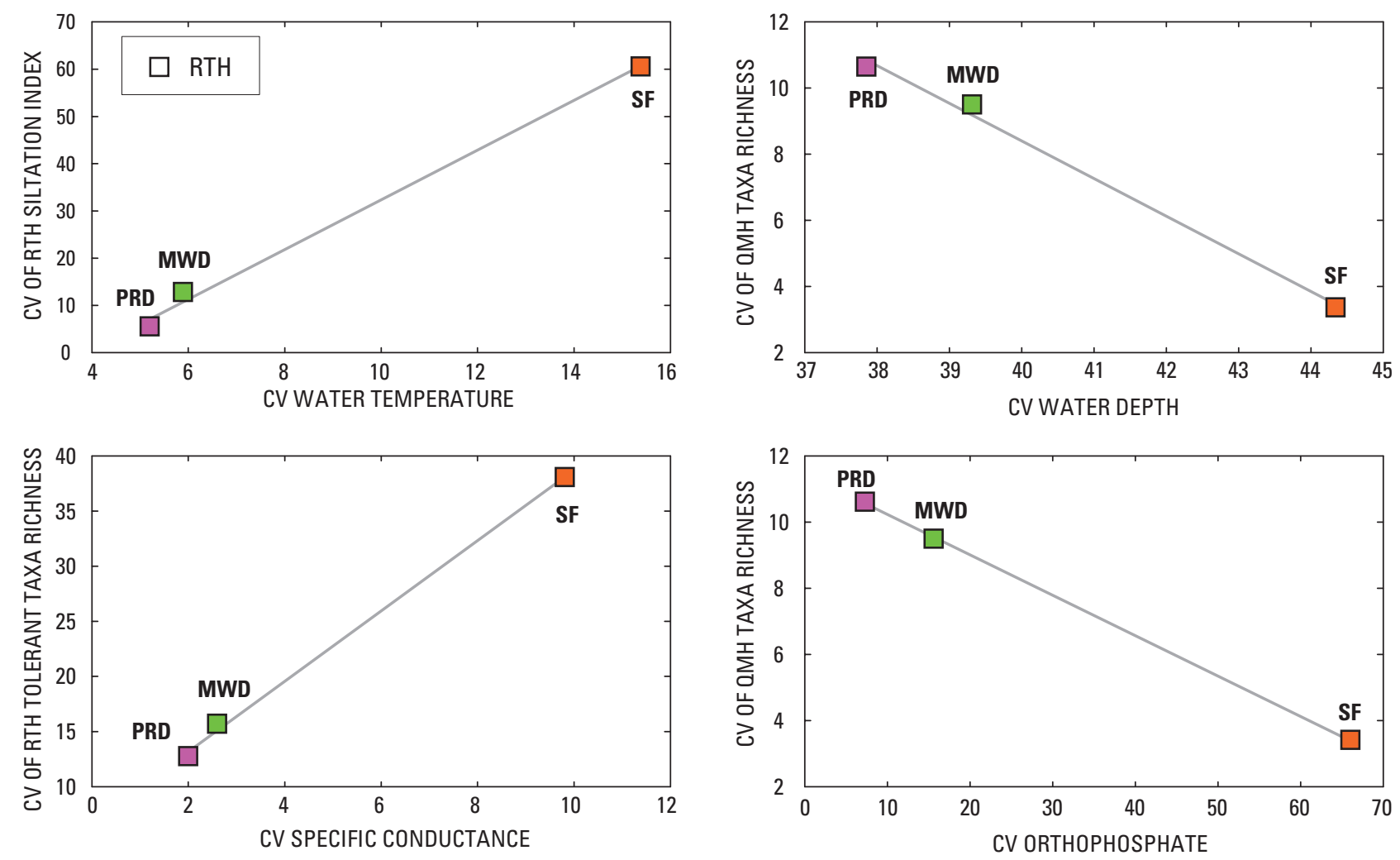

Figure 5. The relationships of the coefficient of variation of selected habitat variables to the coefficient of variation of selected benthic algae metrics collected at three sites (SF, MWD, and PRD) in the Santa Ana River Basin, California, 1999-2001.

See table 1 for sample codes and list of Abbreviations and Acronyms for definitions.

This study suggests that variability of benthic algae metrics is related to variability of habitat variables in the Santa Ana River Basin. However, ecoregion differences and the stream size also may have effects. This study included three sites with only three years of data. Additional studies that would include more sites over a longer time period would be needed to better understand the relationship between benthic algae variability and the variability of habitat. Also, this study addresses temporal variability on only an annual scale. Variability on shorter (seasonal) or longer (decadal) temporal scales may also occur.

\section{Macroinvertebrates}

Many studies have shown that macroinvertebrate assemblages are correlated to a variety of environmental variables (Brown and Brown, 1984; Barmuta, 1990; Fore and others, 1996; Leland and Fend, 1998; Brown and May, 2000). Brown and Brown (1984) showed correlations of macroinvertebrate assemblages with streambed substrate size, velocity, depth, dissolved oxygen, and water temperature. Correlations of specific conductance with macroinvertebrates assemblages have also been found (Leland and Fend, 1998; Brown and May, 2000). Higher abundance and richness of different types of functional feeding groups (FFG) have been observed in riffles (high velocity) even though more detritus (food) was available in pools (low velocity) with different substrate sizes (Barmuta, 1990). Similar relationships have also been observed in the Santa Ana River Basin (Brown and others, 2005; Burton and others, 2005). However, as with benthic algae, it may be just as important to investigate the interaction of habitat variability and variability in macroinvertebrate assemblages.

Of the 65 macroinvertebrate metrics that showed significant differences between sites, the CVs of 44 macroinvertebrate metrics showed a relationship with the $\mathrm{CV}$ of at least one habitat variable (see fig. 6 for examples). The CVs of six RTH metrics showed a relationship with the CVs of more than two habitat variables (table 7). The RTH metrics included the sum of Ephemeroptera, Plecoptera, and trichoptera (EPT) and scraper richness, percentage abundance of trichoptera and nonchironomid dipteran, and U.S. Environmental Protection Agency (EPA) tolerance (as described in Barbour and others, 1999), which is based on abundance. The habitat variables with $\mathrm{CVs}$ related to the most CVs of macroinvertebrate metrics included water temperature, water depth, riparian canopy closure, streambed substrate, percentage of the reach consisting of run, specific conductance, and orthophosphate concentrations. 
Table 6. Benthic algae metric coefficients of variation that show a positive or negative association with the coefficient of variation of at least one habitat variable.

$[(+)$, suggests a positive association with the algae metric; $(-)$, suggests a negative association with the algae metric. CV, coefficient of variation; DTH, depositional-targeted habitat; QMH, qualitative multihabitat; RTH, richest-targeted habitat; mm, millimeter; nd, not detected]

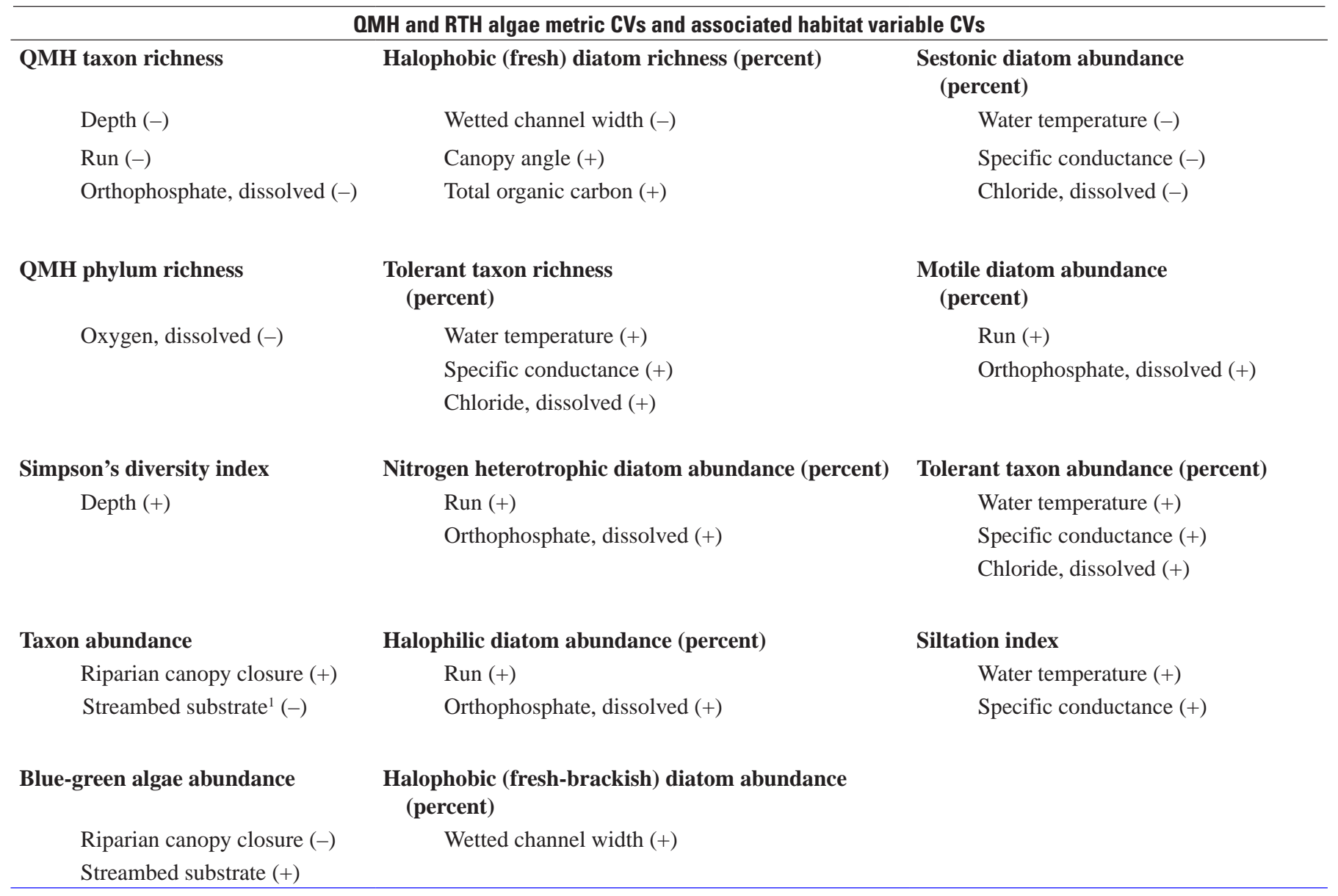

DTH algae metric CVs and associated habitat variable CVs

\begin{tabular}{|c|c|c|}
\hline $\begin{array}{l}\text { Nitrogen heterophic diatom } \\
\text { richness (percent) }\end{array}$ & Sestonic diatom richness (percent) & Siltation index \\
\hline Water temperature $(+)$ & Reach gradient (-) & Riparian canopy closure \\
\hline \multicolumn{3}{|l|}{ Specific conductance $(+)$} \\
\hline \multicolumn{3}{|l|}{ Chloride, dissolved (+) } \\
\hline $\begin{array}{l}\text { Obligative nitrogen autotrophic } \\
\text { diatom richness (percent) }\end{array}$ & Facultative nitrogen autotroph abundance (percent) & Pollution tolerance index \\
\hline Velocity $(-)$ & Bankfull width (+) & Shape index $(+)$ \\
\hline \multirow[t]{2}{*}{ Canopy angle $(-)$} & & Riffle (-) \\
\hline & & Oxygen, dissolved (+) \\
\hline
\end{tabular}

Alkaline diation richness (percent) Halophobic (fresh-brackish) diatom abundance (percent)

Depth (-) Heterogeneity index ${ }^{2}(+)$

${ }^{1}$ The streambed substrate size was characterized as: 1 , concrete; 2 , silt, mud, or detritus; 3 , sand ( $\left.>0.063-2 \mathrm{~mm}\right) ; 4$, fine/medium gravel (>2-16 mm); 5, coarse gravel (>16-32 mm); 6, very coarse gravel (>32-64 mm); 7, small cobble (>64-128 mm); 8, large cobble (>128-256 mm); 9, small boulder (>256-512 mm); 10, large boulder, irregular bedrock, irregular hardpan, or irregular artificial surface (Fitzpatrick and others, 1998).

${ }^{2}$ The heterogenieity index is the geometric mean of the coefficient of variation of the shape index, the riparian closure, stream velocity, and streambed substrate. 

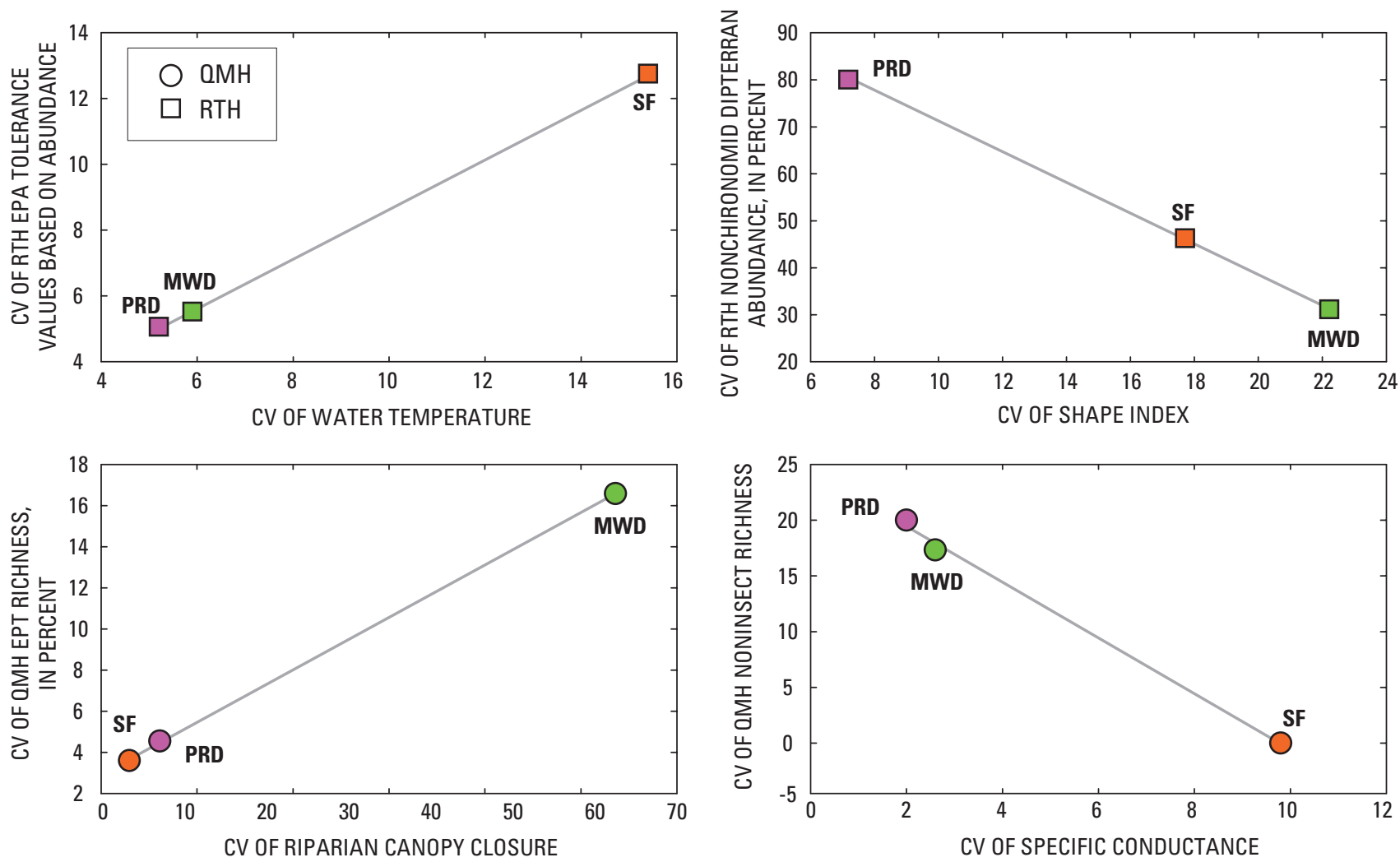

Figure 6. The relationships of the coefficient of variation of selected habitat variables to the coefficient of variation of selected macroinvertebrate metrics collected at three sites. (SF, MWD, and PRD) in the Santa Ana River Basin, California, 1999-2001.

CV, coefficient of variation; EPA, U.S. Environmental Protection Agency; EPT, sum of Ephemeroptera, Plecoptera, and Trichoptera; RTH, richest-targeted habitat; DTH, depositional-targeted habitat; $\mathrm{OMH}$, qualitative multihabitat.

This study suggests that annual variability of habitat variables may be related to variability of macroinvertebrate metrics in the Santa Ana River Basin. However, it is also possible that ecoregion differences and stream size may have effects on macroinvertebrate variability. As noted previously, this study included three sites with only three years of data. Additional studies would be needed to better define this relationship. More sites over a longer time period are necessary to better understand the role of variability in the relationship between habitat and macroinvertebrates and at what scales these relationships exist. Studies using individual taxa, in addition to metrics, may need to be investigated to determine some of these relationships.

\section{Implications of Variability to Biomonitoring or Water Management Issues}

Aquatic ecosystems are naturally dynamic and vary over space and time. This report shows the annual variability for habitat, water quality, and biological communities. The differences in biological communities at small and large temporal scales need to be documented in the Santa Ana River to determine if observed changes in communities are within the range of natural variability or if human activities may be the cause. This information would be important for any biomonitoring program that evaluates whether the ecosystem is improving or degrading in quality.

The effects of physical variability on aquatic life are important considerations for water management and stream improvement projects. Biological communities are composed of species adapted for some measure of variability in the hydrologic system during their life cycle. However, large differences in flow, such as floods, at the wrong time can have a detrimental effect on aquatic organisms. Streams with homogeneous habitat will not provide preferred habitat or necessary food resources for some species. Concrete channels with shallow flow may be highly productive for algae and can reduce nitrate concentrations (Kent and others, 2005), but such channels usually provide habitat for few species of algae, macroinvertebrates, or fish (Brown and others, 2005; Burton and others, 2005). 
Table 7. Macroinvertebrate metric coefficient of variations that show a positive or negative association with the coefficient of variation of at least one habitat variable.

$[(+)$, suggests a positive association with the macroinvertebrate metric; $(-)$, suggests a negative association with the macroinvertebrate metric. CV, coefficient of variation; EPA, Environmental Protection Agency; EPT, sum of Ephemeroptera, Plecoptera, and Trichoptera; QMH, qualitative multihabitat; RTH, richesttargeted habitat; mm, milimeter]

\section{OMH macroinvertebrate metric CVs and associated habitat variable CVs}

\begin{tabular}{|c|c|c|}
\hline Ephemeroptera richness & $\begin{array}{l}\text { Nonmidge dipterans and noninsect } \\
\text { richness }\end{array}$ & Chironomid richness (percent) \\
\hline \multirow[t]{2}{*}{ Bankfull width (+) } & Shape index $(-)$ & Bankfull width $(+)$ \\
\hline & Riffle (+) & \\
\hline Trichoptera richness & Odonate richness & Noninsect richness (percent) \\
\hline Reach gradient (-) & Reach gradient $(+)$ & Pool $(-)$ \\
\hline Chironomid richness & Trichoptera richness (percent) & Oligochaete richness (percent) \\
\hline Shape index $(+)$ & Run $(+)$ & Heterogeneity index ${ }^{2}(+)$ \\
\hline Riffle (-) & Orthophosphate, dissolved (+) & \\
\hline Nonchironomid dipteran richness & EPT richness (percent) & $\begin{array}{l}\text { EPA tolerance value (average, richness- } \\
\text { weighted) }\end{array}$ \\
\hline Noninsect richness & Diptera richness (percent) & Scraper richness (percent) \\
\hline Water temperature $(-)$ & Velocity $(-)$ & Streambed substrate $(-)$ \\
\hline Specific conductance $(-)$ & Canopy angle (-) & \\
\hline
\end{tabular}

RTH macroinvertebrate metric CVs and associated habitat variable CVs

Taxon richness
Nitrite + nitrate, dissolved
Trichoptera richness
Water temperature $(+)$
Specific conductance $(+)$
Chloride, dissolved $(+)$

Coleoptera richness

Nitrite + nitrate, dissolved $(+)$

Noninsect richness (percent)

Reach gradient (-)
Taxon abundance

Pool (+)

Nonchironomid diptera abundance Bankfull width (-)
EPT richness

Shape index (-)

Riffle (+)

Oxygen, dissolved (-)

\section{EPT/Chironmid richness}

Heterogeneity index (+)
Odonate richness (percent)

$$
\text { Riparian canopy closure (+) }
$$

Streambed substrate (-)

Oligochaete richness (percent)

Wetted channel width (-)

Total organic carbon (+)
Nonmidge dipterans and noninsect abundance

Wetted channel width (+)

Total organic carbon (-)

Mollusc and crustacean abundance

Riparian canopy closure (-)

Streambed substrate $(+)$ 
Table 7. Macroinvertebrate metric coefficient of variations that show a positive or negative association with the coefficient of variation of at least one habitat variable.-Continued

$[(+)$, suggests a positive association with the macroinvertebrate metric; $(-)$, suggests a negative association with the macroinvertebrate metric. CV, coefficient of variation; EPA, Environmental Protection Agency; EPT, sum of Ephemeroptera, Plecoptera, and Trichoptera; QMH, qualitative multihabitat; RTH, richesttargeted habitat; $\mathrm{mm}$, milimeter]

\section{Oligochaete abundance \\ Bankfull width (-) \\ Depth (+)}

Trichoptera abundance (percent)

Shape index (+)

Riffle (-)

Oxygen, dissolved (+)

Tanytarsinii abundance (percent)

Heterogeneity index (+)

\section{Nonchironomid dipteran abundance} (percent)

Shape index (-)

Riffle (+)

Oxygen, dissolved (-)

Nonmidge dipterans and noninsect abundance (percent)

Heterogeneity index (+)

Coleoptera abundance (percent)

Nitrite + nitrate, dissolved $(+)$
EPA tolerance value (average, richnessweighted)

Nitrite + nitrate, dissolved (+)
Scraper richness

Water temperature (-)

Specific conductance (-)

Chloride, dissolved (-)

Shredder richness

Pool (-)
EPA tolerance value (average, abundance- Filterer richness (percent) weighted)
Water temperature $(+)$
Specific conductance $(+)$
Water temperature $(+)$
Chloride, dissolved (+)

Chloride, dissolved $(+)$
Percentage of most abundant taxon

Heterogeneity index (+)
Scraper richness (percent)

Riparian canopy closure (+)

Streambed substrate (-)
Predator richness

Pool (+)

\section{Gatherer abundance}

Streambed substrate (+)
Predator abundance (percent)

Nitrite + nitrate, dissolved (-)

${ }^{1}$ The streambed substrate size was characterized as: 1 , concrete; 2 , silt, mud, or detritus; 3 , sand (>0.063-2 mm); 4, fine/medium gravel ( $>2-16$ mm); 5, coarse gravel (>16-32 mm); 6, very coarse gravel (>32-64 mm); 7, small cobble (>64-128 mm); 8, large cobble (>128-256 mm); 9, small boulder (>256-512 mm); 10, large boulder, irregular bedrock, irregular hardpan, or irregular artificial surface (Fitzpatrick and others, 1998).

${ }^{2}$ The heterogenieity index is the geometric mean of the coefficient of variation of the shape index, the riparian closure, stream velocity, and streambed substrate. 


\section{Summary and Conclusions}

Understanding variability of natural assemblages is important in the interpretation of any ecological study. Data from an ecological study conducted during the summers 1999-2001 by the Santa Ana River Basin study unit of the USGS's NAWQA program were used to do a preliminary assessment of variability in the Santa Ana River Basin. Twenty-two habitat and water-quality variables were measured at three sites in the basin. The appendixes list the 233 taxa of benthic algae, 144 taxa of macroinvertebrates, and 16 taxa of fish that were collected. Significant differences in benthic algae metrics, macroinvertebrate metrics, and fish assemblages and variability were observed among the three sites. Annual variability in most habitat and water-quality variables was higher at the alpine site located in the mountains (SF) than at the basin sites (MWD and PRD). In general, annual variability in RTH benthic algae metrics was higher at SF, but annual variability in DTH metrics was lower. Annual variability in RTH macroinvertebrate metrics was higher at SF and PRD than at MWD. In contrast, annual variability in QMH macroinvertebrate metrics was lower at SF than at MWD or PRD. Annual variability in fish assemblages was higher at MWD and PRD primarily because of the higher number of species present at these sites. The CVs of seven benthic algae metrics and six macroinvertebrate metrics were correlated to the CVs of many of the habitat variables measured.

The variability of physiochemical variables is likely to have a role in structuring the annual variability of aquatic communities in the Santa Ana River Basin. However, some of the differences observed in habitat and aquatic communities between sites may be attributed to differences in ecoregions or stream size rather than variability. Although the data collected have a limited temporal scope, this report provides valuable baseline data on the variability of biological communities in the Santa Ana River Basin. Additional sampling at more sites over several years to address variability would be needed to better understand the variability in the composition of biological communities in the Santa Ana River Basin.

\section{References}

Andrew, N.R.; Rodgerson, Louise; and Dunlop, M., 2003, Variation in invertebrate-bryophyte community structure at different spatial scales along altitudinal gradients: Journal of Biogeography, v. 30, p. 731-746.

Bahls, L.L., 1993, Benthic algae bioassessment methods for Montana streams (Revised January 1993): Helena, Montana, Department of Health and Environmental Sciences, Water Quality Bureau.
Barbour, M.T.; Gerritsen, J.; Snyder, B.D.; and Stribling, J.B., 1999, Rapid bioassessment protocols for use in streams and wadeable rivers: periphyton, benthic macroinvertebrates and fish, (2nd ed.): U.S. Environmental Protection Agency Report EPA 841-B-99-02, 226 p.

Barmuta, L.A., 1990, Interaction between the effects of substratum, velocity, and location on stream benthos-an experiment: Australian Journal of Marine and Freshwater Research, v. 41, p. 557-573.

Belitz, Kenneth; Hamlin, S.N.; Burton, C.A.; Kent, R.H.; Fay, R.G.; and Johnson, Tyler; 2004, Water quality in the Santa Ana Basin, California, 1999-2001: U.S. Geological Survey Circular 1238, $37 \mathrm{p}$.

Brown, A.V., and Brown, K.B., 1984. Distribution of insects within riffles of streams: Freshwater Invertebrate Biology, v. 3 , no. 1 , p. 2-11.

Brown, B.L., 2003, Spatial heterogeneity reduces temporal variability in stream insect communities: Ecology Letters, v. 6, p. 316-325.

Brown, L.R.; Burton, C.A.; and Belitz, Kenneth; 2005, Aquatic assemblages of the highly urbanized Santa Ana River Basin, California, in Brown, L.R., Gray, R.H., Hughes, R.M, and Meador, M.R., eds., Effects of urbanization on stream ecosystems: Bethesda, Maryland, American Fisheries Society, Symposium 47, p. 263-287.

Brown, L.R., and May, J.T., 2000, Macroinvertebrate assemblages on woody debris and their relations with environmental variables in the lower Sacramento and San Joaquin river drainages, California: Environmental Monitoring and Assessment v. 64, p. 311-329.

Burkholder, J.M., 1996, Interactions of benthic algae with their substrata, in Stevenson, R.J., Bothwell, M.L., and Lowe, R.L., eds., Algal ecology-freshwater benthic ecosystems: San Diego, Calif., Academic Press, p. 253-297.

Burton, C.A.; Brown, L.R.; and Belitz, Kenneth; 2005, Assessing water source and channel type as factors affecting benthic macroinvertebrate and benthic algae assemblages in the highly urbanized Santa Ana River basin, California. in Brown, L.R., Gray, R.H., Hughes, R.M., and Meador, M.R., eds., Effects of urbanization on stream ecosystems: Bethesda, Maryland, American Fisheries Society, Symposium 47, p. 239-262.

Cardinale, B.J.; Palmer, M.A.; Swan, C.M.; Brooks, Shane; and Poff, N.L.; 2002, The influence of substrate heterogeneity on biofilm metabolism in stream ecosystem: Ecology, v. 83, no. 2, p 412-422. 
Charles, D.F.; Knowles, Cynthia; and Davis, R.S., eds., 2002, Protocols for the analysis of algal samples collected as part of the U.S. Geological Survey National Water-Quality Assessment program: Philadelphia, Pa., Patrick Center for Environmental Research Report No. 02-06, Academy of Natural Sciences, 124 p.

Cuffney, T.F., 2003, User's manual for the National WaterQuality Assessment program invertebrate data analysis system (IDAS) Software: version 3: U.S. Geological Survey Open-File Report 03-172, 103 p.

Cuffney, T.F.; Gurtz, M.E.; and Meador, M.R., 1993, Methods for collecting benthic invertebrate samples as part of the National Water-Quality Assessment program: U.S. Geological Survey Open-File Report 93-406, 66 p.

DeNicola, D.M., 1996, Benthic algae responses to temperature at different ecological levels in Stevenson, R.J., Bothwell, M.L., and Lowe, R.L., eds., Algal ecology_freshwater benthic ecosystems: San Diego, Calif., Academic Press, p. 149-181.

Downes, B.J.; Lake, P.S.; and Schreiber, E.S.G., 1993, Spatial variation in the distribution of stream invertebratesimplications of patchiness for models of community organization: Freshwater Biology, v. 30, p. 119-132.

Fayram, A.H.; Miller, M.A.; and Colby, A.C., 2005, Effects of stream order and ecoregion on variability in coldwater fish index of biotic integrity scores within streams in Wisconsin: Journal of Freshwater Ecology, v. 20, no. 1, p. 17-25.

Fitzpatrick, F.A.; Waite, I.R.; D’Arconte, P.J.; Meador, M.R.; Maupin, M.A.; and Gurtz, M.E., 1998, Revised methods for characterizing stream habitat in the National Water-Quality Assessment program: U.S. Geological Survey Water Resources Investigations Report 98-4052, 67 p.

Fore, L.S.; Karr, J.R.; and Wisseman, R.W., 1996, Assessing invertebrate responses to human activities-evaluating alternative approaches: Journal of the North American Benthological Society, v. 15, p. 212-231.

Fowler, R.T., and Death, R.G., 2000, Effects of channel morphology on temporal variation in invertebrate community structure in two North Island, New Zealand rivers: New Zealand Journal of Marine and Freshwater Research, v. 34, p. 231-240.

Gilliom, R.J.; Alley, W.M.; and Gurtz, M.E., 1995, Design of the National Water-Quality Assessment programoccurrence and distribution of water-quality condition: U.S. Geological Survey Circular 1112, 33 p.

Goldsborough, L.G., and Robinson, G.G.C., 1996, Pattern in wetlands, in Stevenson, R.J., Bothwell, M.L., and Lowe, R.L., eds., Algal ecology-freshwater benthic ecosystems: San Diego, Calif., Academic Press, p. 77-117.
Heino, Jani; Muotka, Timo; and Paavola, Riku; 2003, Determinants of macroinvertebrate diversity in headwater streams-regional and local influences: Journal of Animal Ecology, v. 72, p. 425-434.

Herbert, M.E., and Gelwick, F.P., 2003, Spatial variation of headwater fish assemblages explained by hydrologic variability and upstream effects of impoundment: Copeia, v. 2003, no. 2 , p. 273-284.

Hill, B.H.; Herlihy, A.T.; Kaufmann, P.R.; Stevenson, R.J.; McCormick, F.H.; and Johnson, C.B., 2000, Use of benthic algae data as an index of biotic integrity: Journal of the North American Benthological Society v. 19, p. 50-67.

Hill, Walker, 1996, Effects of light, in Stevenson, R.J., Bothwell, M.L., and Lowe, R.L., eds., Algal ecologyfreshwater benthic ecosystems: San Diego, Calif., Academic Press, p. 121-148.

Kennen, J.G., and Ayers, M.A., 2002, Relation of environmental characteristics to the composition of aquatic assemblages along a gradient of urban land use in New Jersey, 1996-98: U.S. Geological Survey Water-Resources Investigations Report 02-4069, 77 p.

Kent R.H., and Belitz, Kenneth, 2004, Concentrations of dissolved solids and nutrients in water sources and selected streams of the Santa Ana Basin, California, October 1998September 2001: U.S. Geological Survey Water-Resources Investigations Report 03-4326, 61 .

Kent, R.H.; Belitz, Kenneth; and Burton, C.A.; 2005 , Algal productivity and nitrate assimilation in an effluent dominated concrete lined stream: Journal of the American Water Resources Association, v. 41, no. 5, p. 1109-1128.

Koel, T.M., and Peterka, J.J., 2003, Stream fish communities and environmental correlates in the Red River of the North, Minnesota and North Dakota: Environmental Biology of Fishes, v. 67, no. 2, p.137-155.

Kutka, F.J., and Richards, Carl, 1996, Relating diatom assemblage structure to stream habitat quality: Journal of the North American Benthological Society, v.15, no. 4, p. 469-480.

Lange-Bertalot, Horst, 1979, Pollution tolerance of diatoms as a criterion for water quality estimation. Nova Hedwigia, v. 64, p. 285-304.

Leland, H.V., 1995, Distribution of phytobenthos in the Yakima River Basin, Washington, in Relation to geology, land use, and other environmental factors: Canadian Journal of Fisheries and Aquatic Sciences, v. 52, p. 1108-1129.

Leland, H.V., and Fend, S.V., 1998, Benthic invertebrate distributions in the San Joaquin River, California, in relation to physical and chemical factors: Canadian Journal of Fisheries and Aquatic Sciences v. 55, p. 1051-1067. 
Li, Judith; Herlihy, Alan; Gerth, William; Kaufman, Philip; Gregory, Stanley; Urquhart, Scott; and Larsen, D.P., 2001, Variability in stream macroinvertebrates at multiple spatial scales: Freshwater Biology, v. 46, p. 87-97.

Meador, M.R.; Cuffney, T.F.; and Gurtz, M.E., 1993, Methods for sampling fish communities as part of the National Water-Quality Assessment program: U.S. Geological Survey Open-File Report 93-104, 40 p.

Mendez, G.O., and Belitz, Kenneth, 2002, Identifying sources of baseflow in the Santa Ana River, California, in Kenny, J.F., ed., Ground water/surface water interactionsProceedings of the American Water Resources Association 2002 summer specialty conference, Keystone, Colo.: TPS02-2, p. 567-572.

Moulton, S.R., II; Carter, J.L.; Grotheer, S.A.; Cuffney, T.F.; and Short, T.M., 2000, Methods of analysis by the U.S. Geological Survey National Water Quality Laboratoryprocessing, taxonomy, and quality control of benthic macroinvertebrate samples: U.S. Geological Survey OpenFile Report 00-212, 49 p.

Moulton, S.R., II; Kennen, J.G.; Goldstein, R.M.; and Hambrook, J.A., 2002, Revised protocols for sampling algal, invertebrate, and fish communities as part of the National Water-Quality Assessment program: U.S. Geological Survey Open-File Report 02-150, 75 p.

Needham, P.R., and Usinger, R.L., 1956, Variability in the macrofauna of a single riffle in Prosser Creek, California, as indicated by the surber sampler: Hilgardia, v. 24, p. 383-409.

Palmer, M.A.; Hakenkamp, C.C.; and Nelson-Baker, Karen, 1997, Ecological heterogeneity in streams-why variance matters: Journal of the North American Benthological Society, v. 16, p. 189-202.

Palmer, M.A.; Swan, C.M.; Nelson, Karen; Silver, Pamela; and Alvestad, Rachel, 2000, Streambed landscapesevidence that stream invertebrates respond to the type and spatial arrangement of patches: Landscape Ecology, v. 15, p. 563-576.

Peterson, C.G., 1996, Response of benthic algal communities to natural physical disturbance, in Stevenson, R.J., Bothwell, M.L., and Lowe, R.L., eds., Algal ecologyfreshwater benthic ecosystems: San Diego, Calif., Academic Press, p. 375-402.

Porter, S.D.; Cuffney, T.F.; Gurtz, M.E.; and Meador, M.R., 1993, Methods for the collecting algal samples as part of the National Water-Quality Assessment program: U.S. Geological Survey Open-File Report 93-409, 39 p.
Robinson, C.T.; Minshall, G.W.; and Royer, T.V., 2000, Inter-annual patterns in macroinvertebrate communities of wilderness streams in Idaho, U.S.A.: Hydrobiologia, v. 421, p. $187-198$.

Santa Ana Watershed Project Authority, 2003, About the watershed-population: accessed June 9, 2003, at http:// www.sawpa.org/about/watershed.htm\#Population.

Sherwood, A.R.; Rintoul, T.L.; Müller, K.M.; and Sheath, T.G., 2000, Seasonality and distribution of epilithic diatoms, macroalgae, and macrophytes in a spring-fed stream system in Ontario, Canada: Hydrobiologia, v. 435, p. 143-152.

Slavik, Ondrej, and Bartos, Ludek; 2001, Spatial distribution and temporal variance of fish communities in the channelized and regulated Vltava River (Central Europe): Environmental Biology of Fishes, v. 61, no. 1, p. 47-55.

U.S. Army Corps of Engineers, 1994, Water control manual, Prado Dam and Reservoir, Santa Ana River, Californi, 83 p.

U.S. Environmental Protection Agency, Level III ecoregions, accessed Sept. 3, 2004, at http://www.epa.gov/wed/pages/ ecoregions/level_iii.htm.

Van Dam, H.; Mertens, A.; and Sinkeldam, J., 1994, A coded checklist and ecological indicator values of freshwater diatoms from the Netherlands: Netherlands Journal of Aquatic Ecology, v. 28, no. 1, p. 117-133.

Vannote, R.L.; Minshall, G.W.; Cummins, K.W.; Sedell, J.R.; and Cushing, C.E., 1980, The river continuum concept: Canadian Journal of Fisheries and Aquatic Sciences, v. 37, p. 130-137.

Wahl, Martin, 2001, Small scale variability of benthic assemblages—biogenic neighborhood effects: Journal of Experimental Marine Biology and Ecology, v. 258, no. 1, p. 101-114.

Wiens, J.A., 1989, Spatial scaling in ecology: Functional Ecology, v. 3, p. 385-397. 


\section{Appendixes}




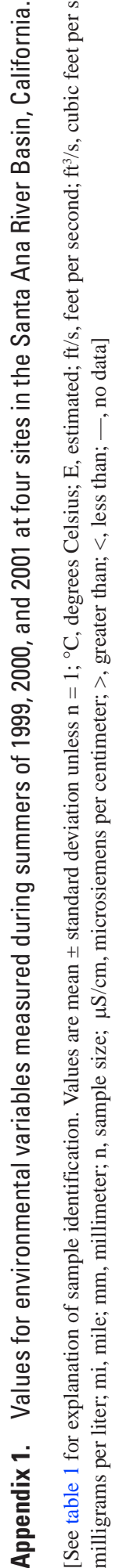

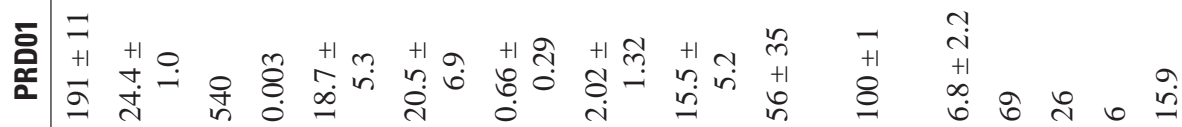

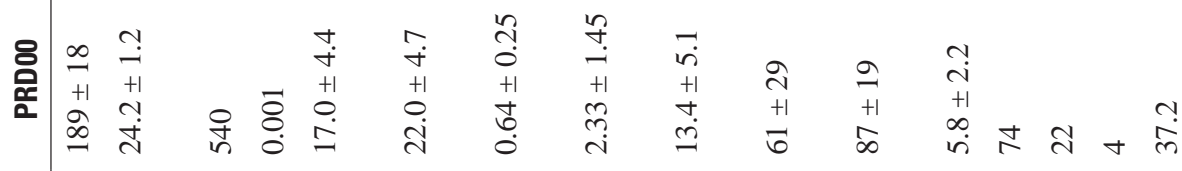

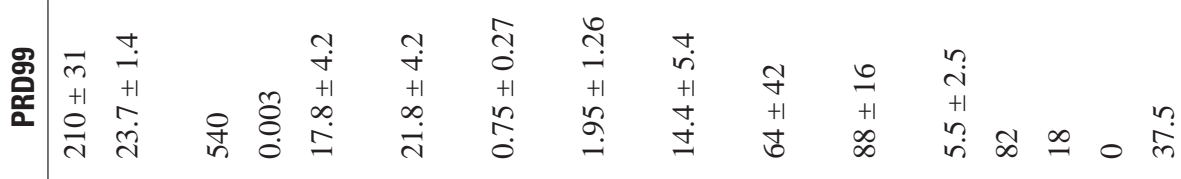

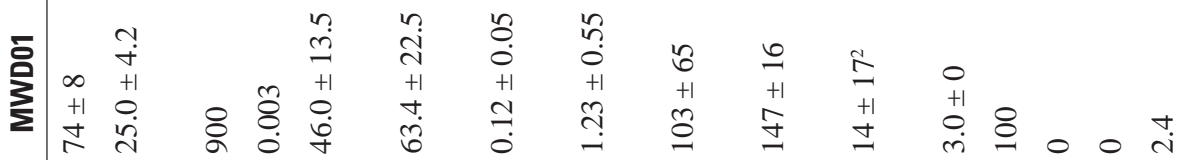

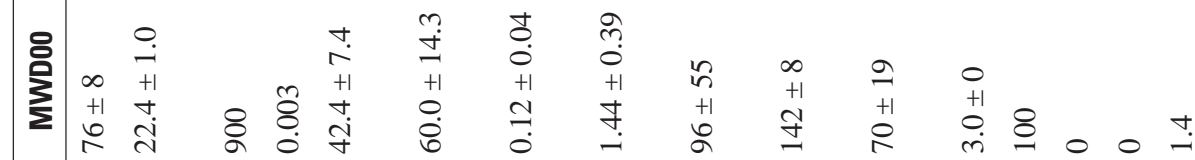



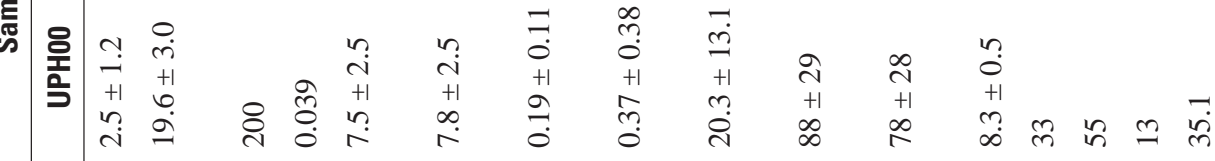

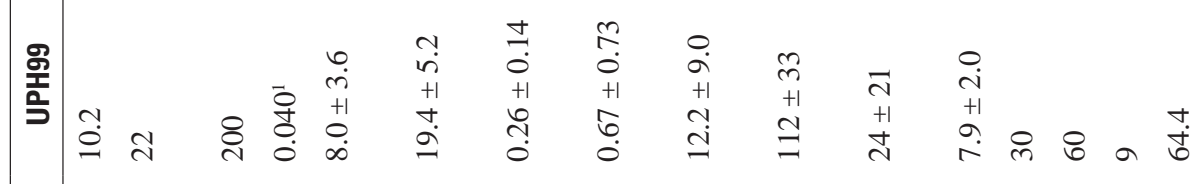

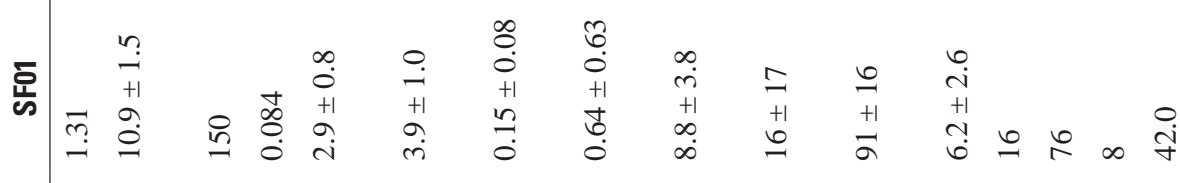

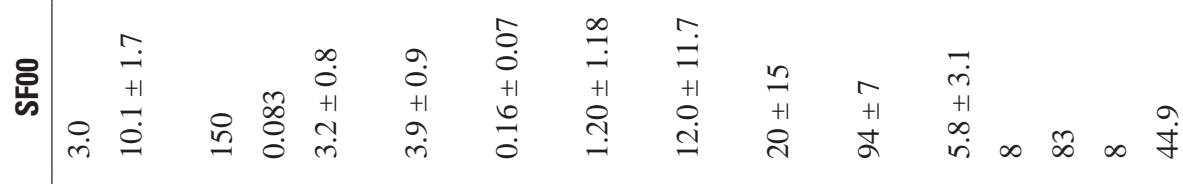

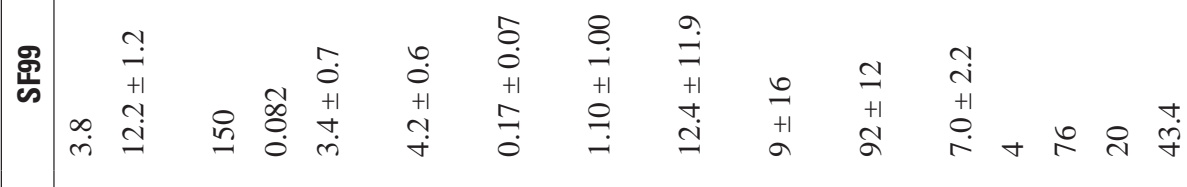

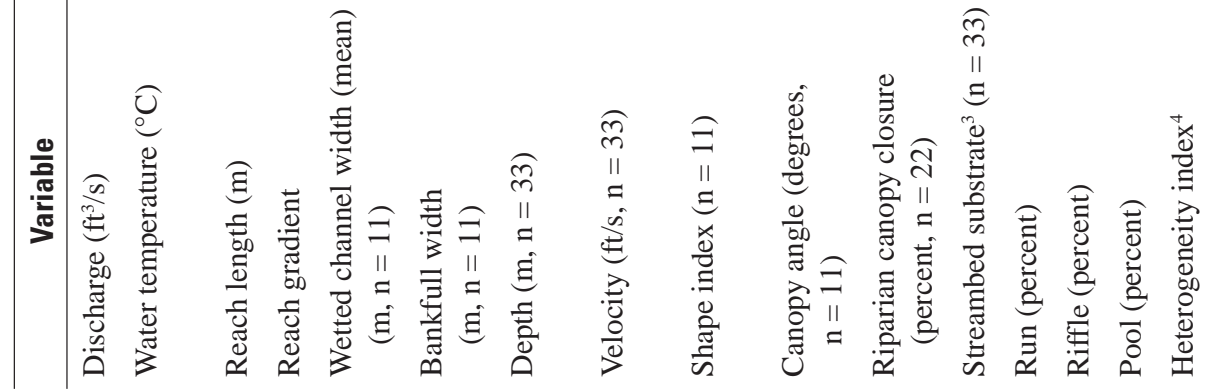




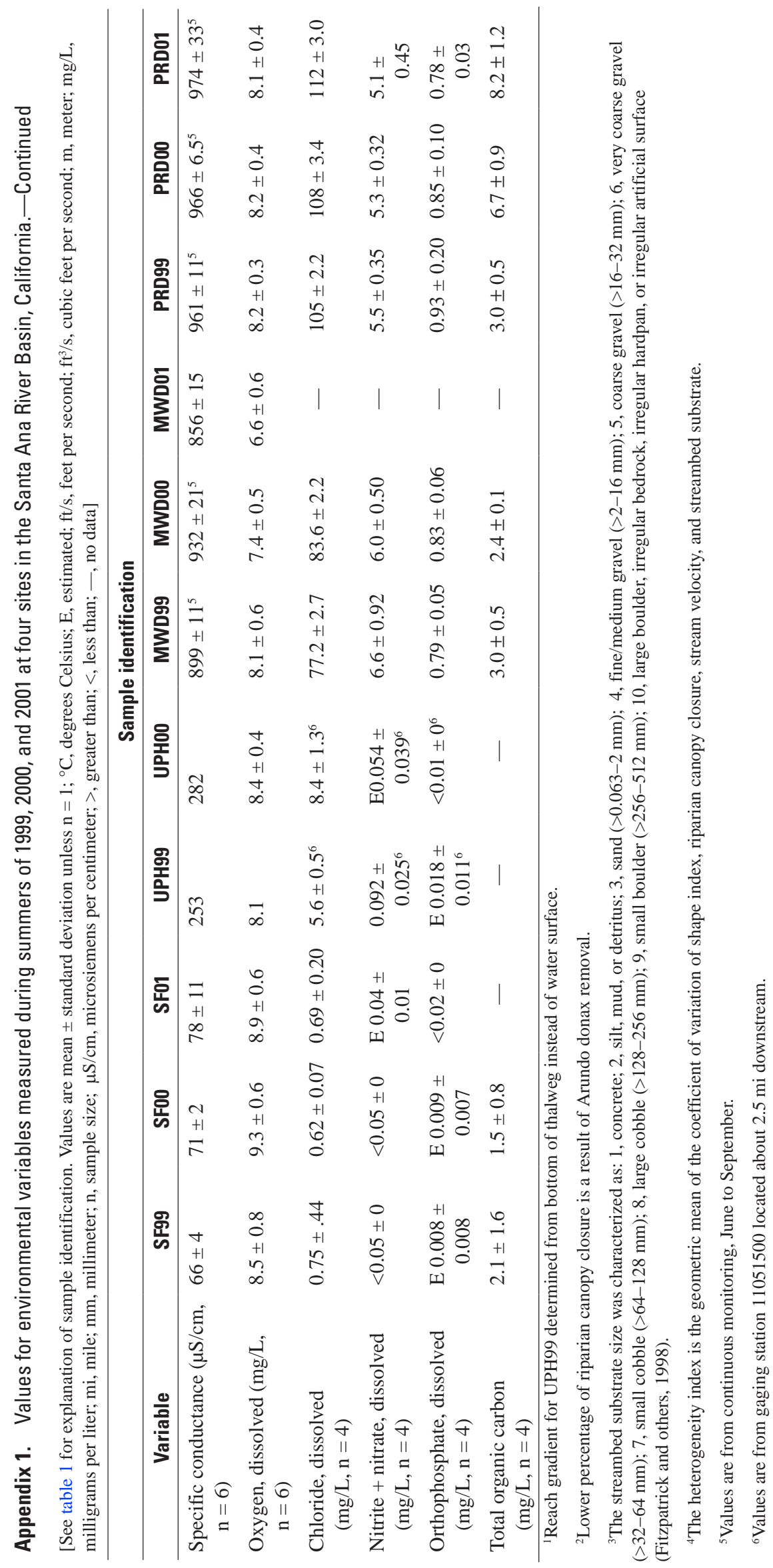




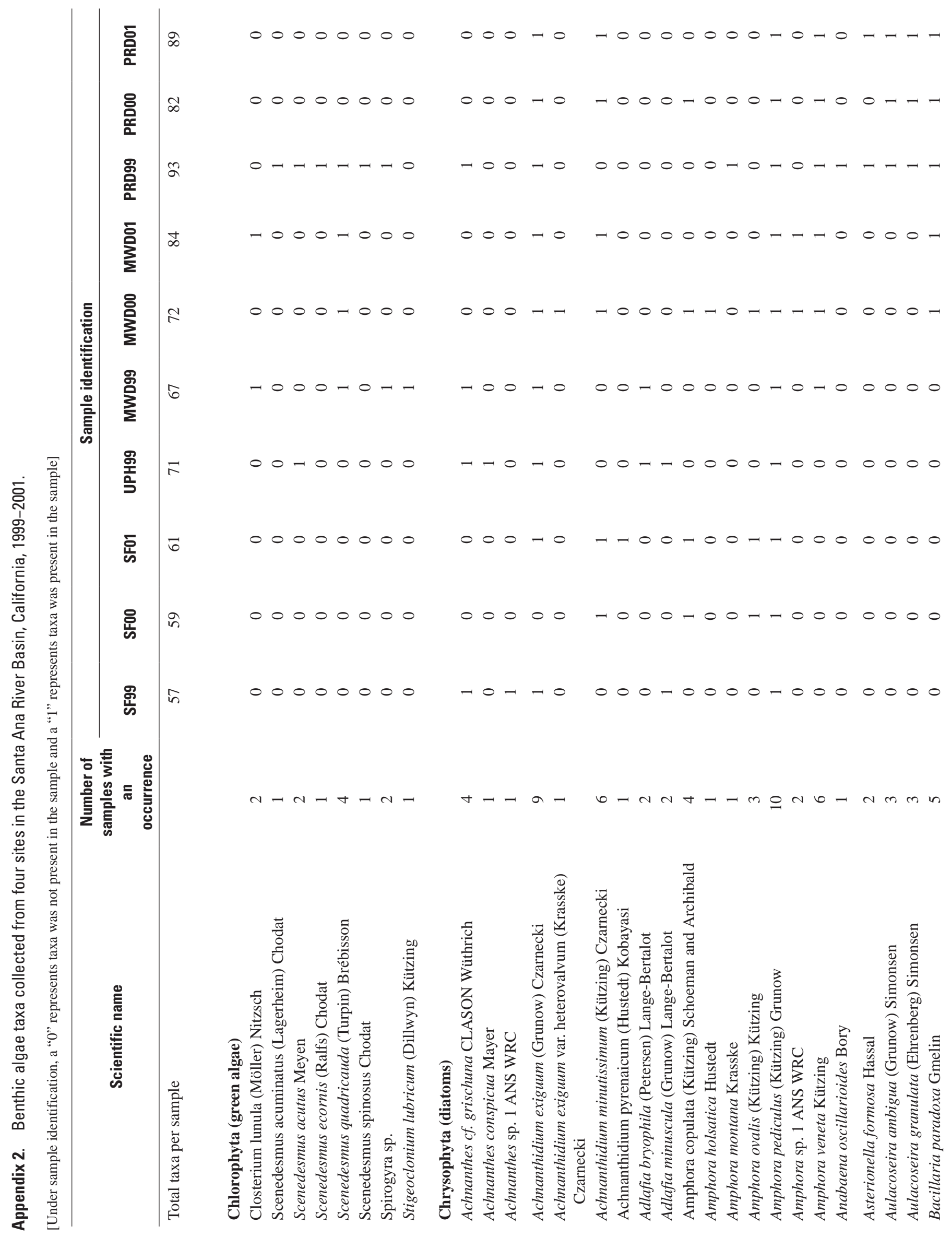




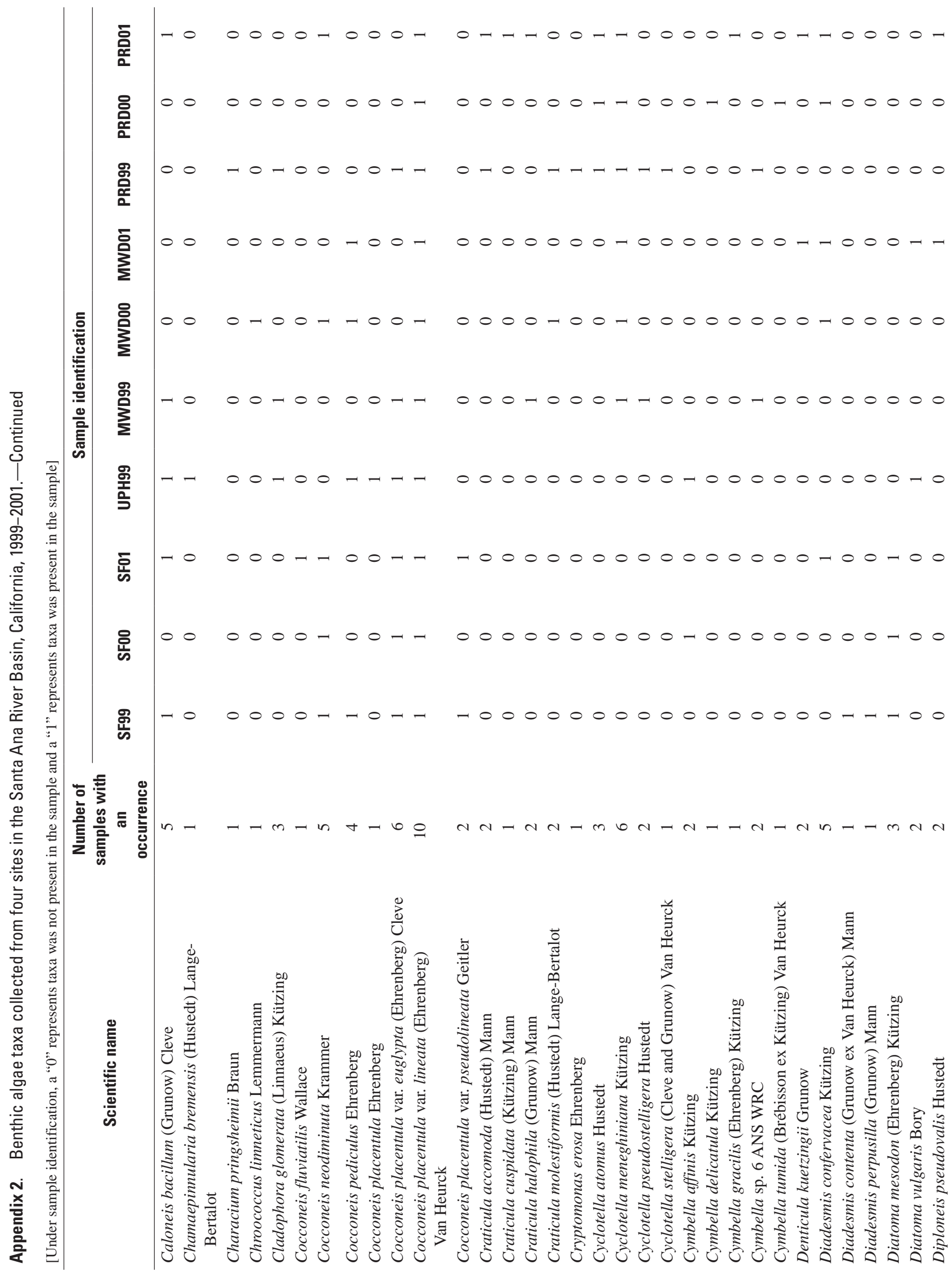




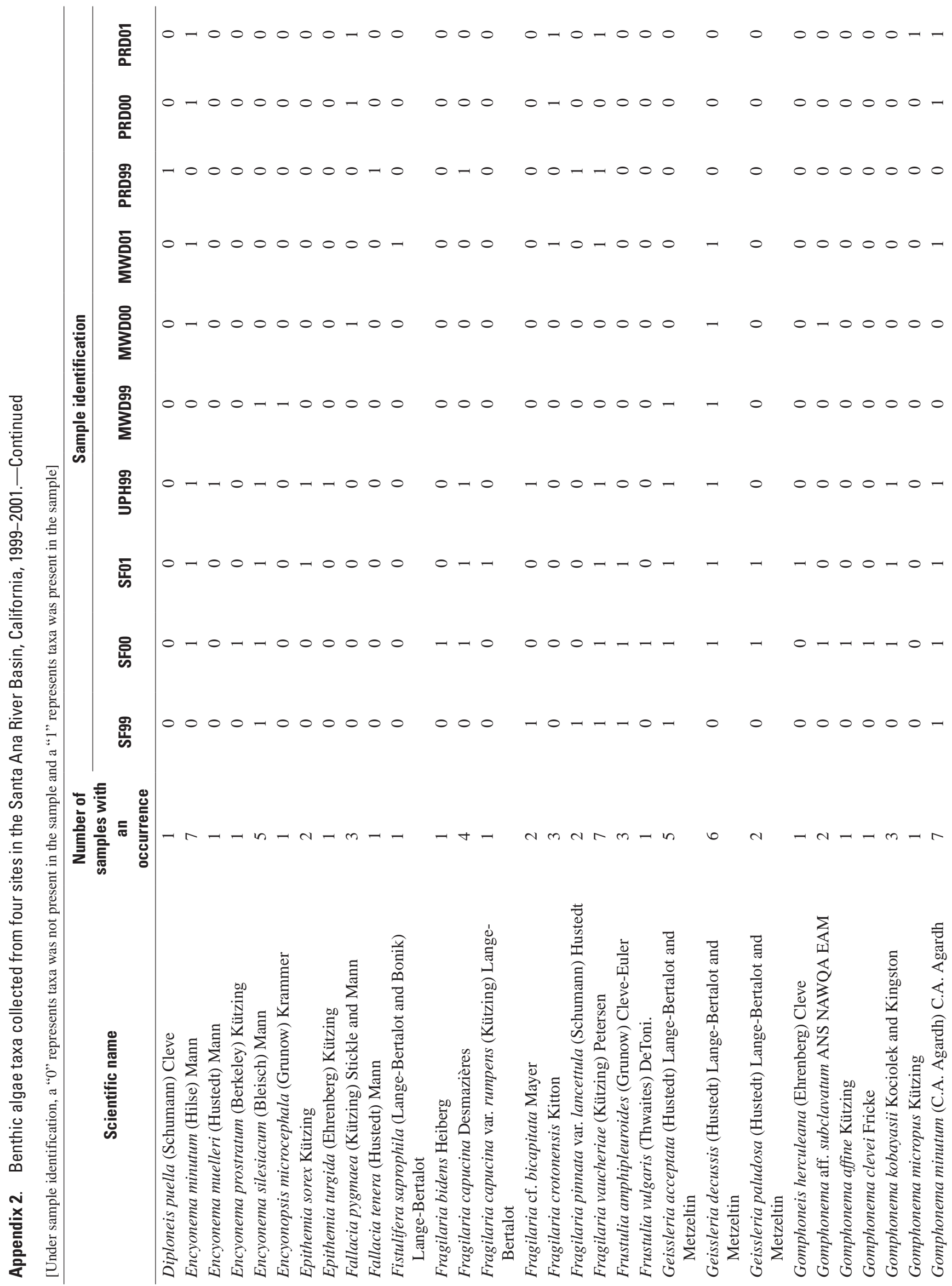




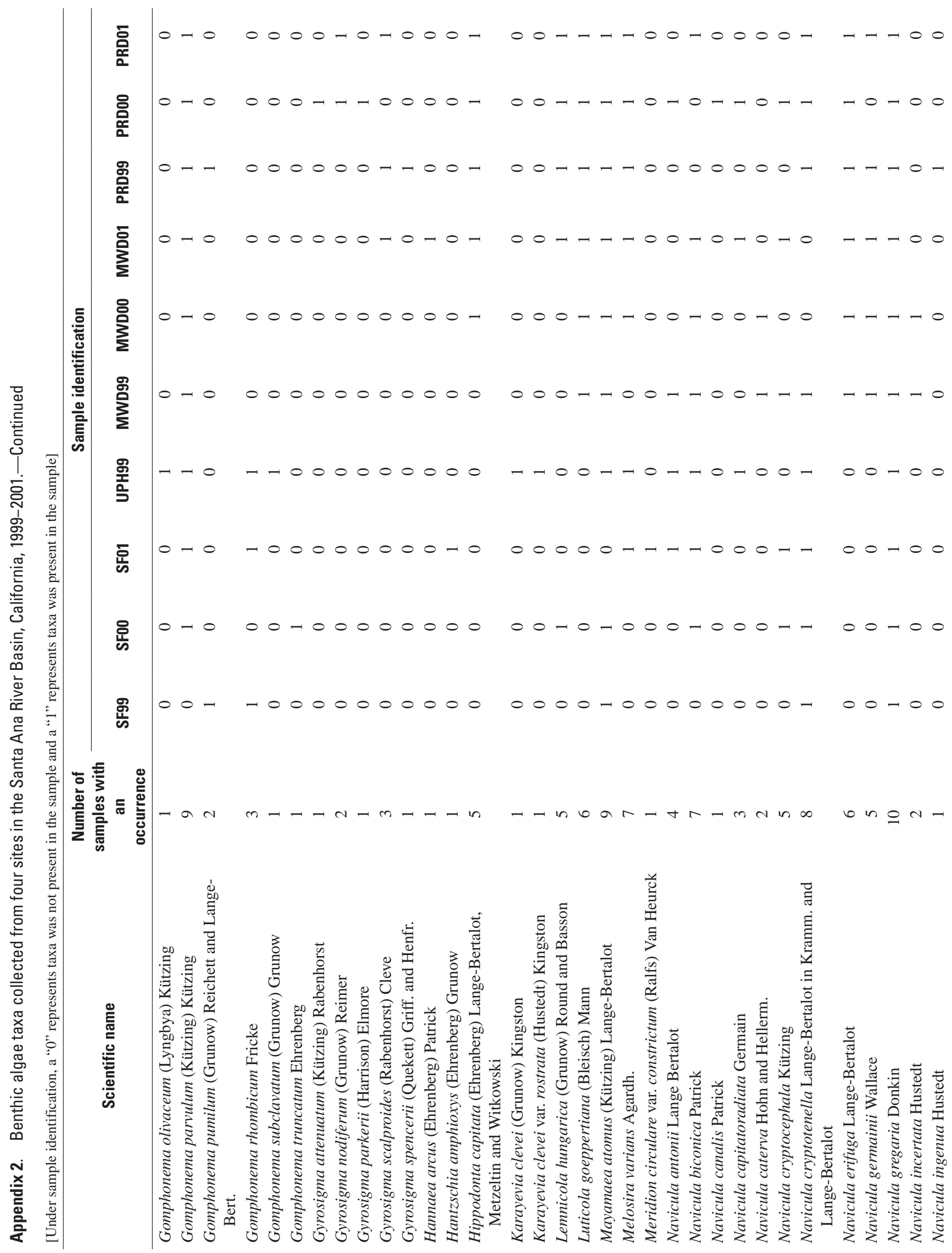




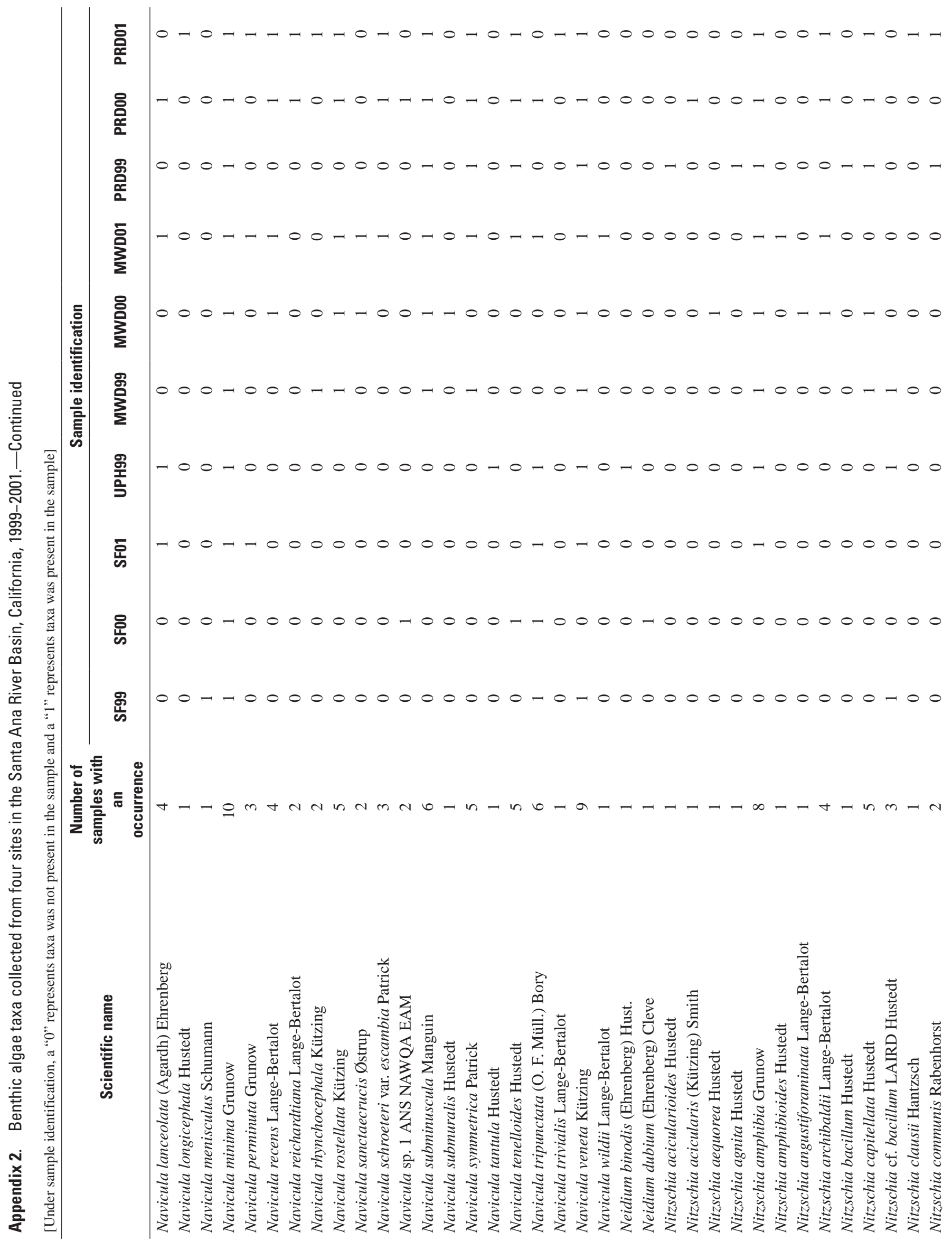




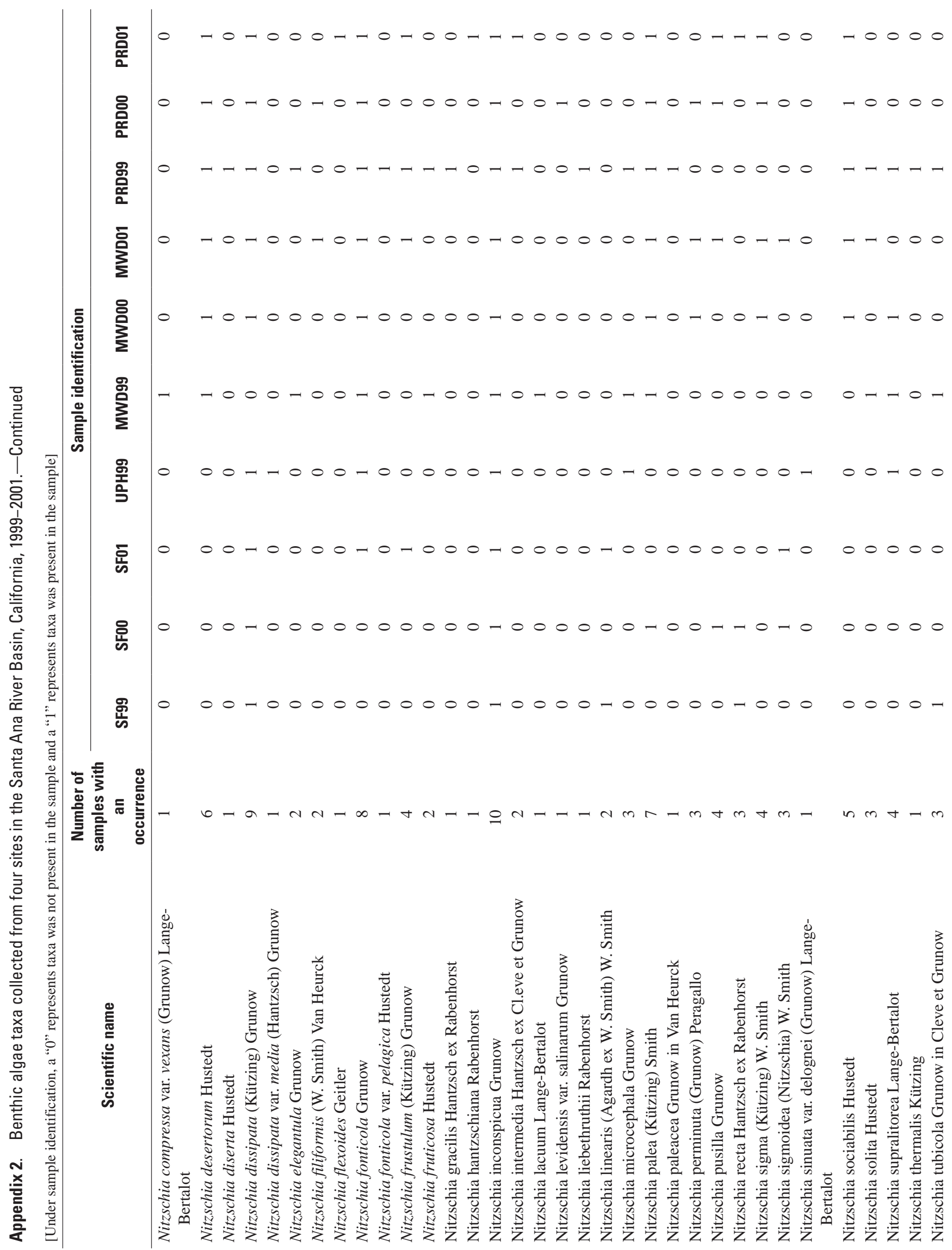




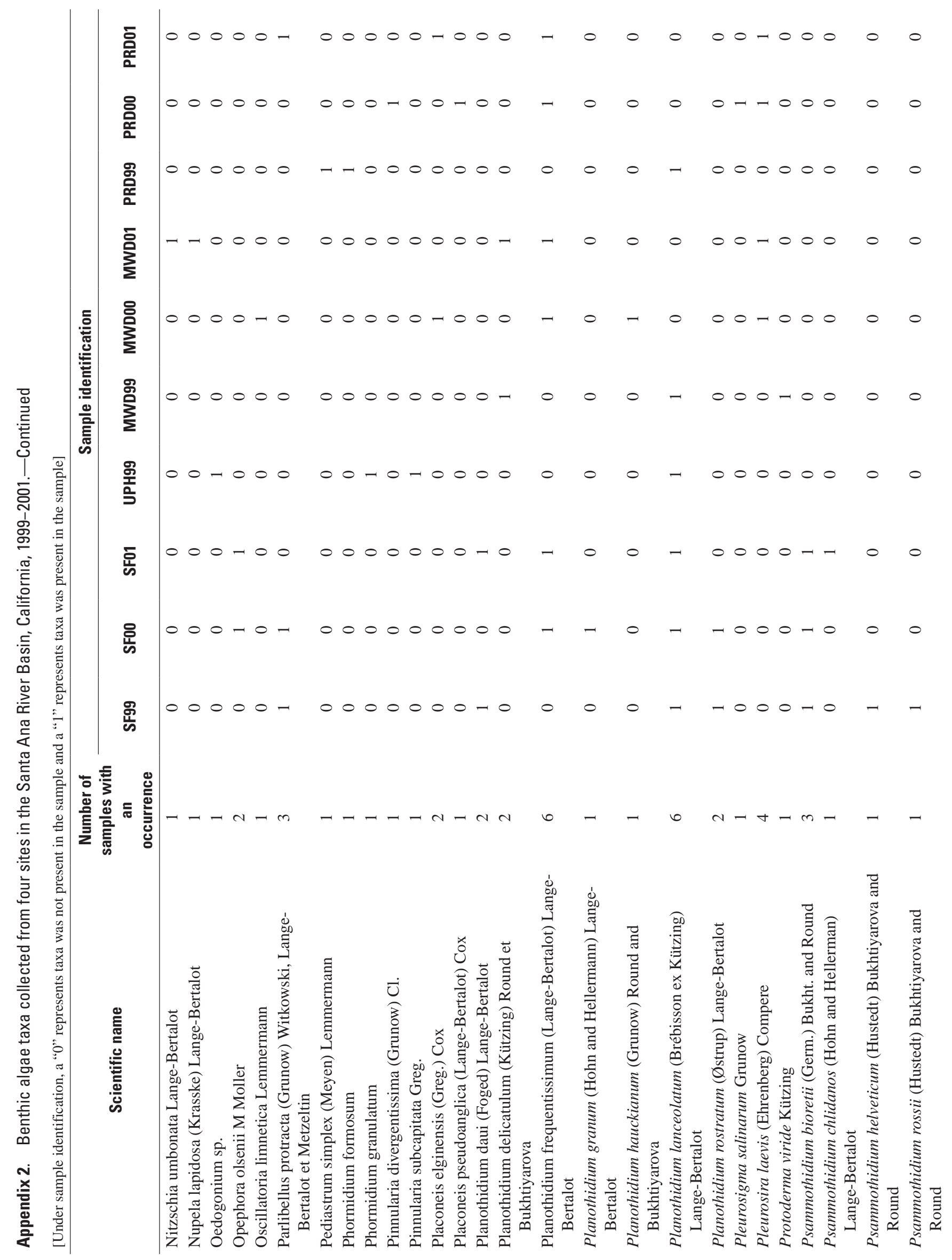




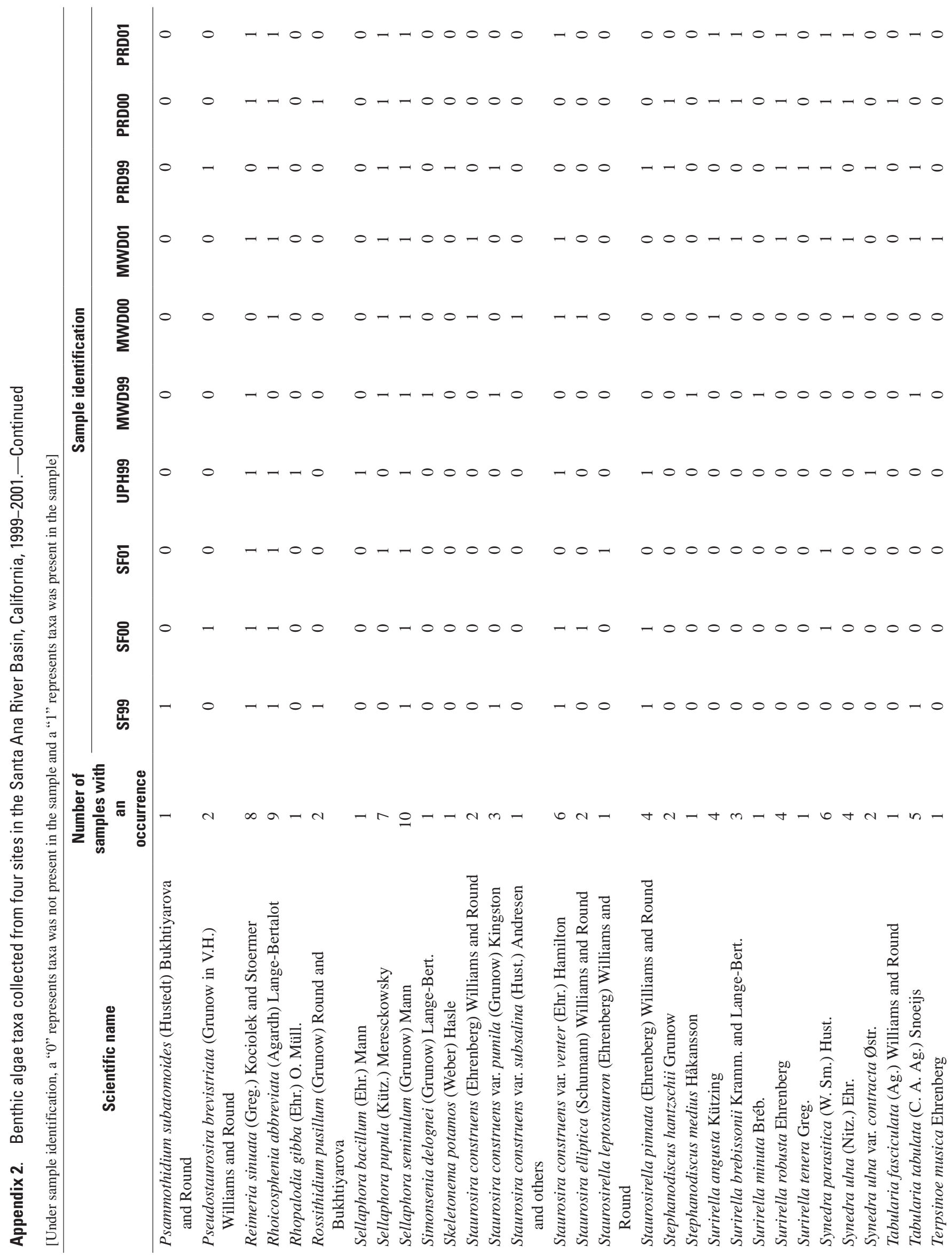




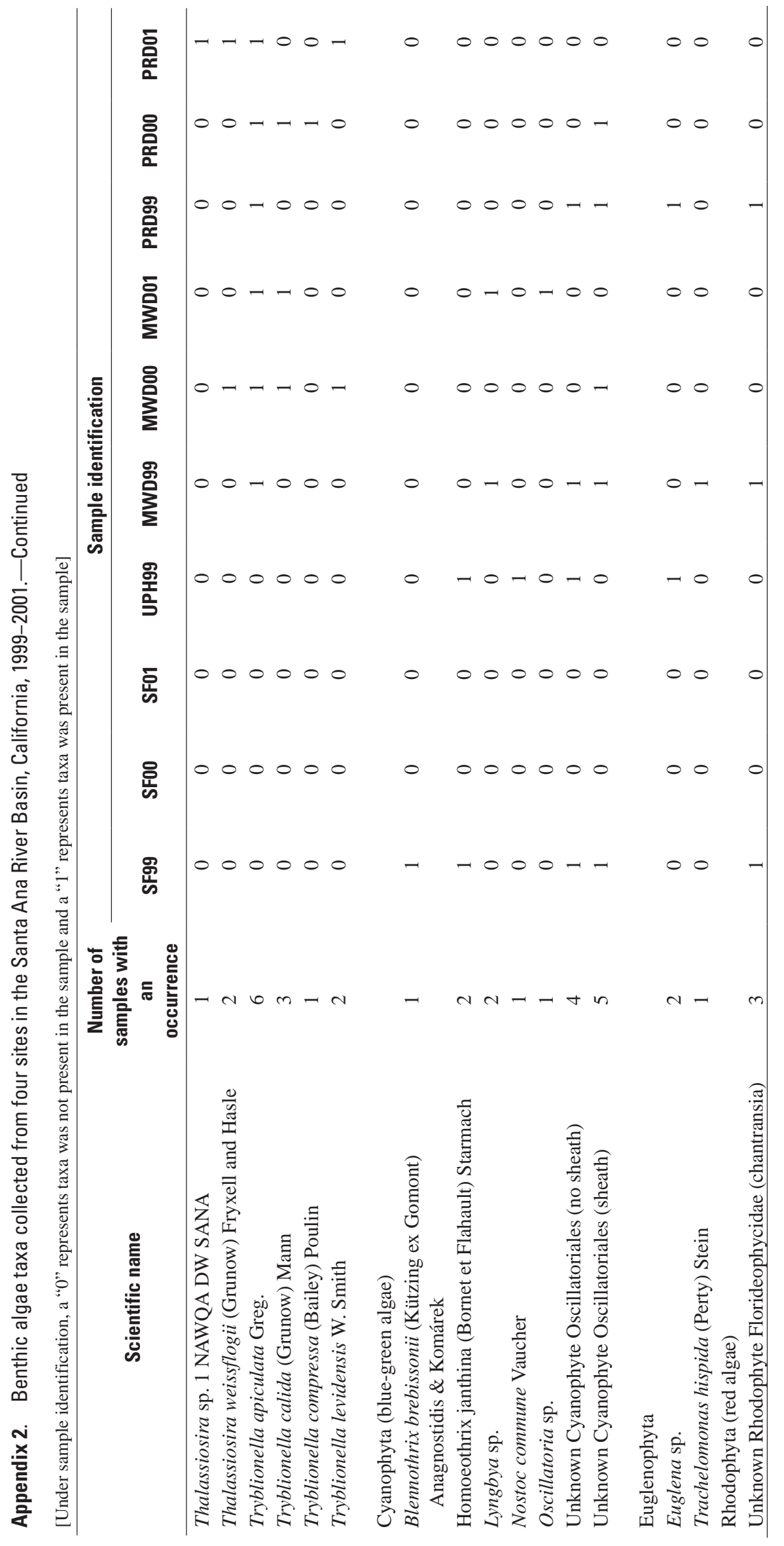




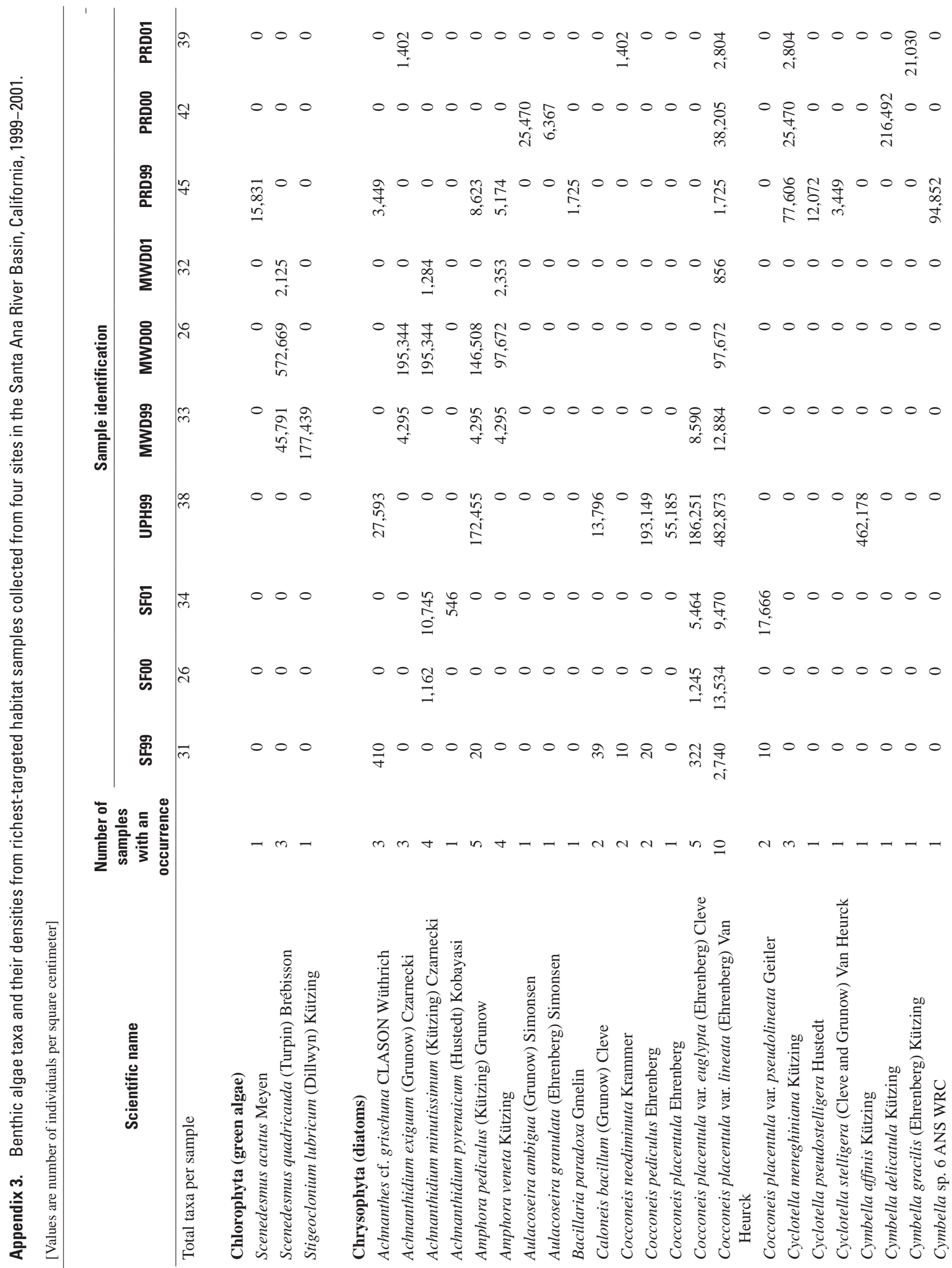


爰|

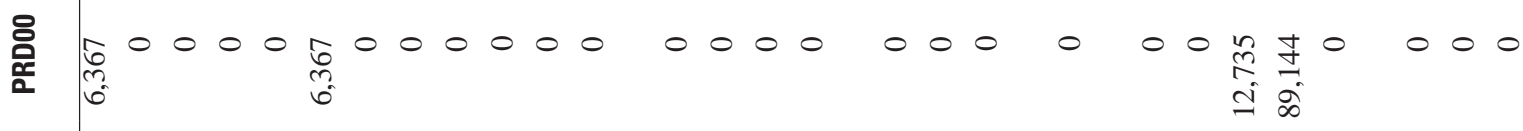

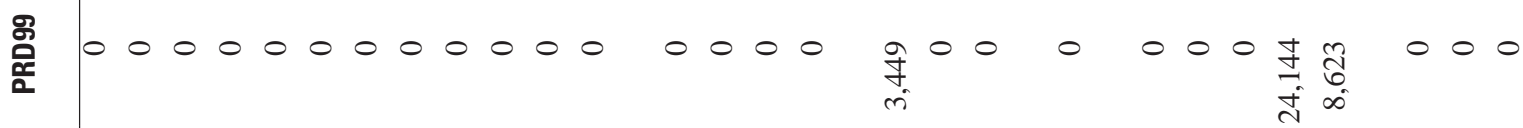

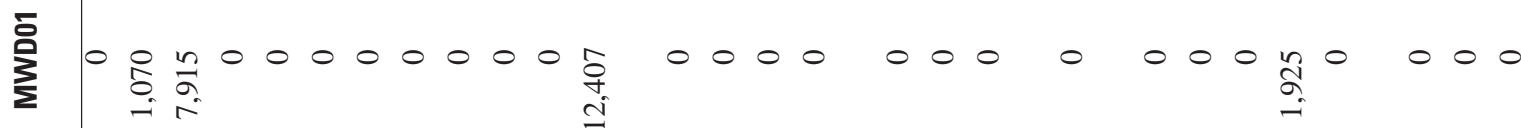

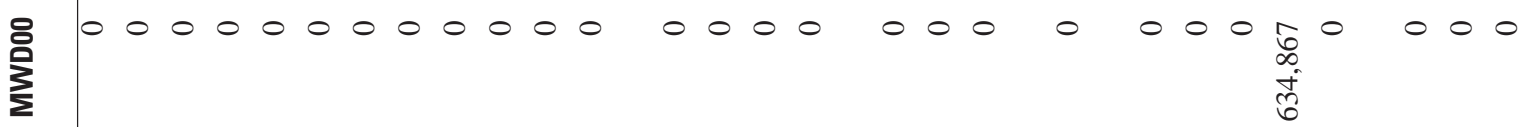

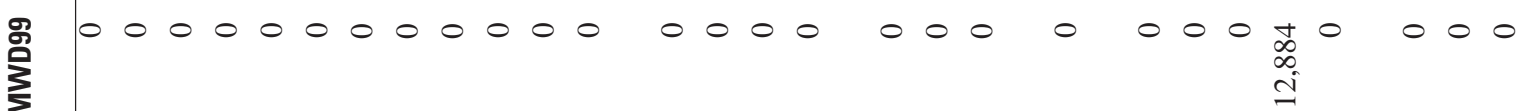

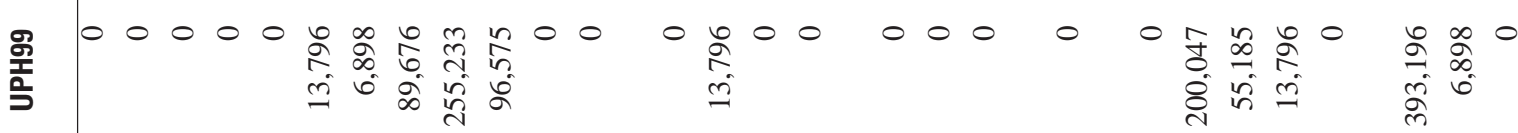

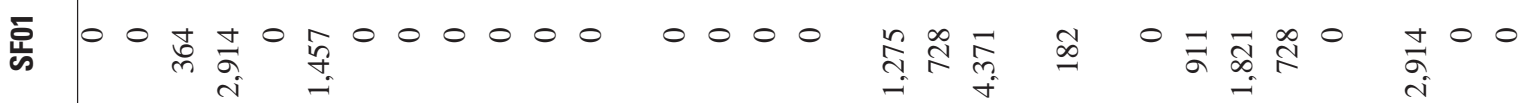

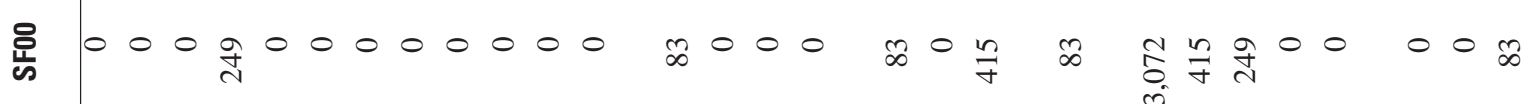

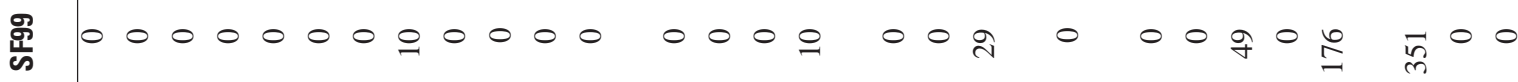

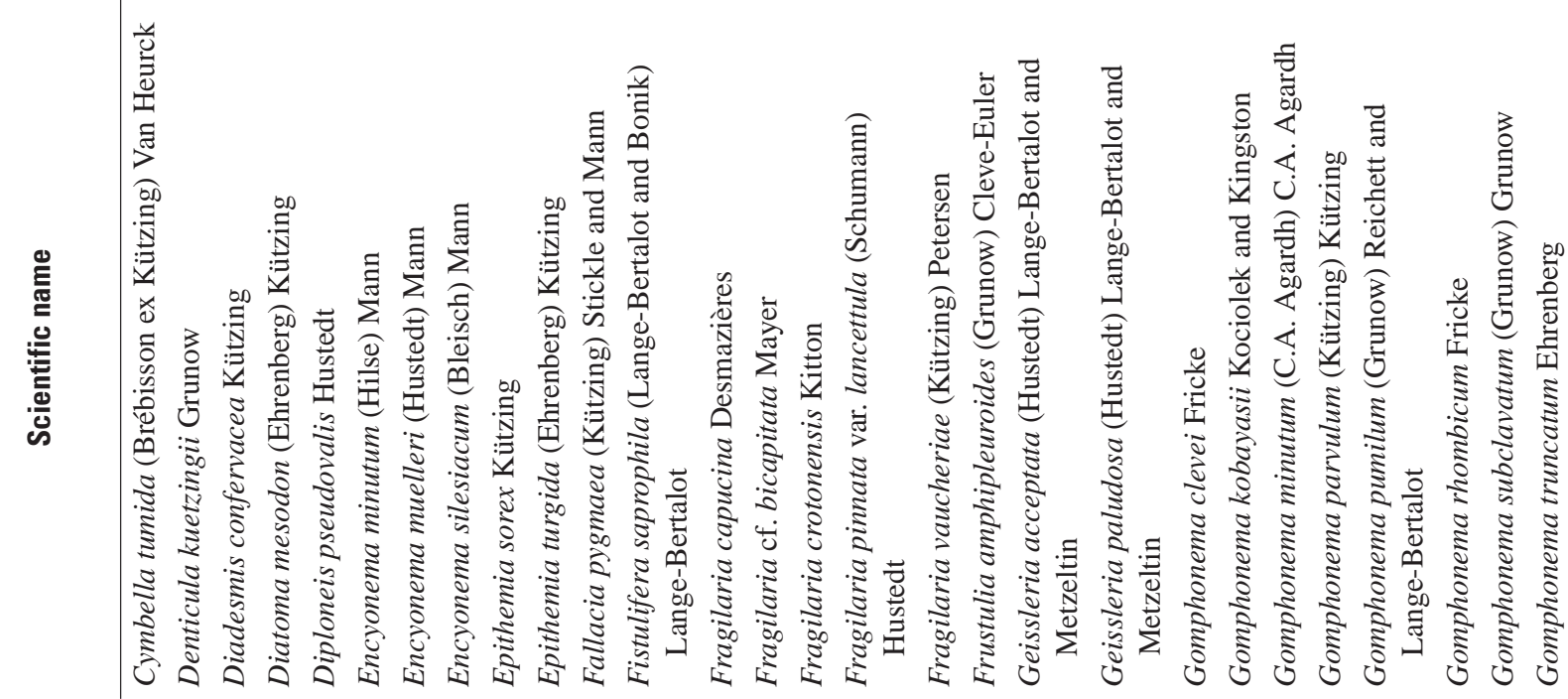




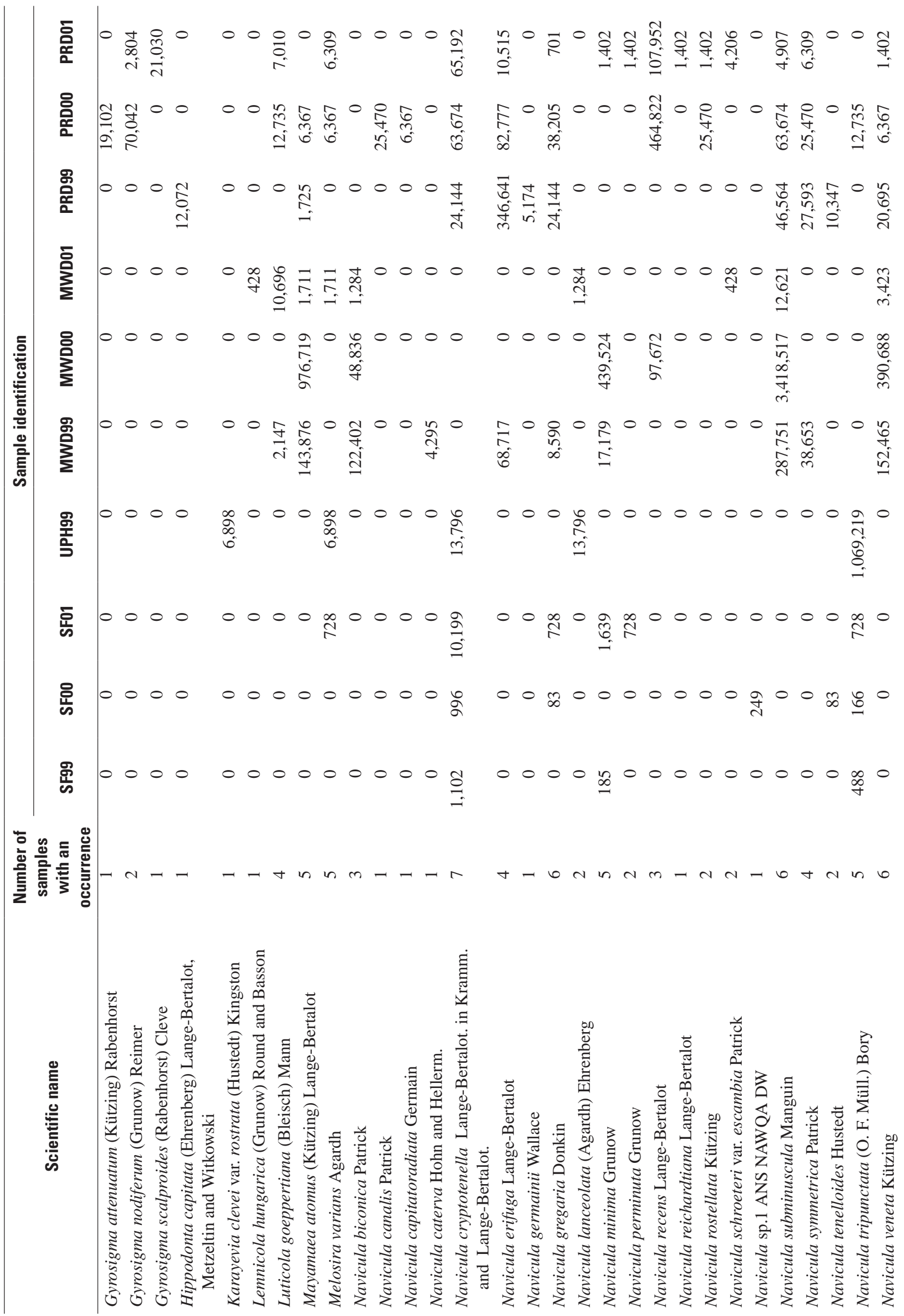




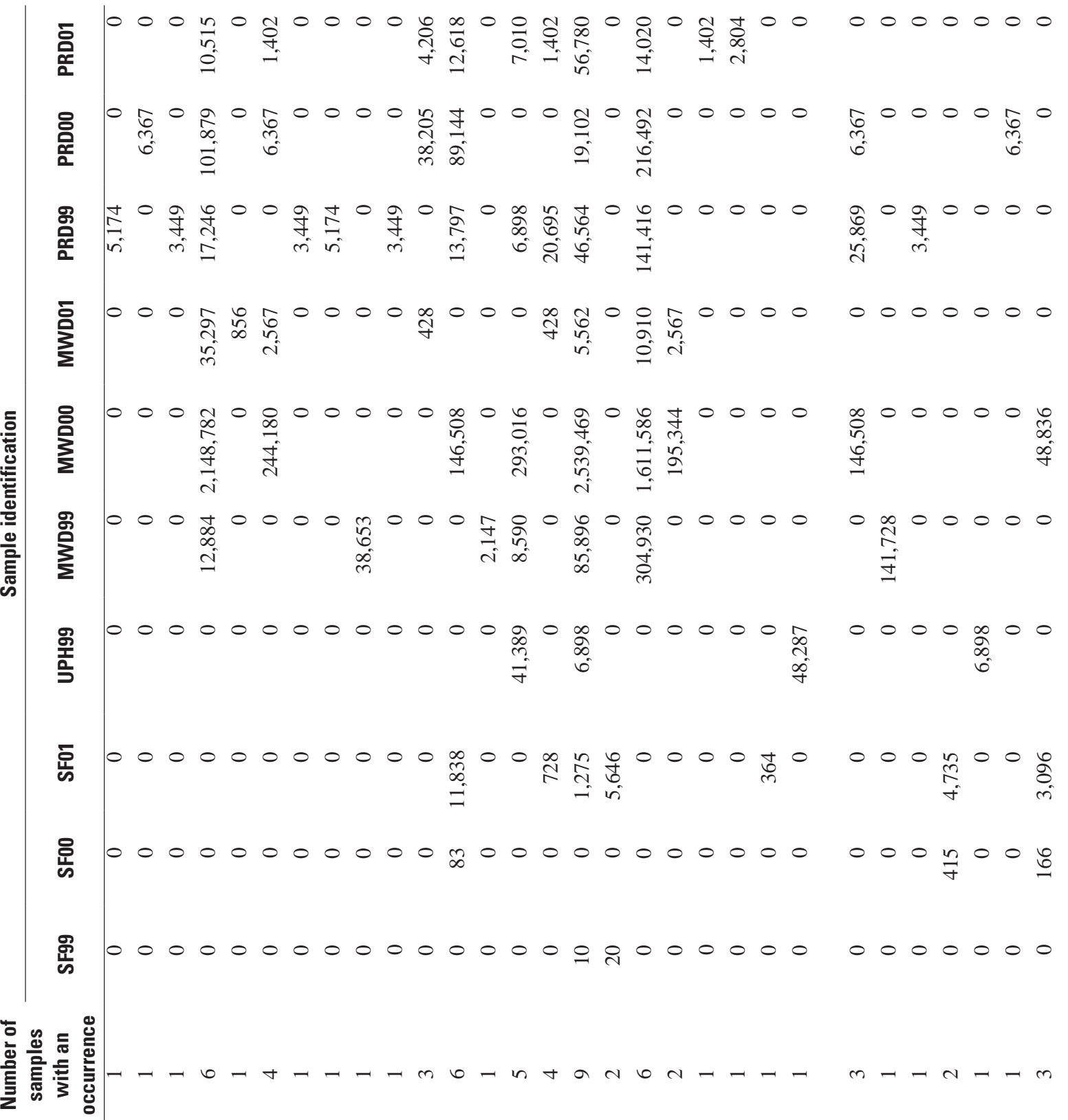

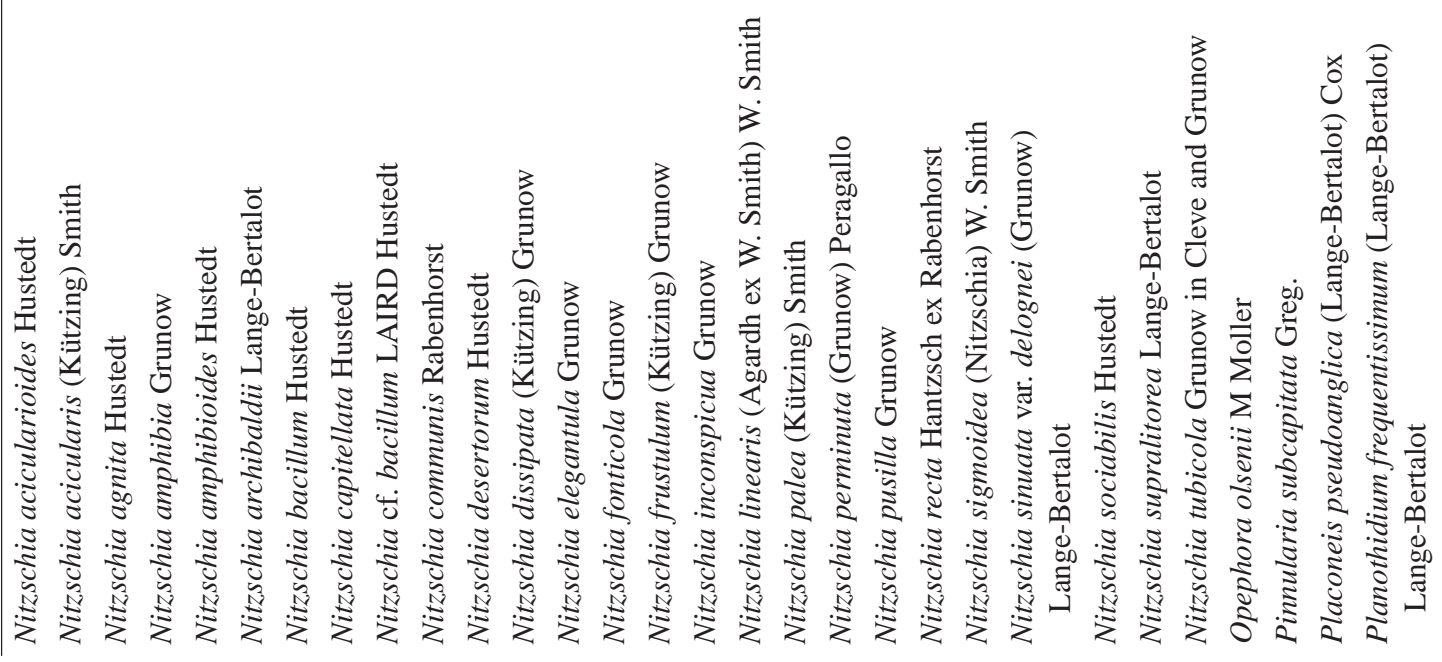




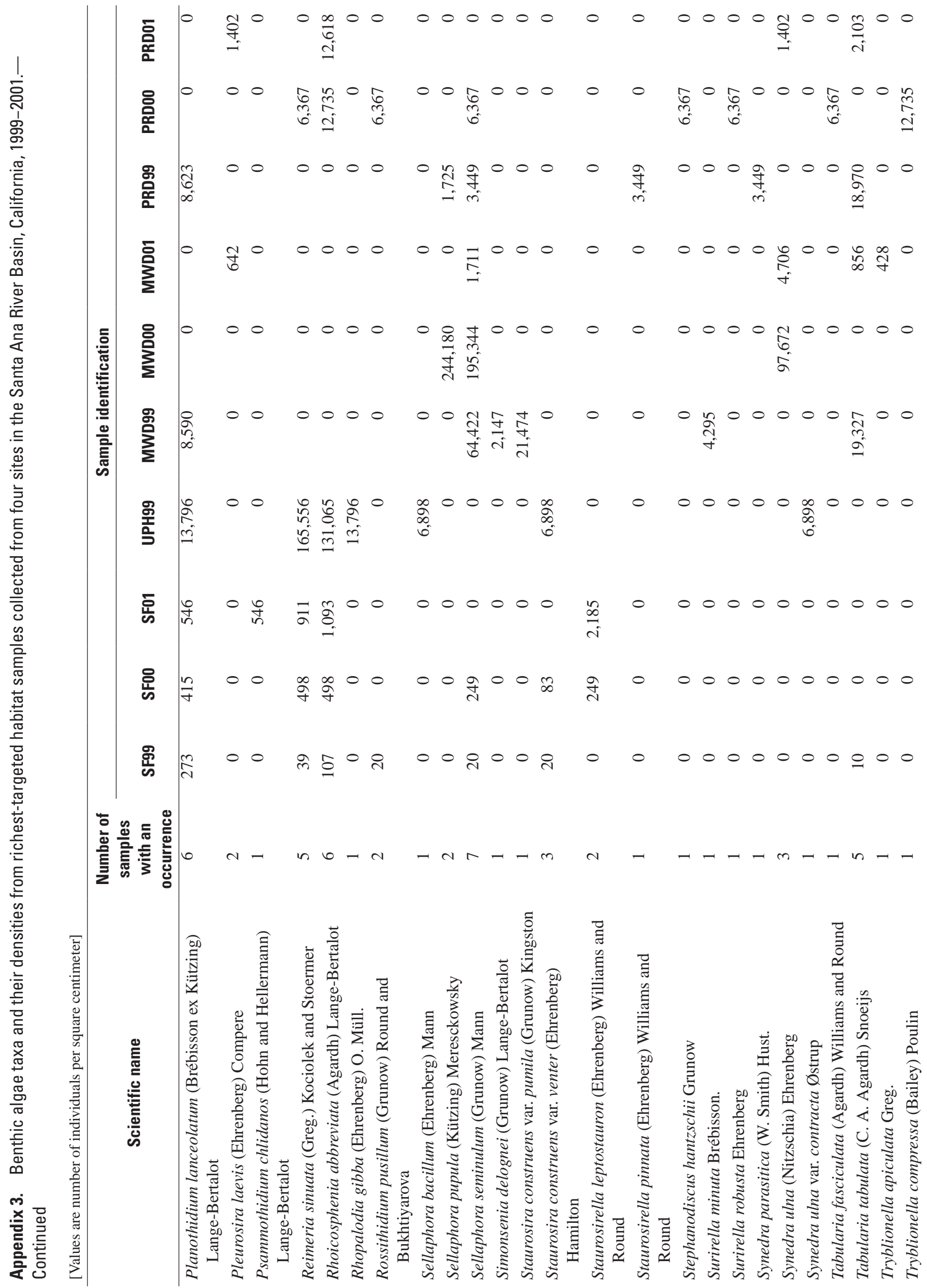




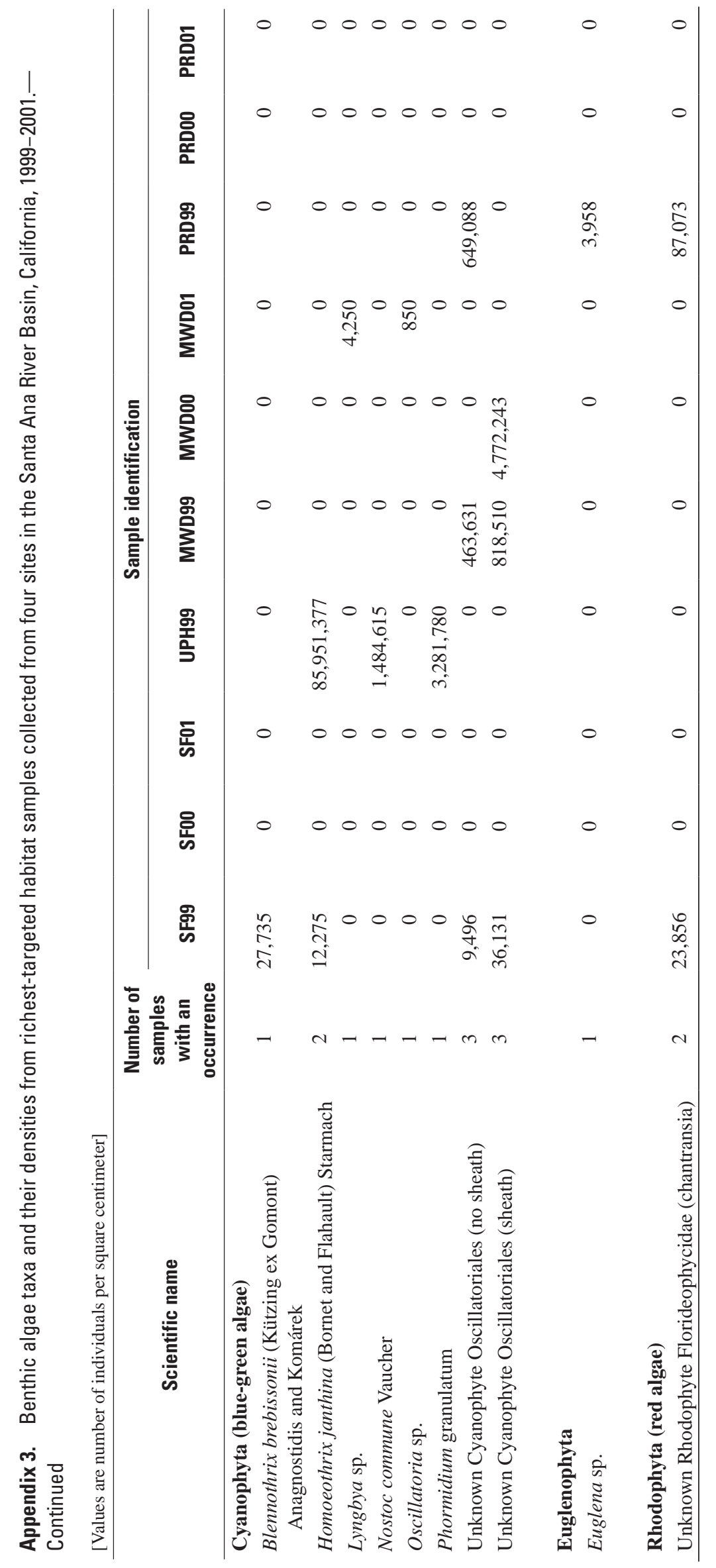




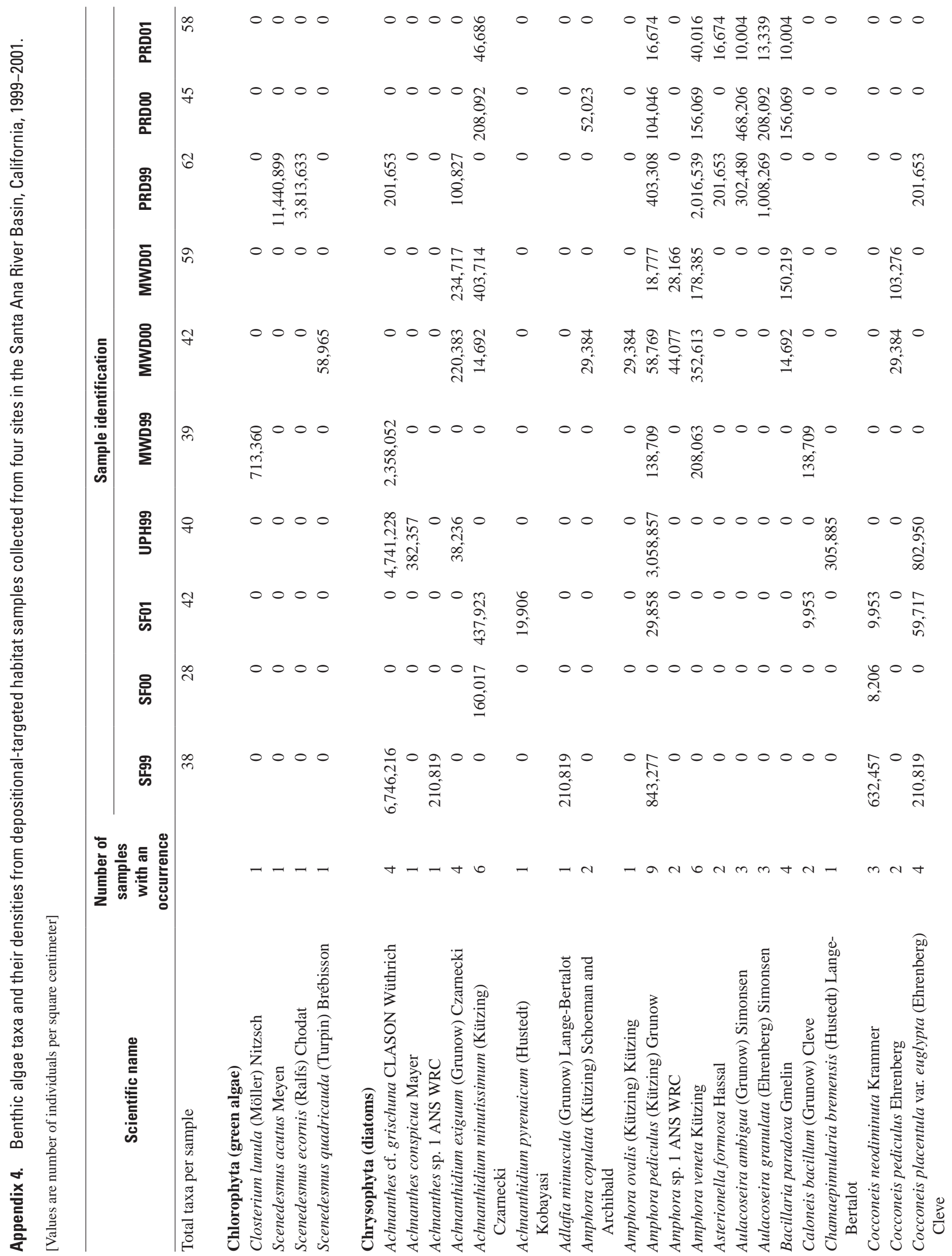




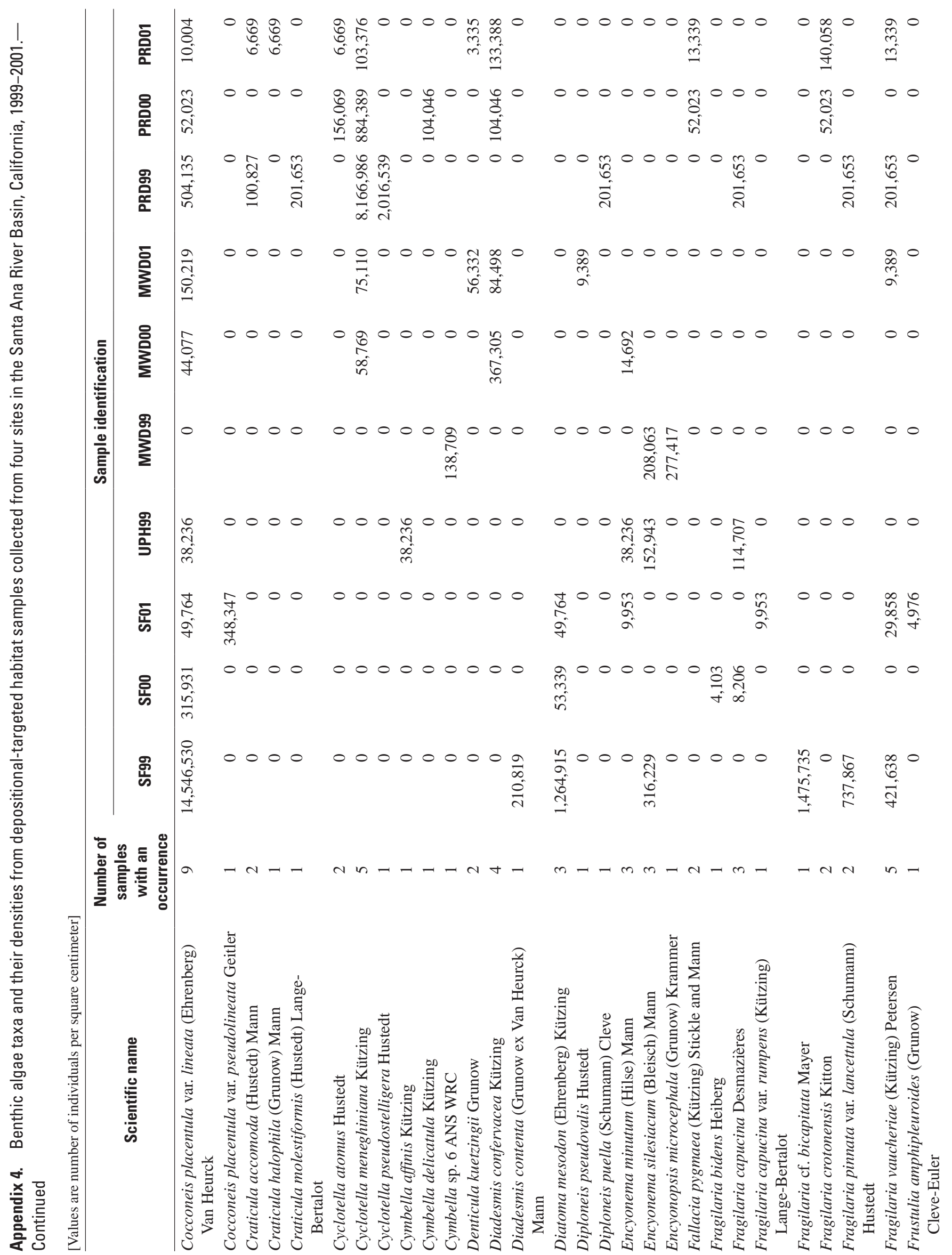




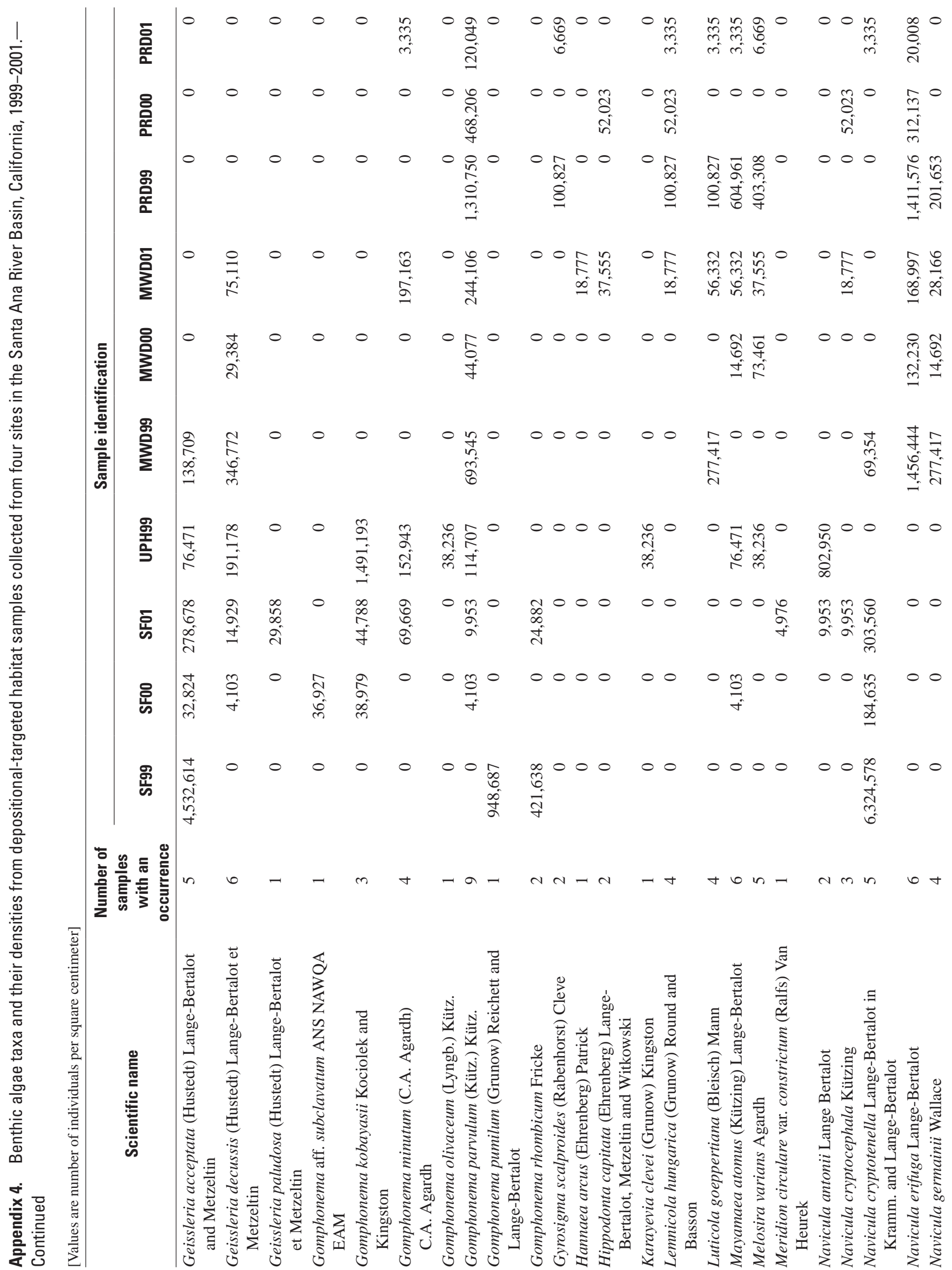




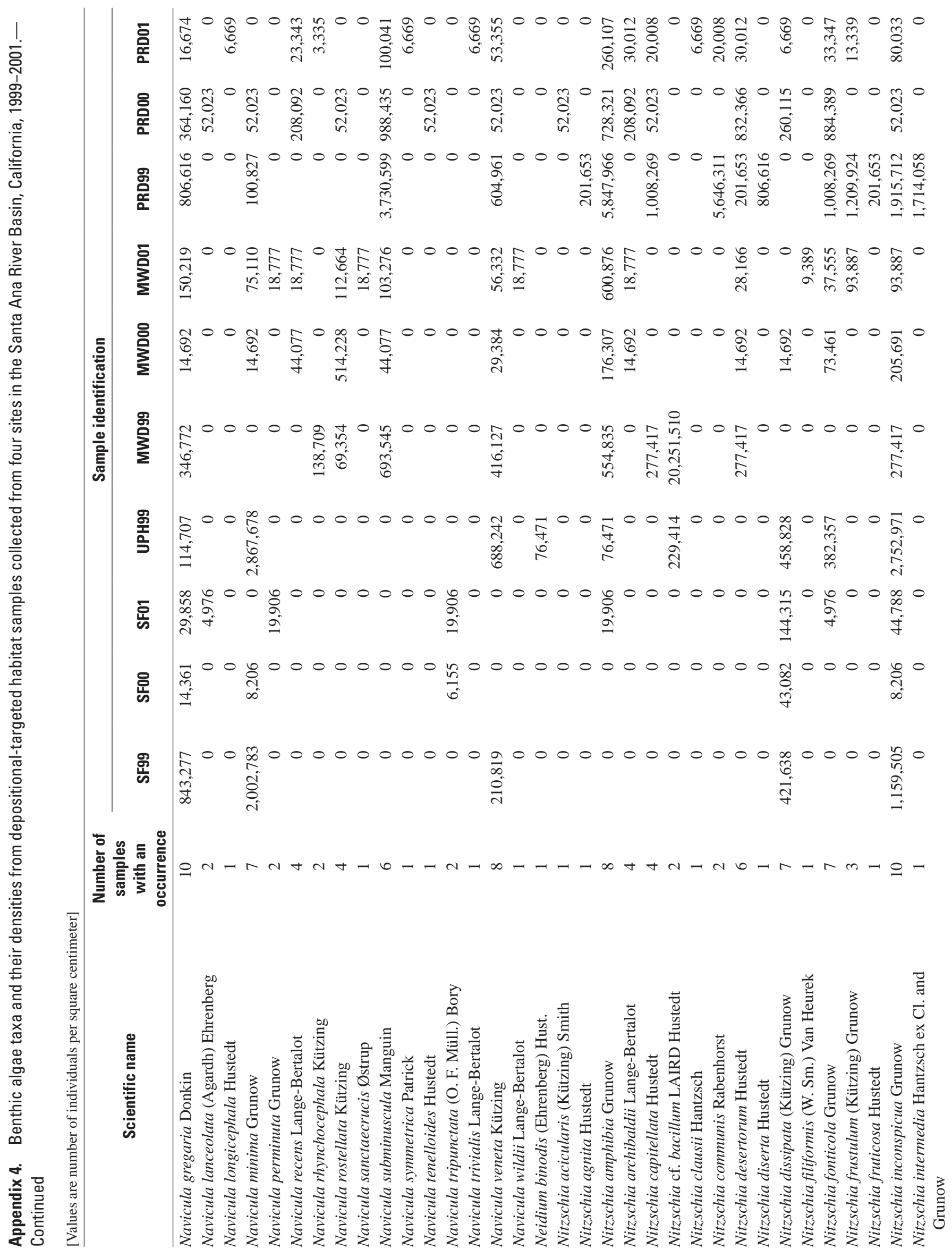




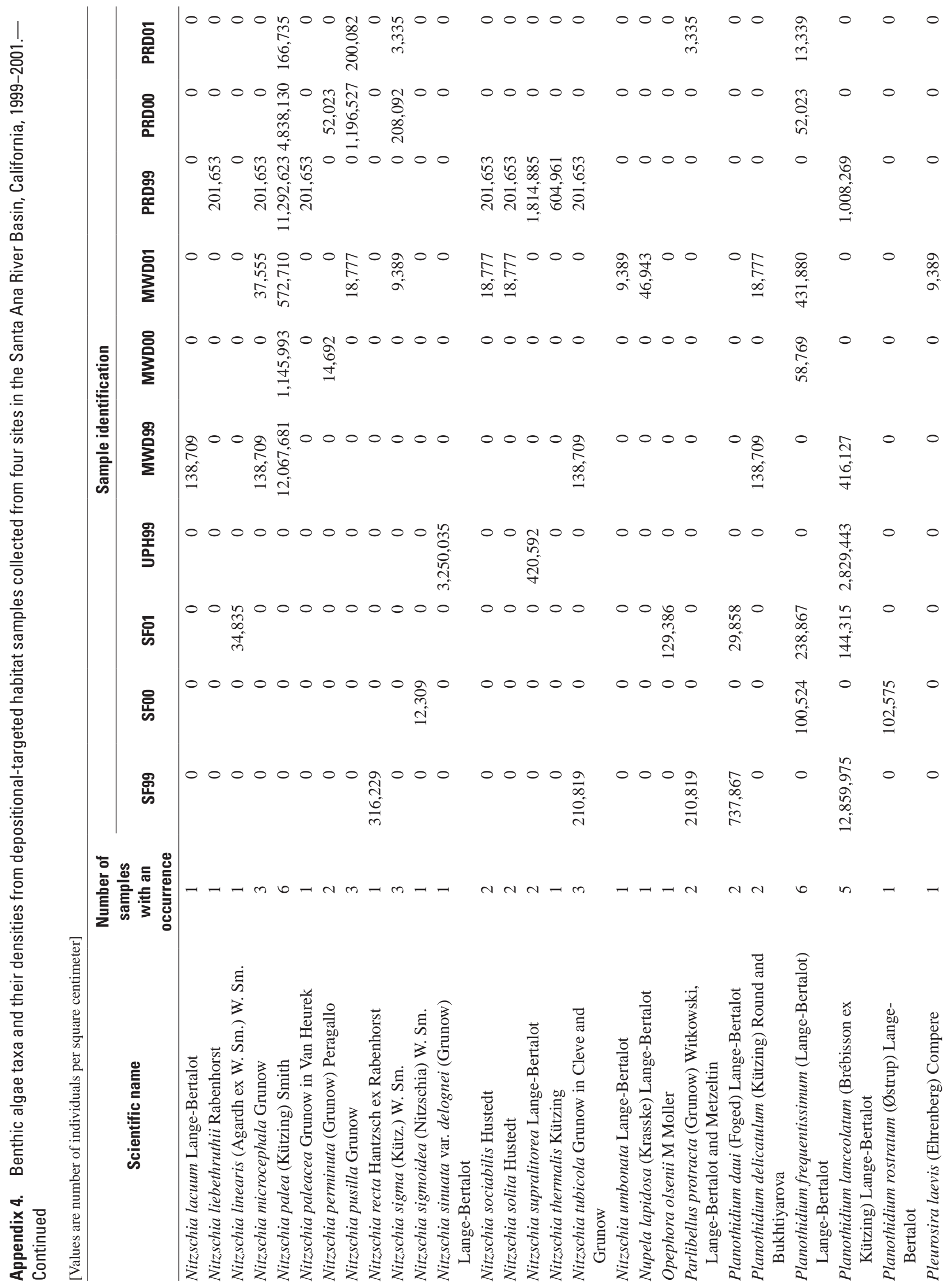




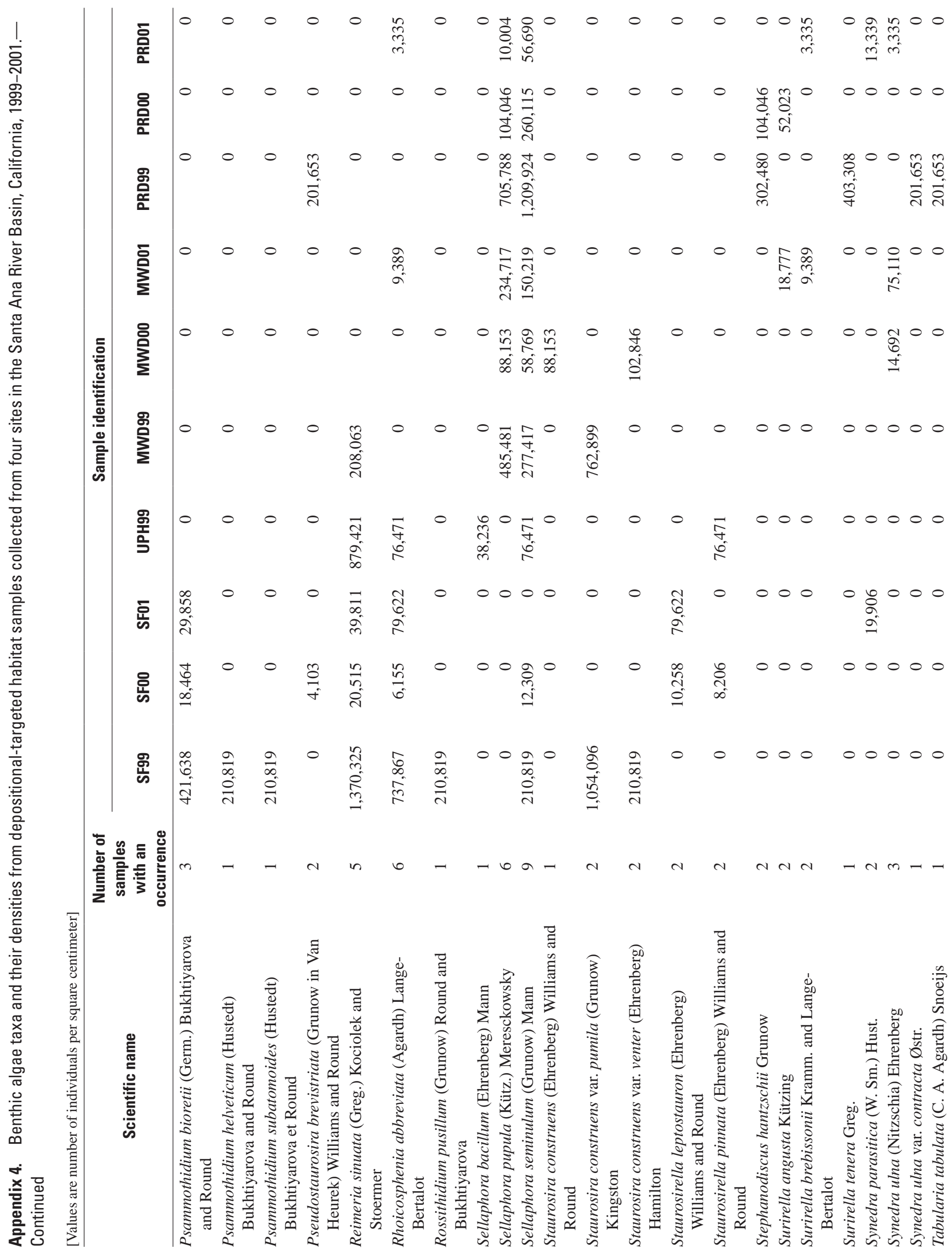




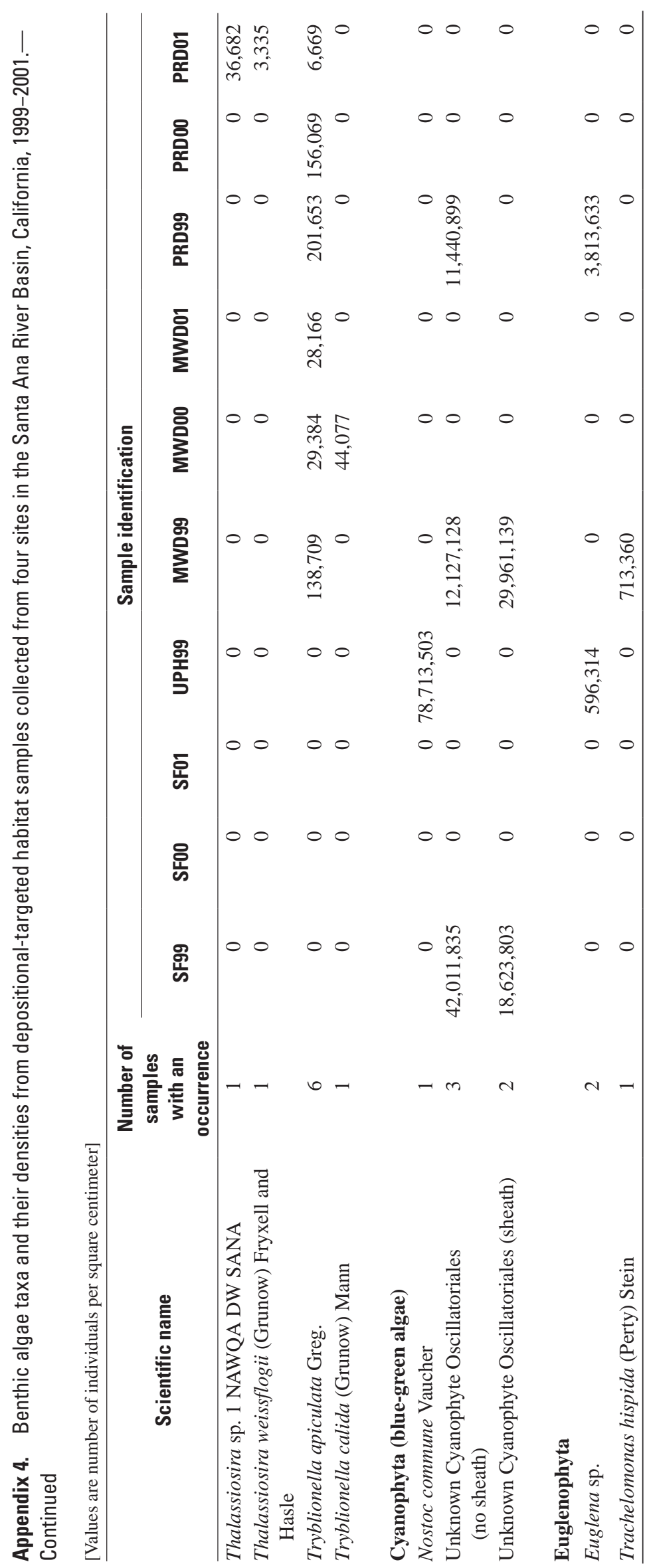




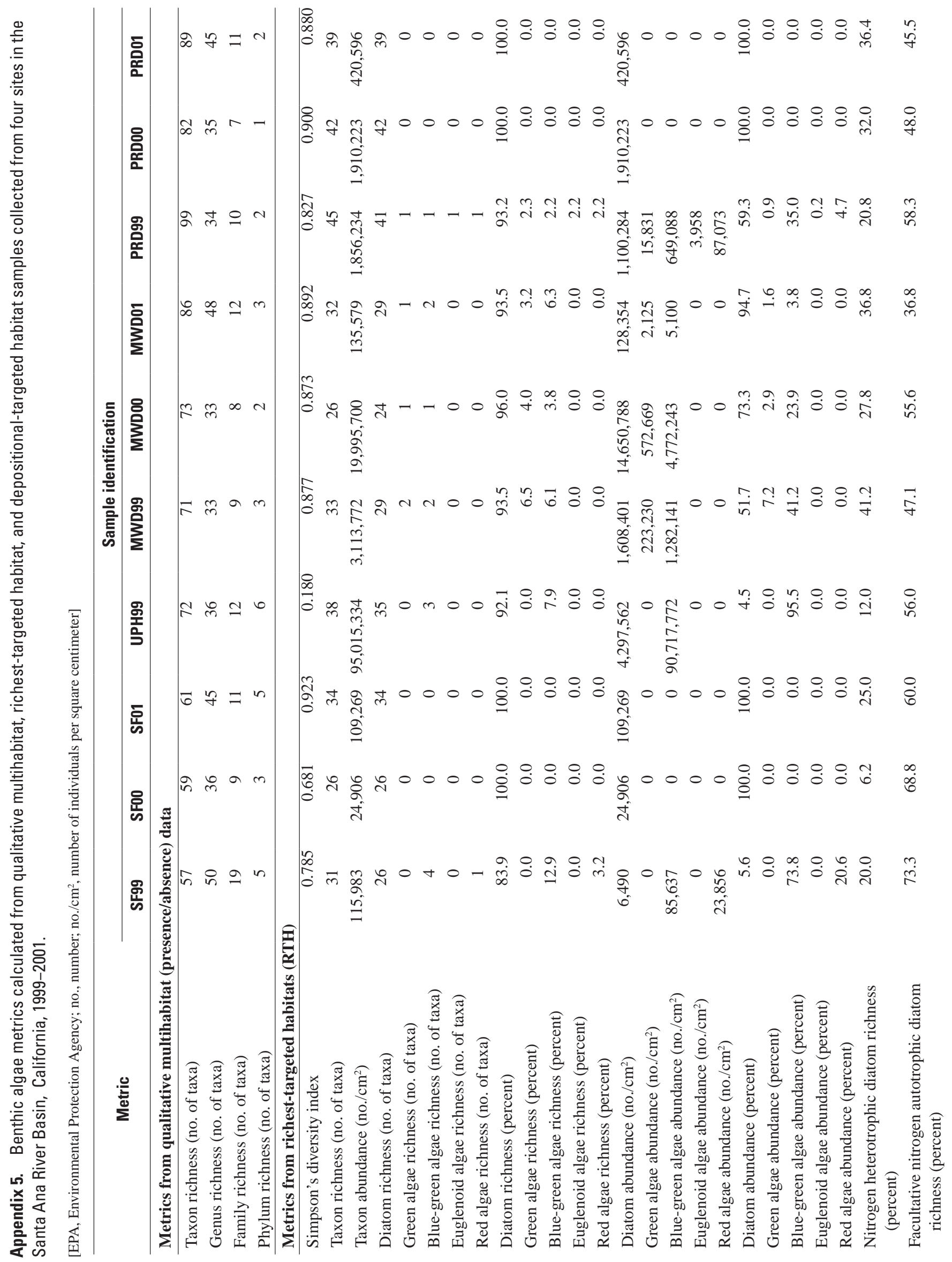




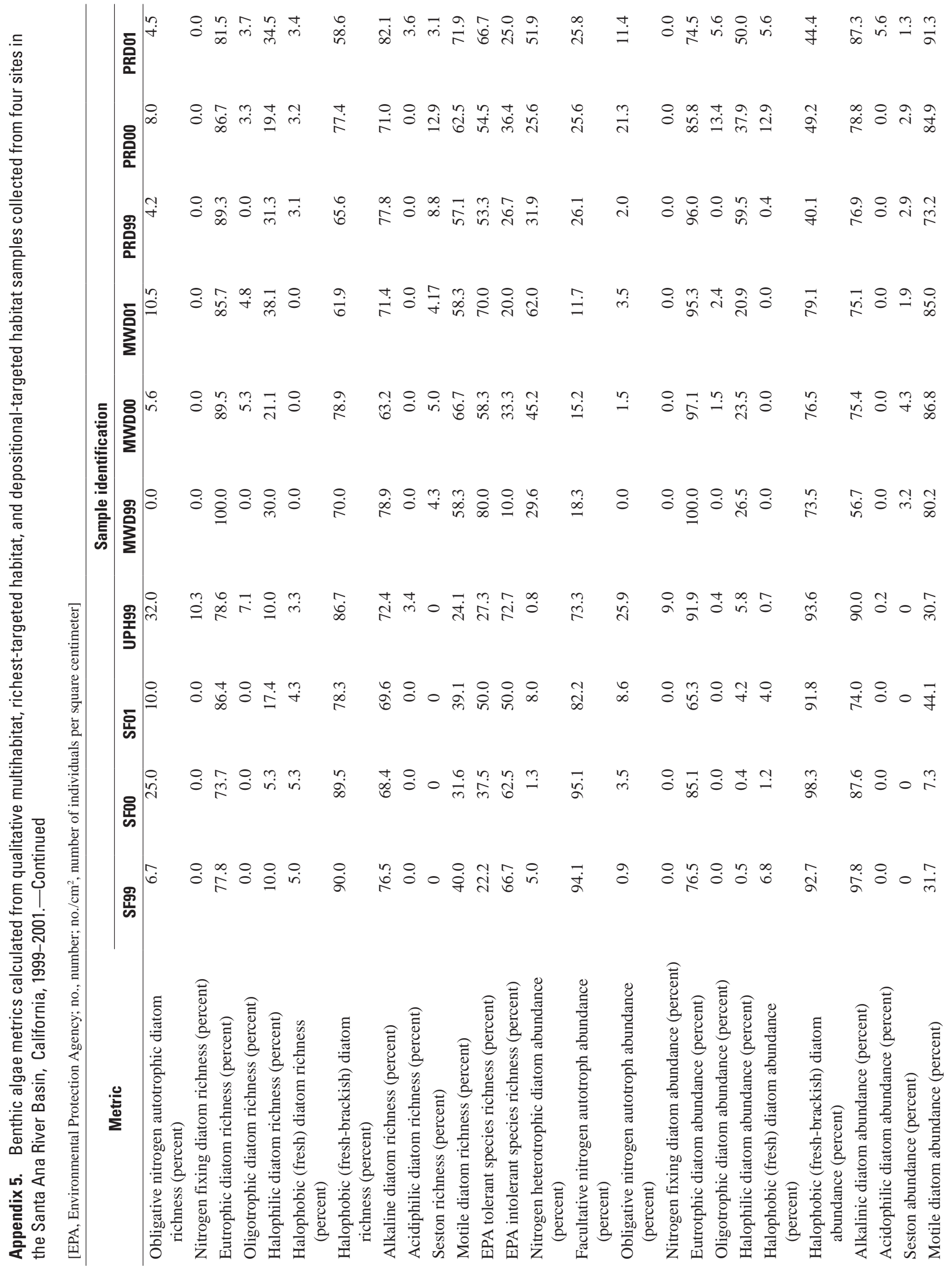




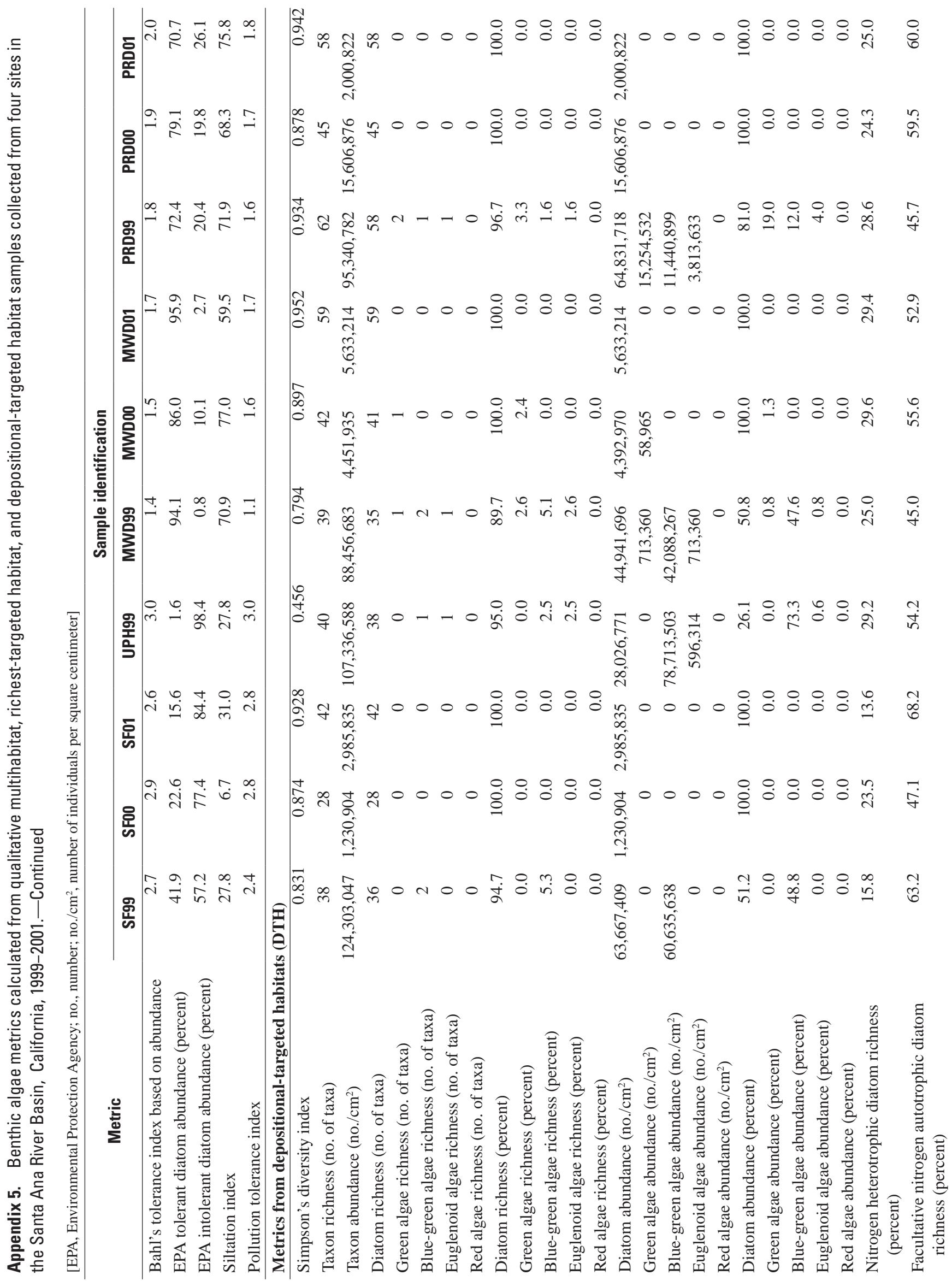




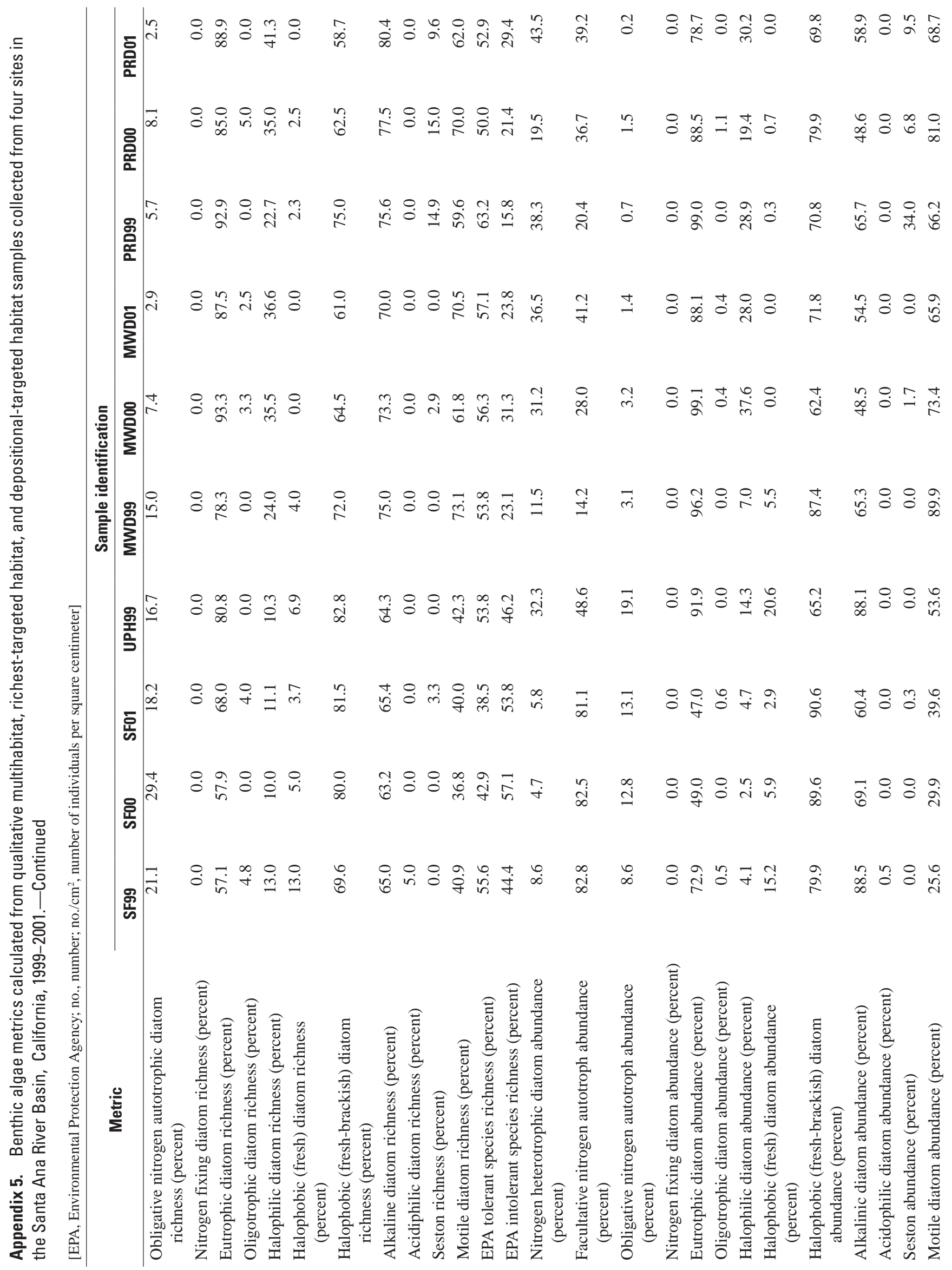




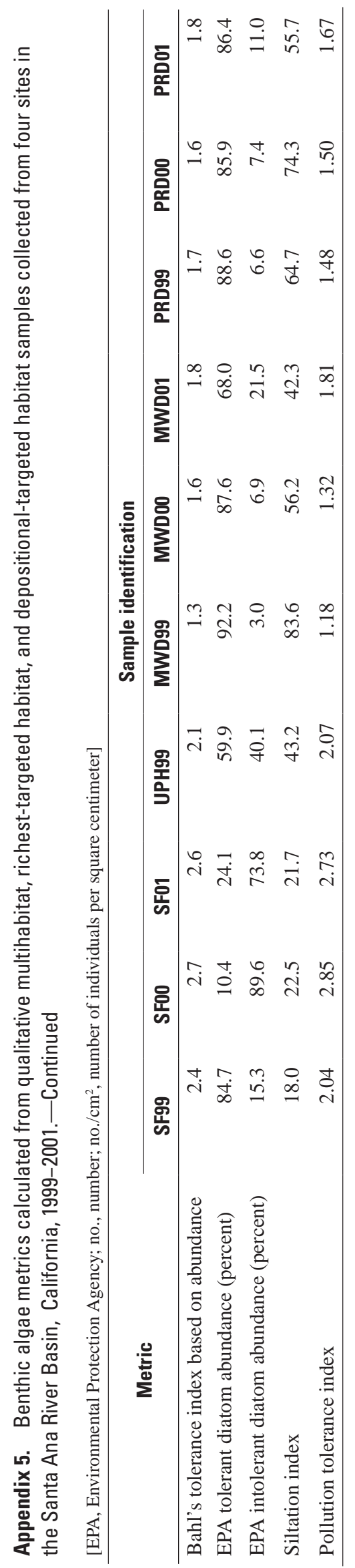




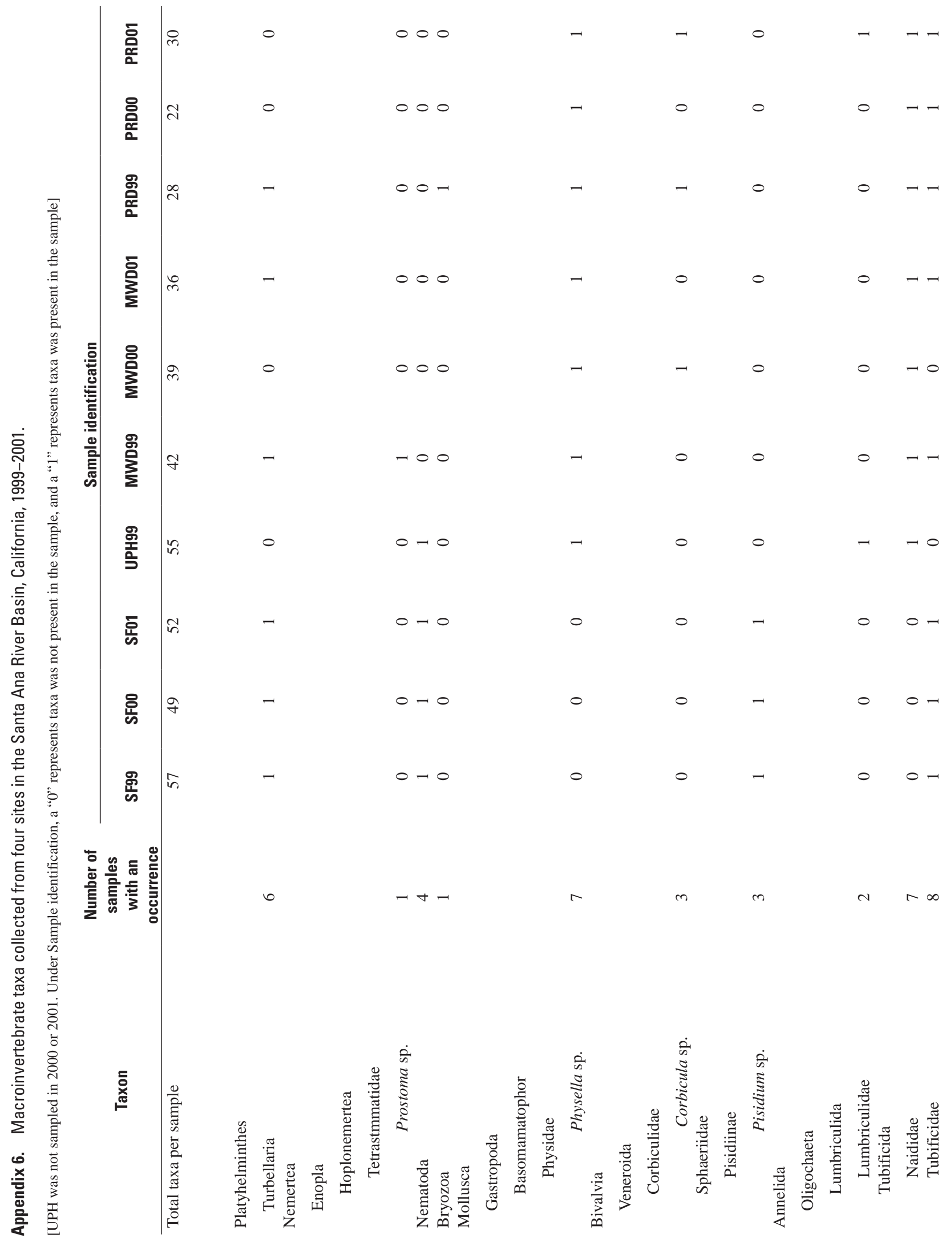




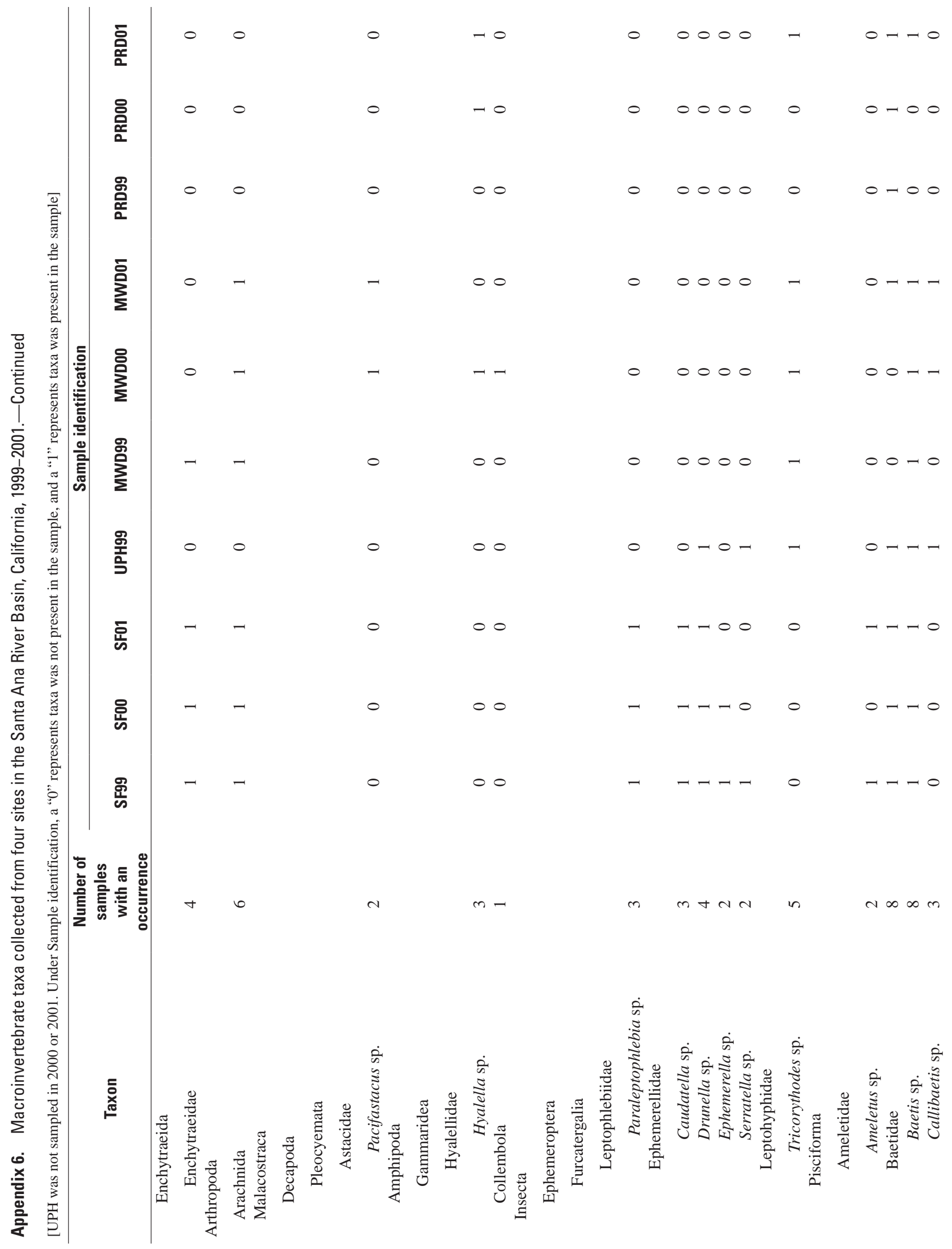




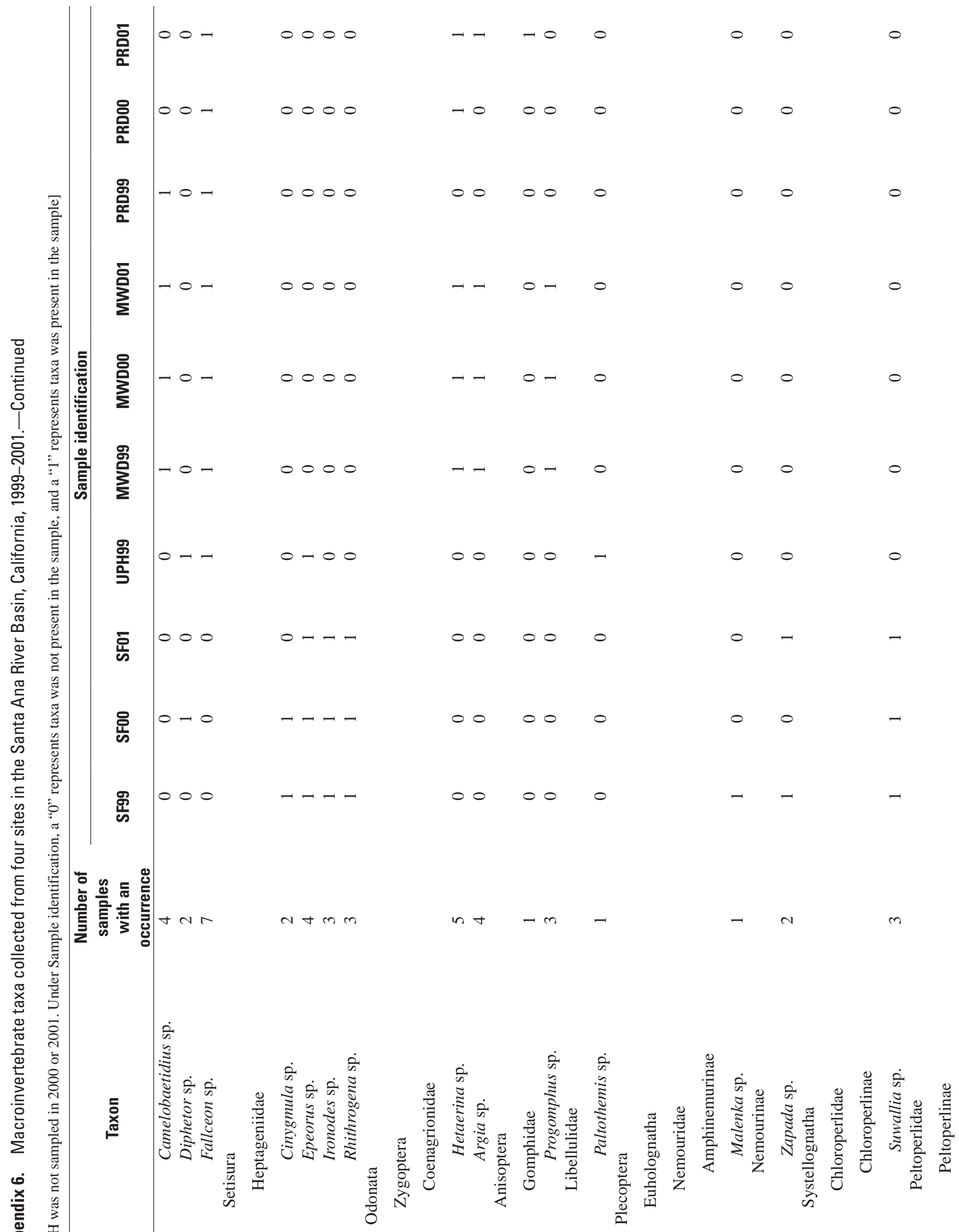




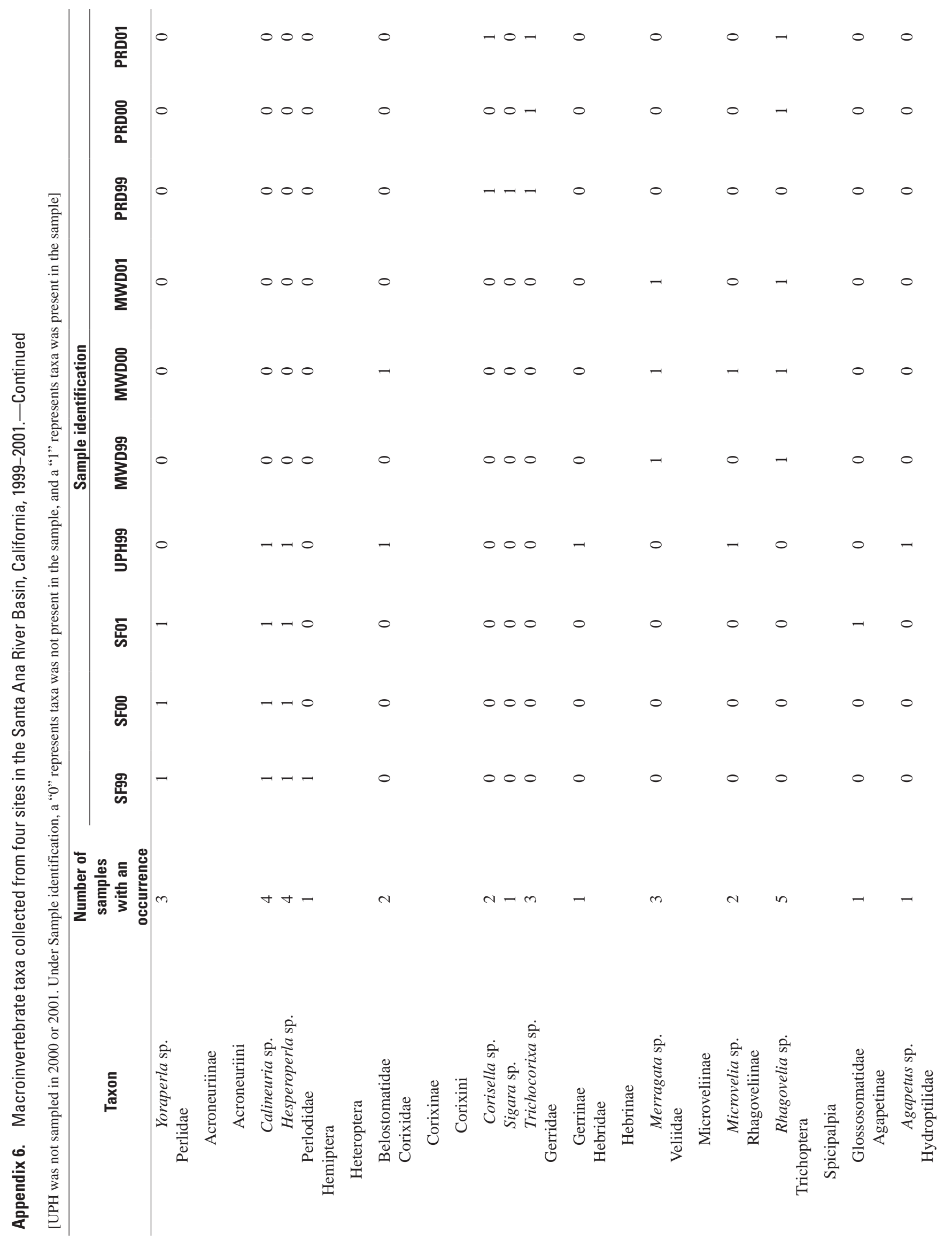




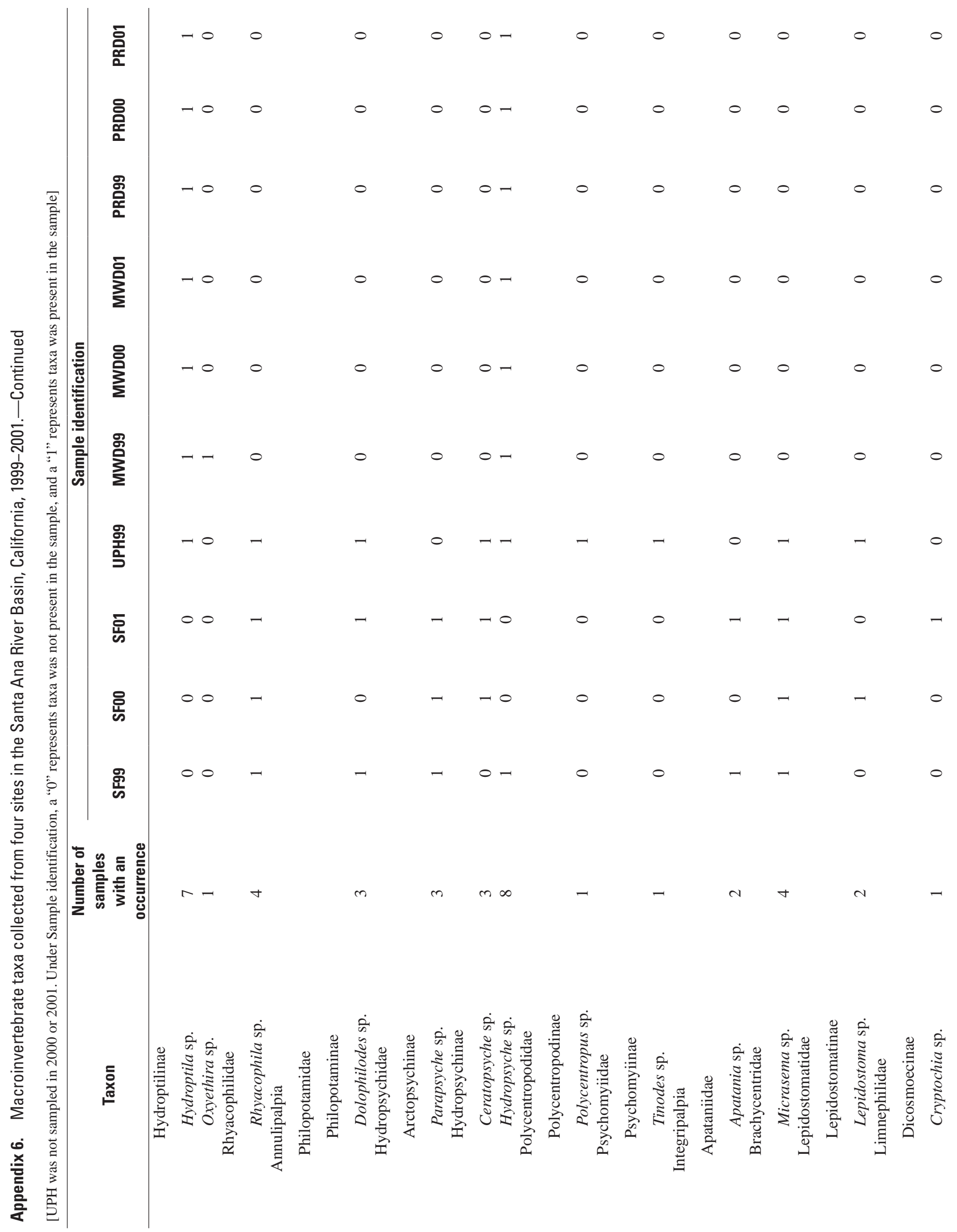




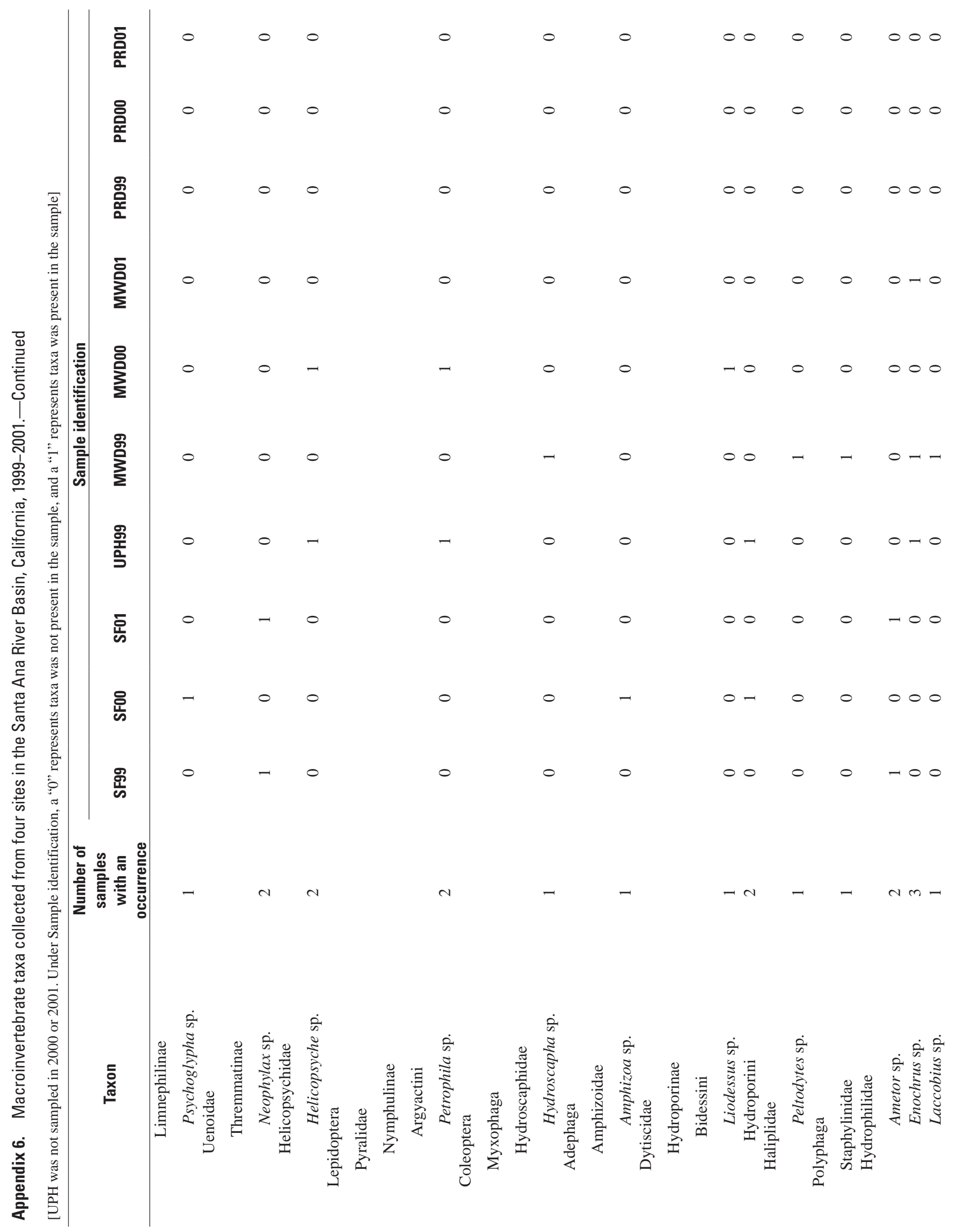




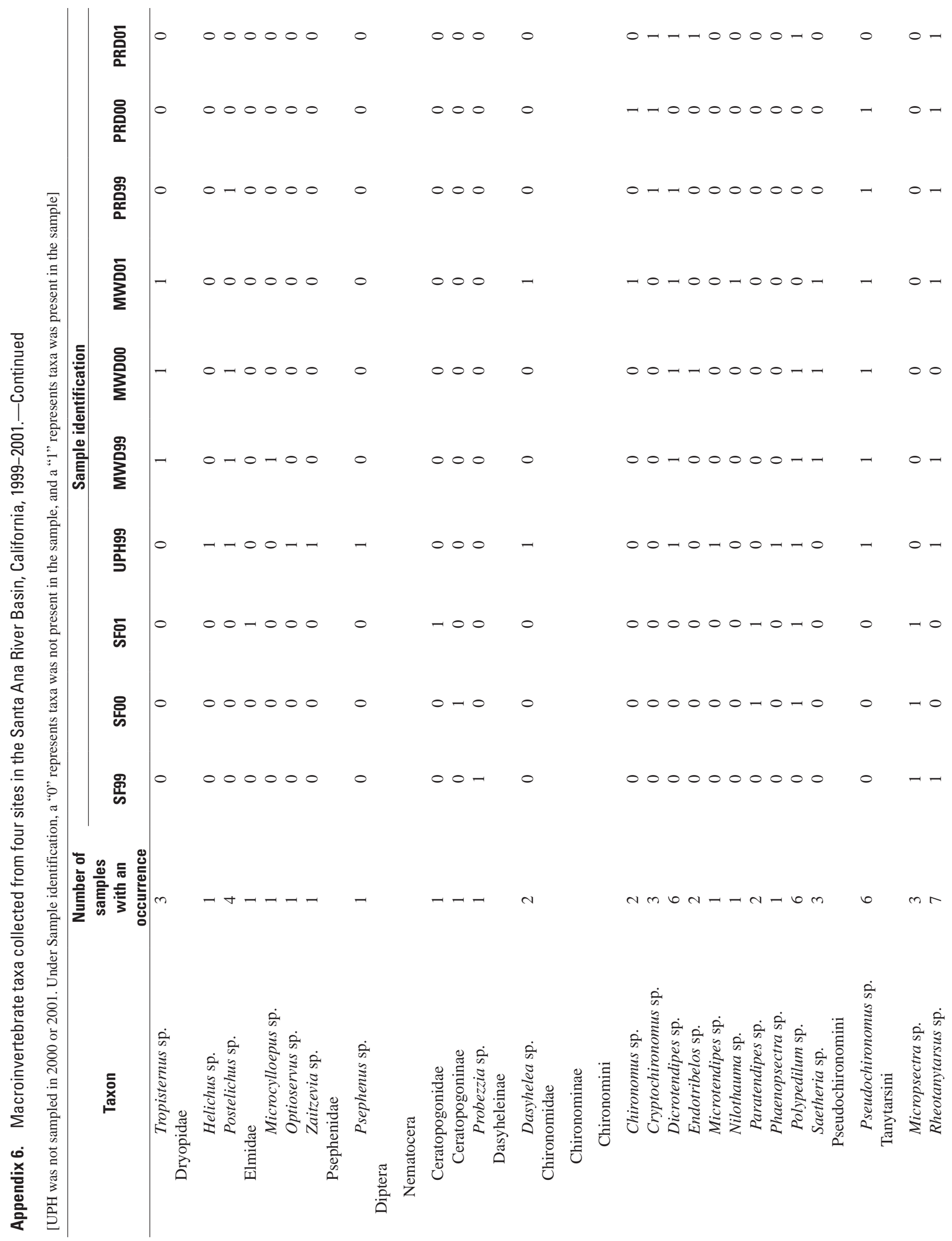




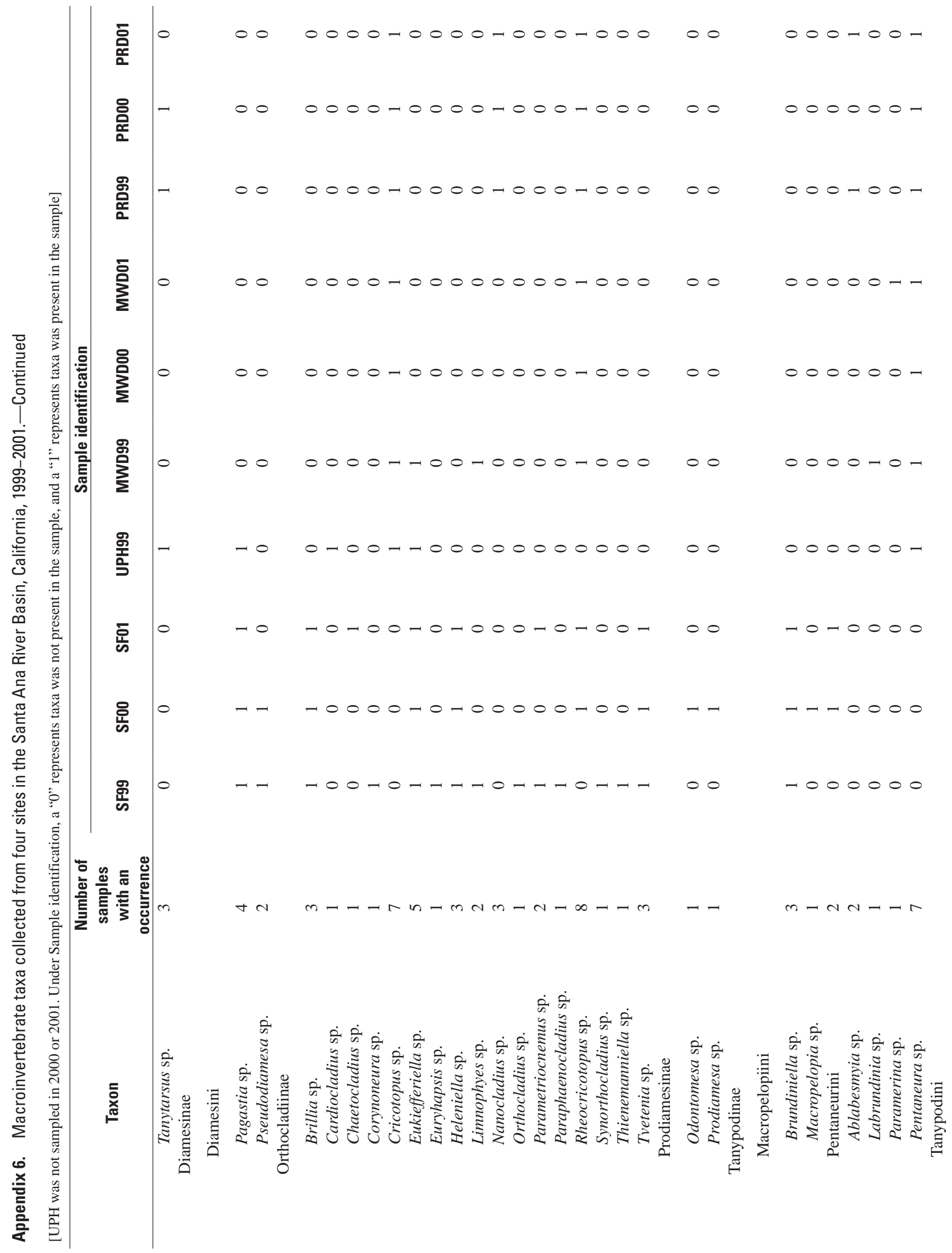




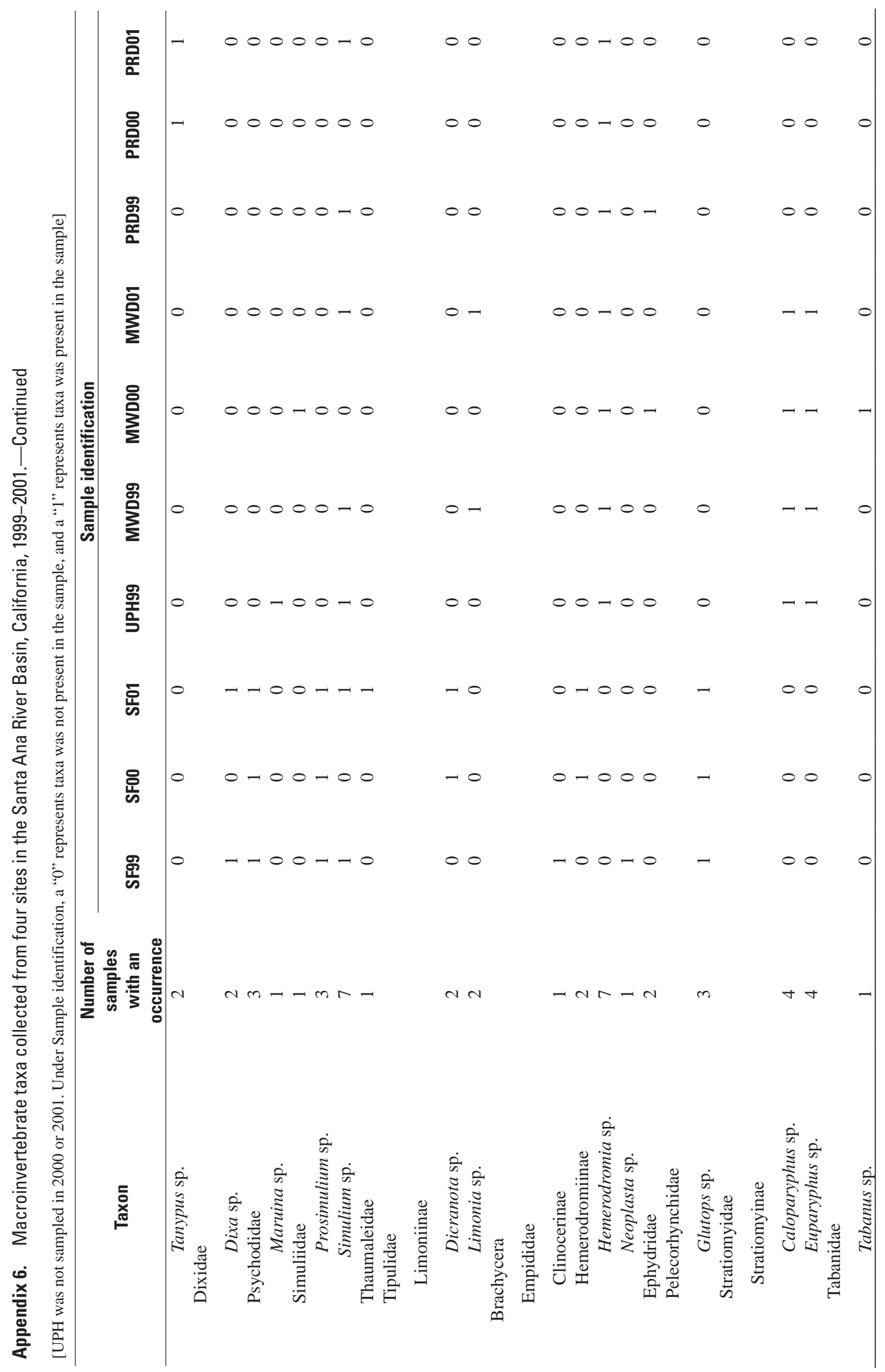




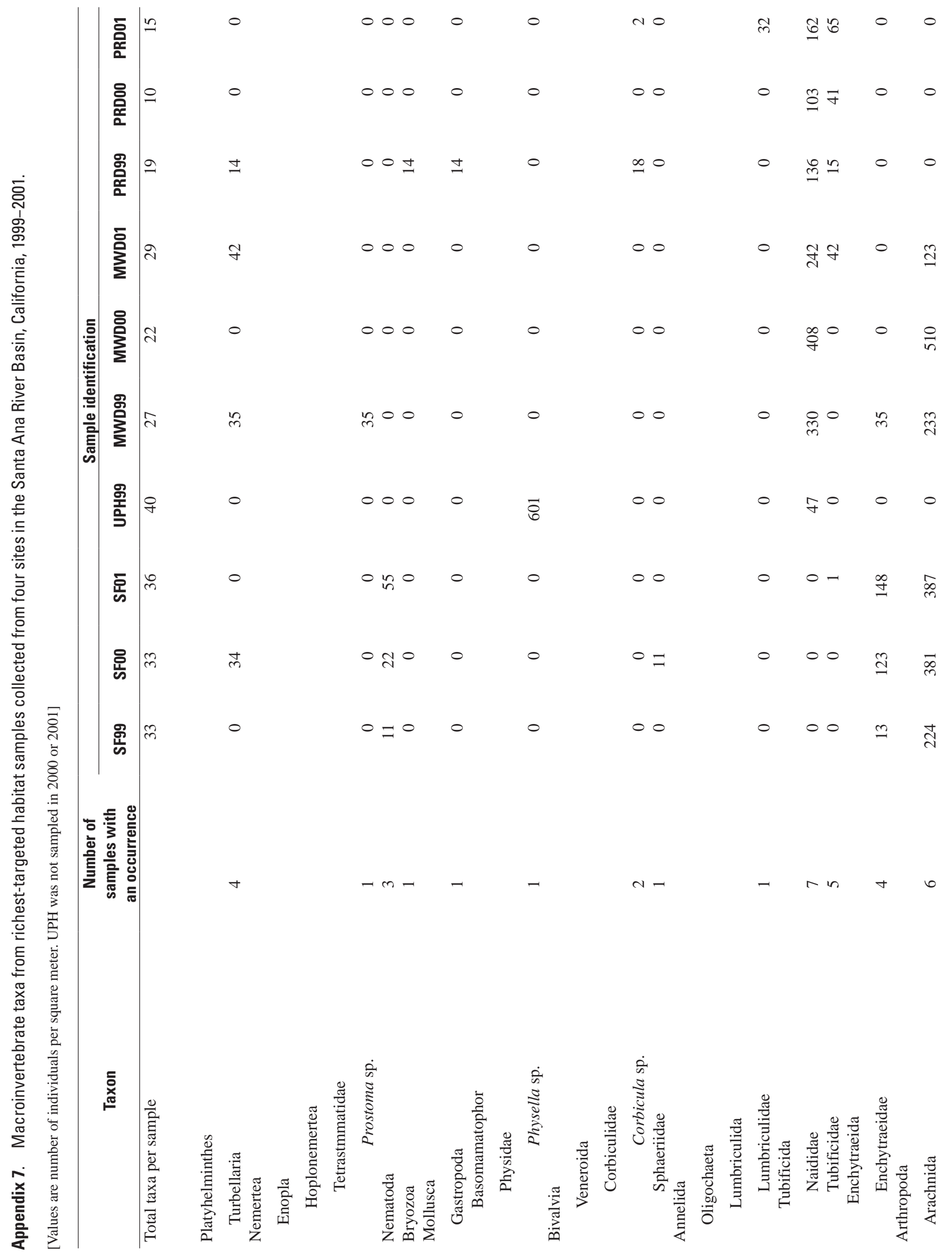




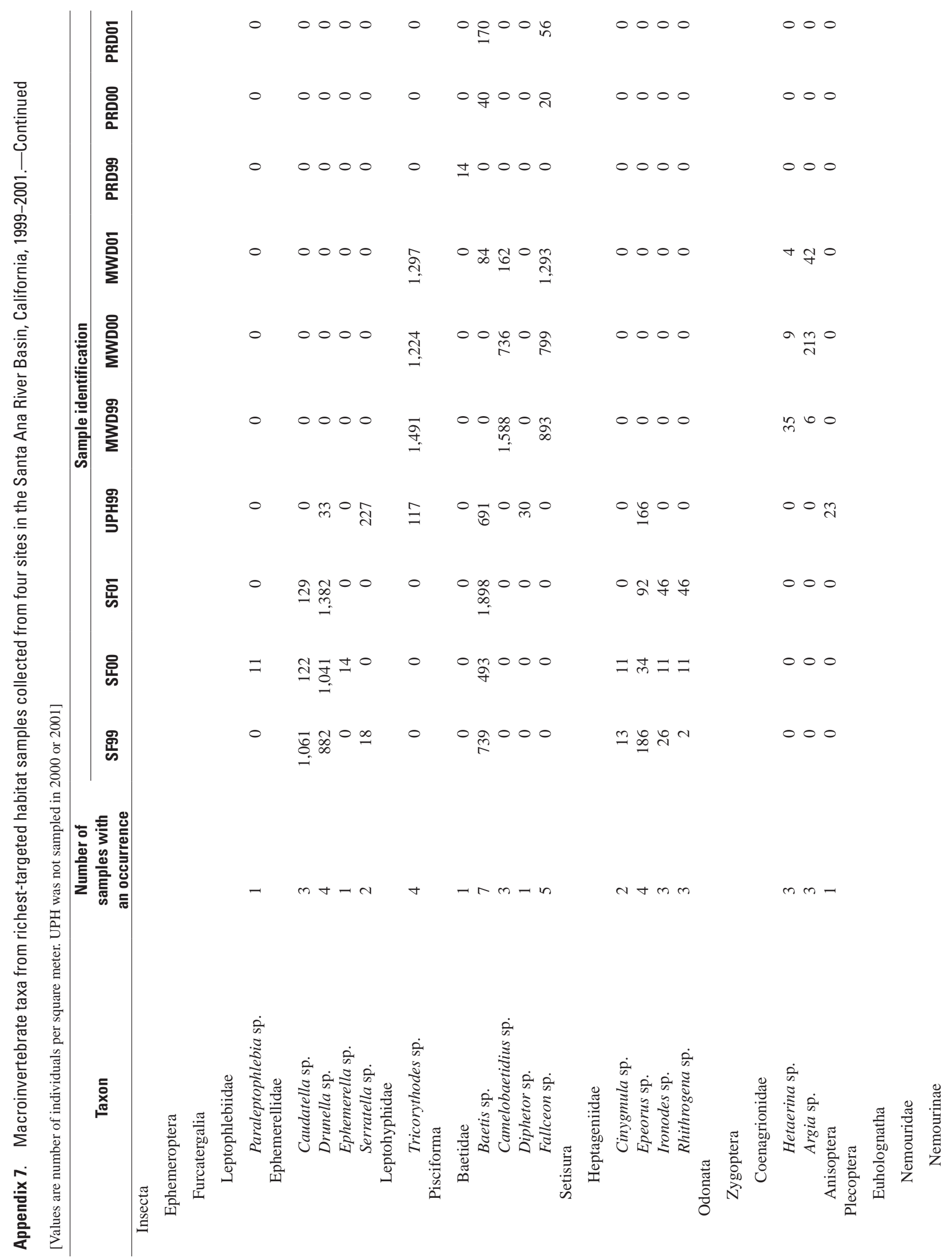




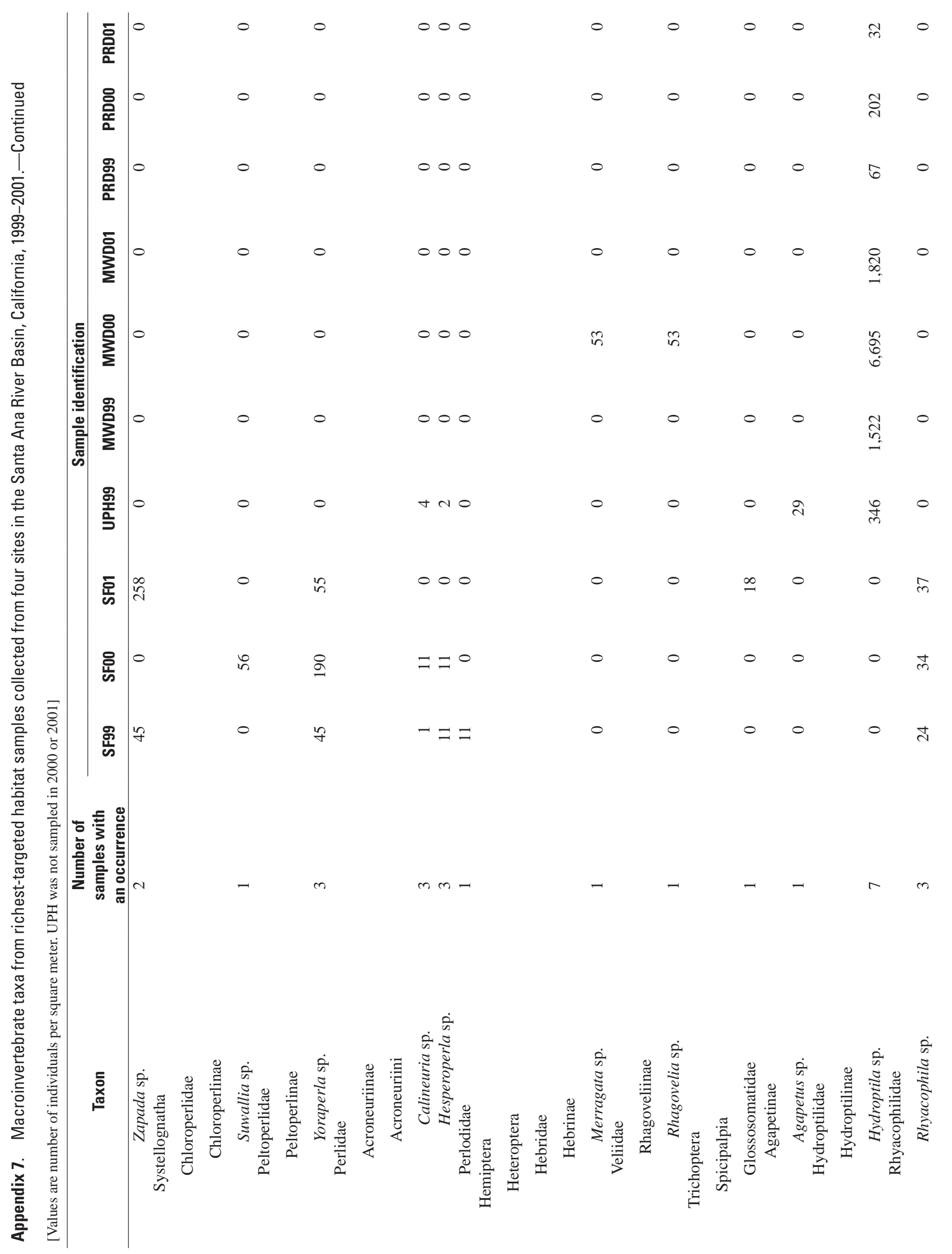




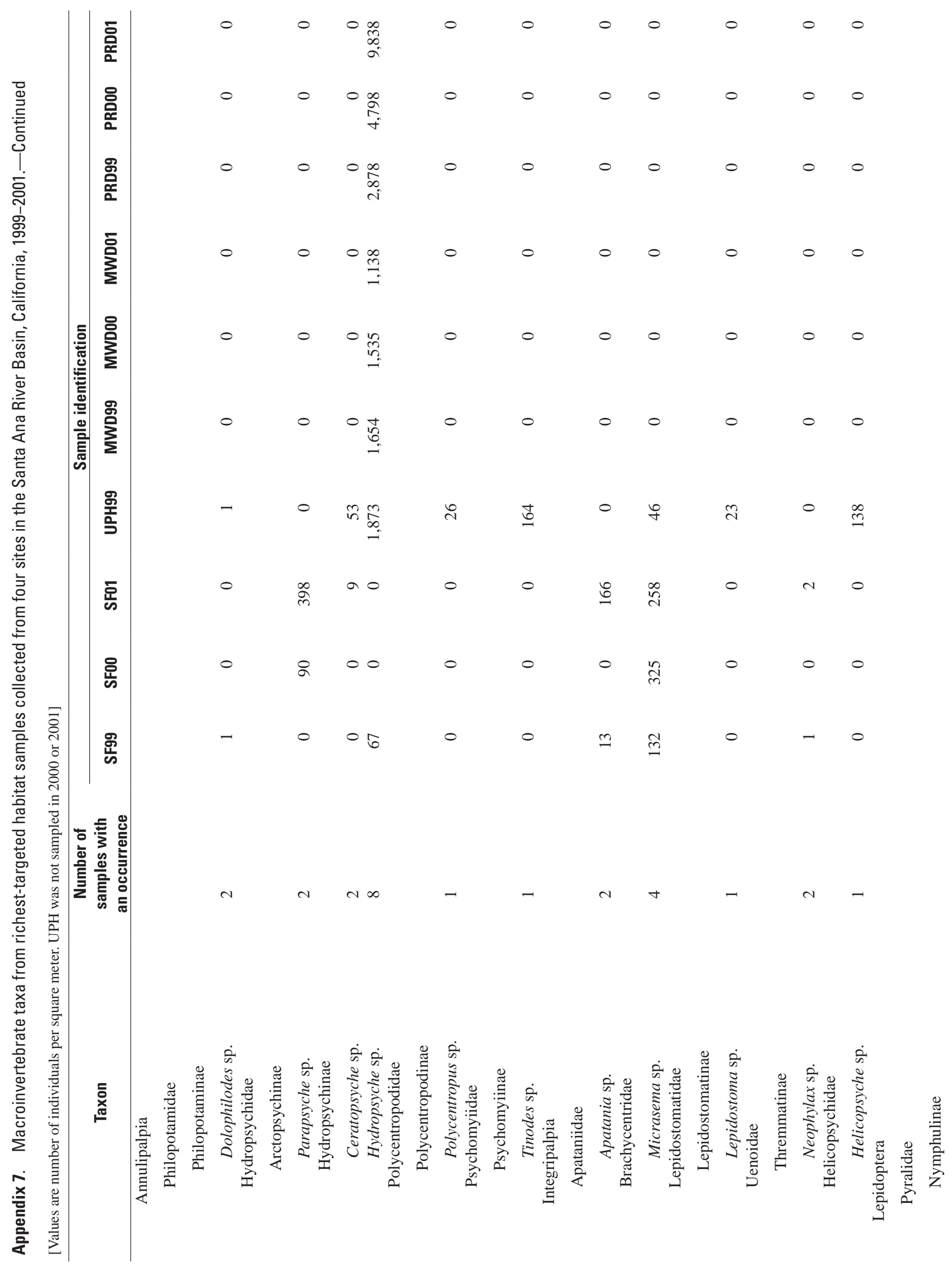




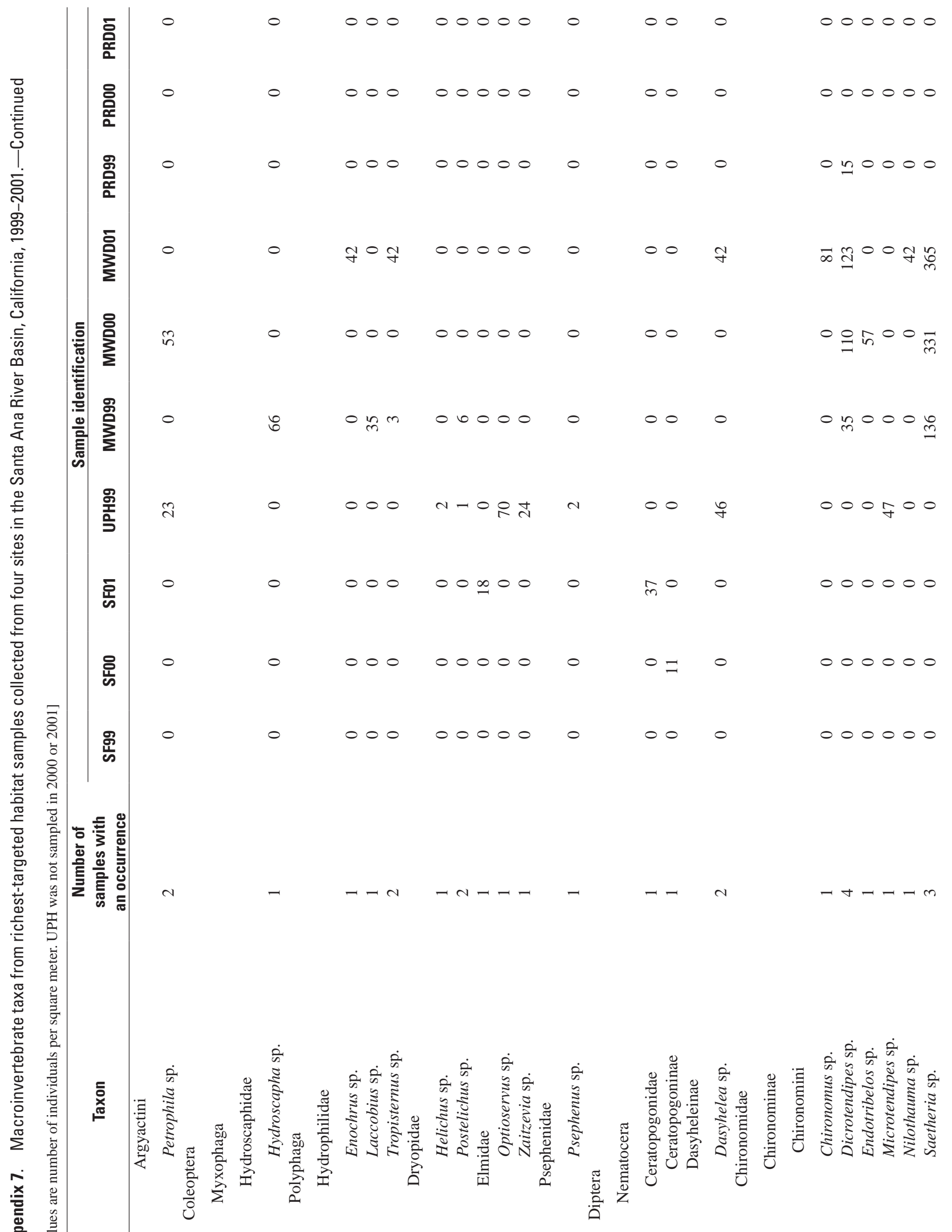




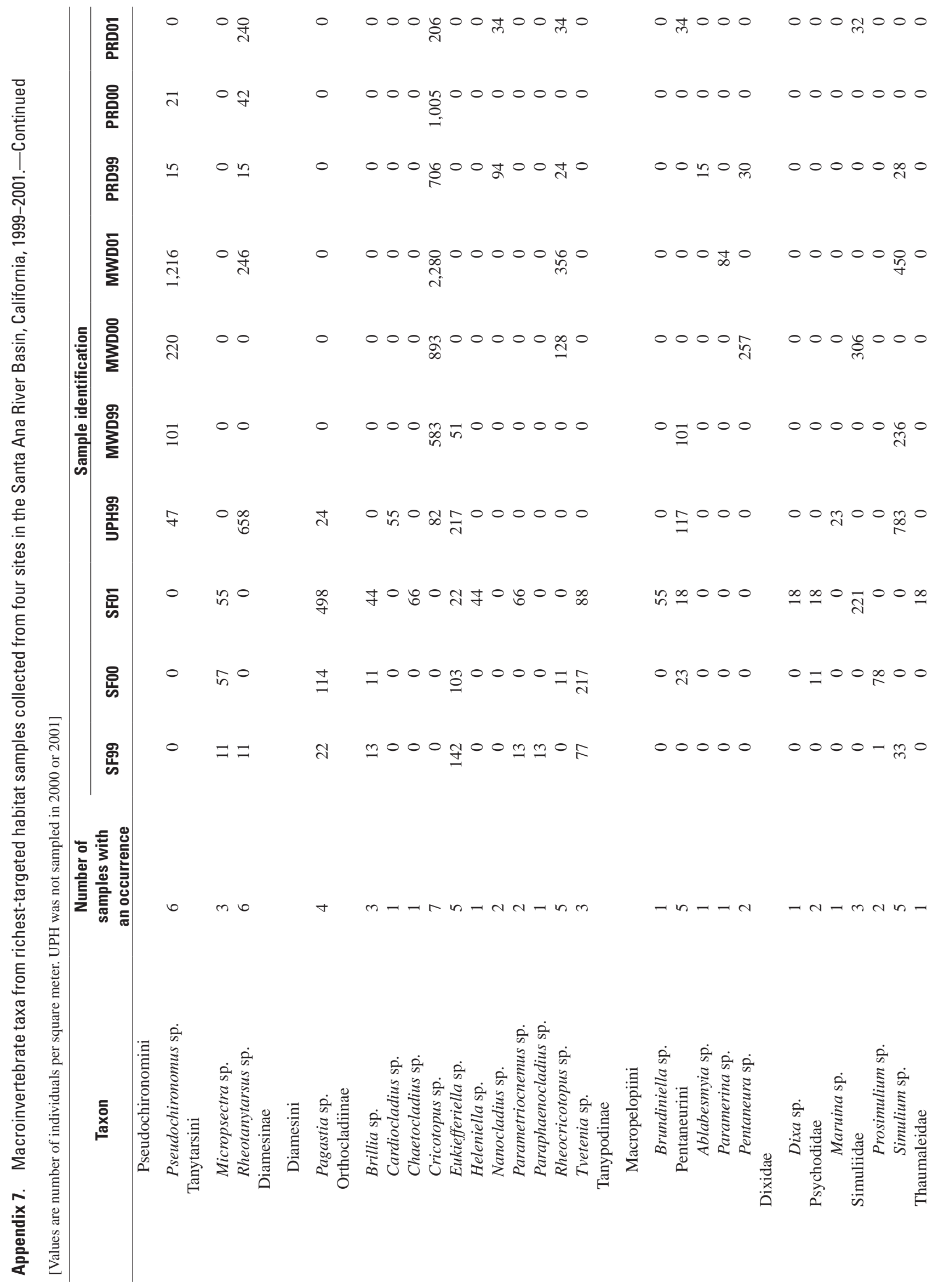




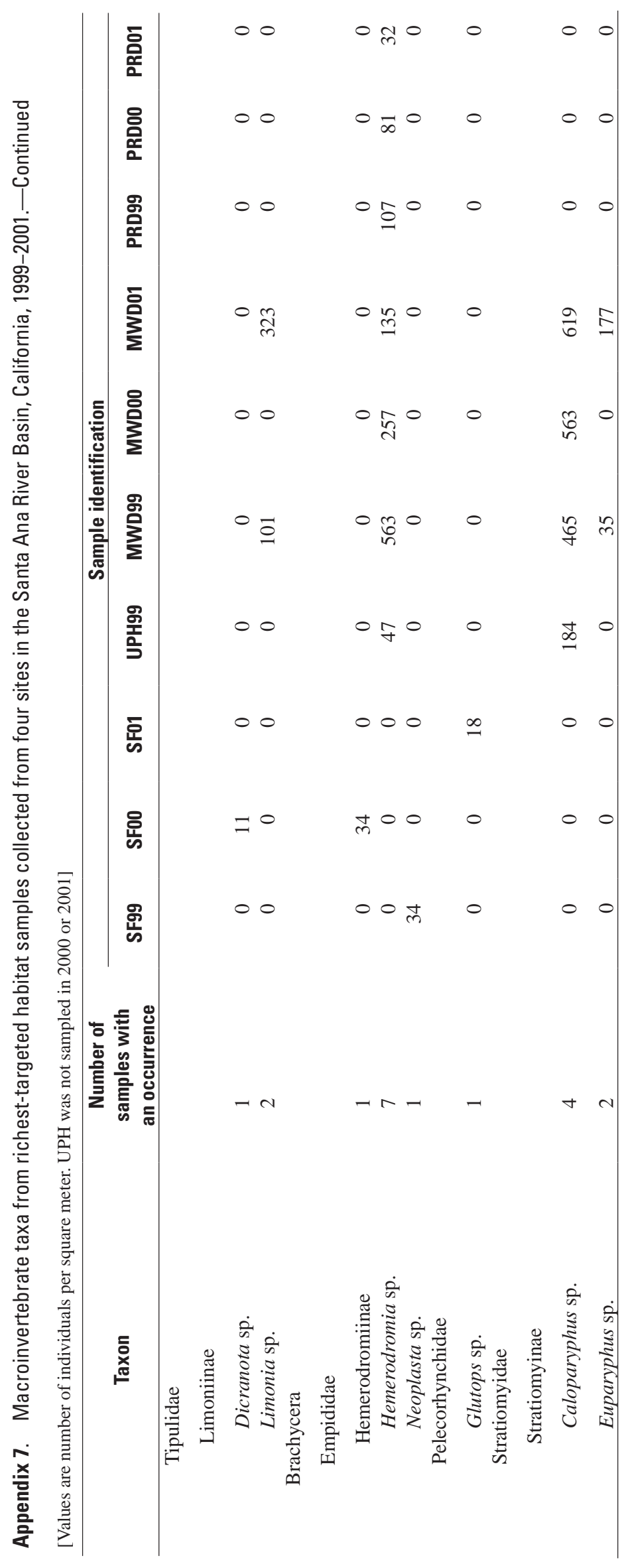




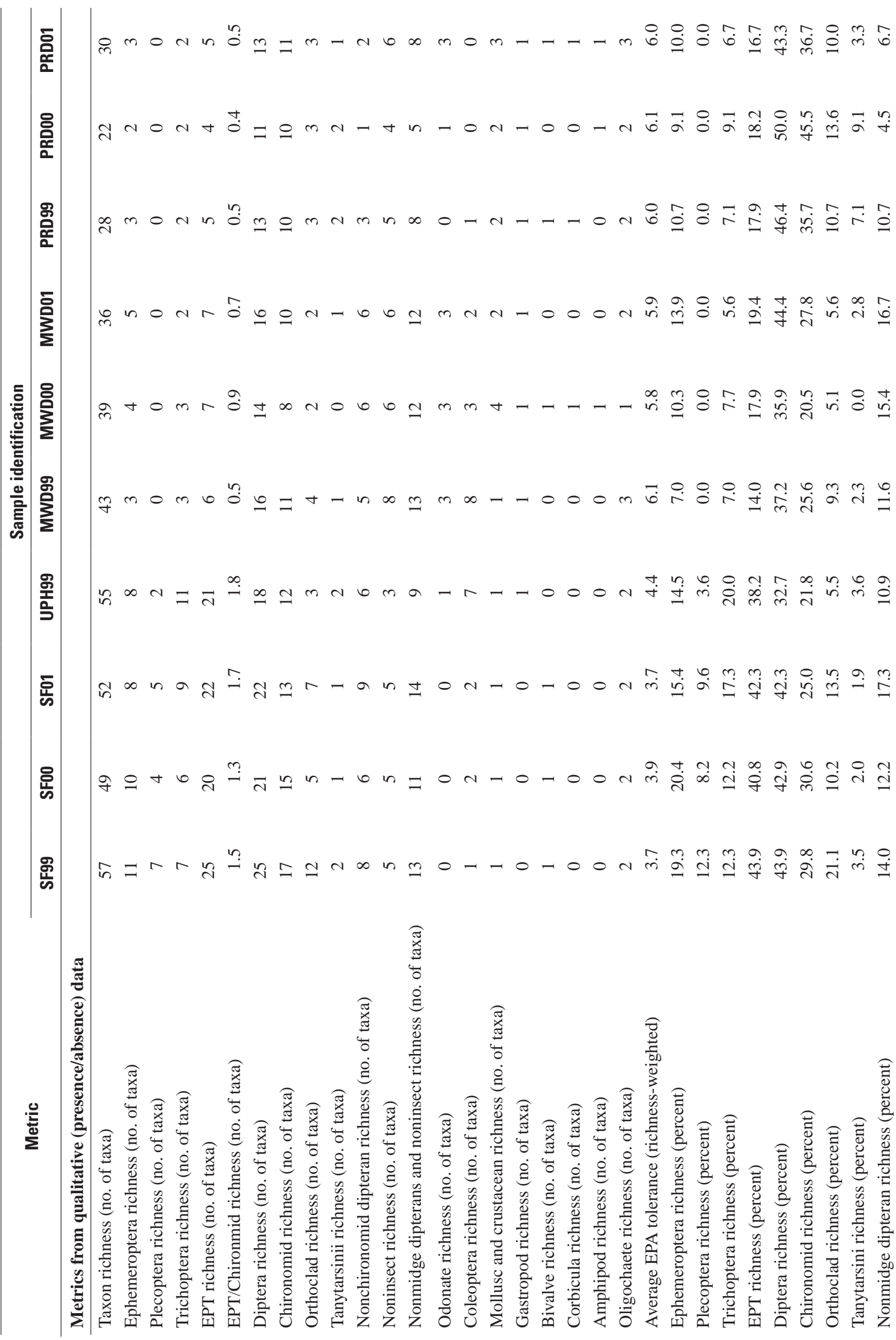




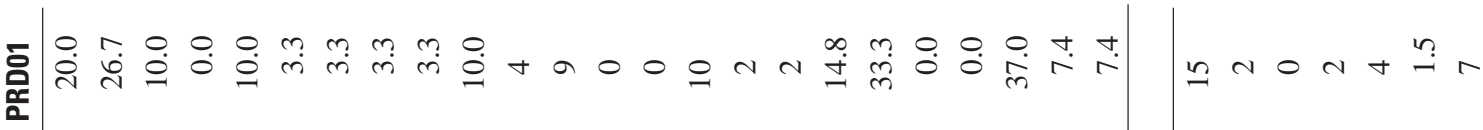

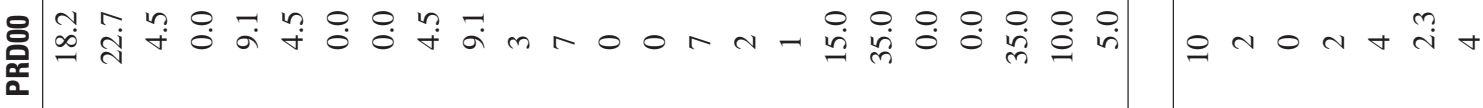

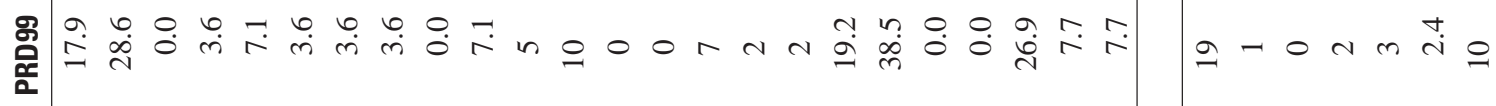

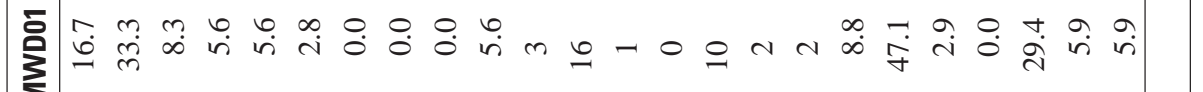

$\hat{i}+0 \times b \stackrel{n}{n} n$

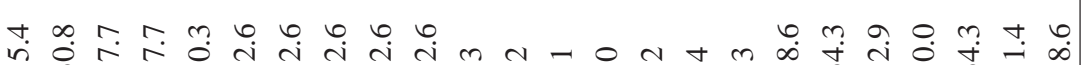

$\operatorname{din} \infty \mathrm{n}$ in $\stackrel{\infty}{0} \circ$

$\sum_{\Sigma}^{8}$

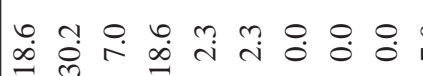

$\stackrel{\circ}{\circ} m$

站的

옹 농

记

$\stackrel{0}{i n}$

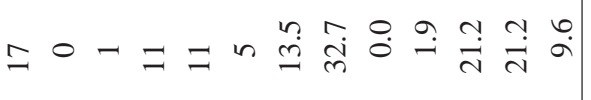

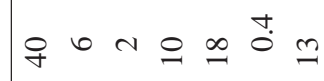

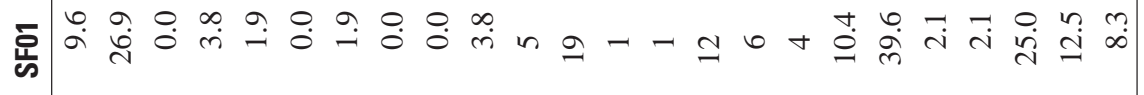

$\operatorname{lon}_{0} \ln \tilde{0}$

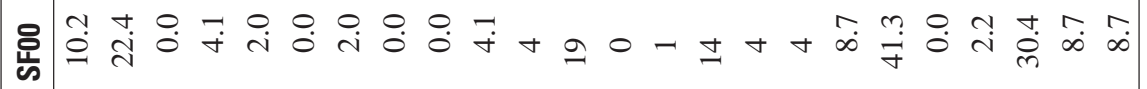
$m a+m \in \hat{0}=$

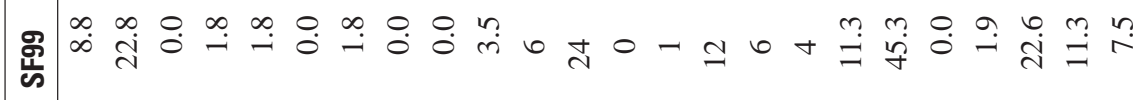

$m \infty$ in $0 \stackrel{\infty}{=} \stackrel{\infty}{=}=$

莣

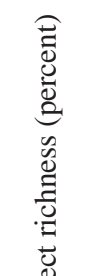

芯

ลn $\operatorname{con} \stackrel{m}{-}=$ 


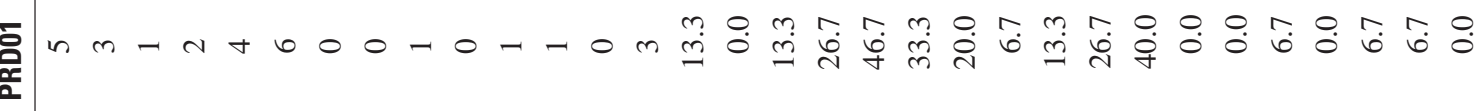

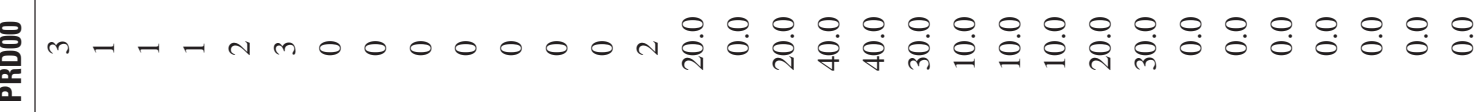

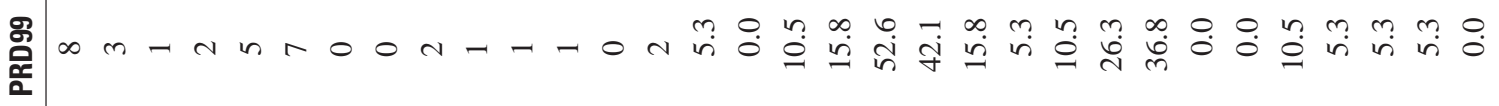

产a $\mid-0+0$ N

Nom n n n o o o o o -

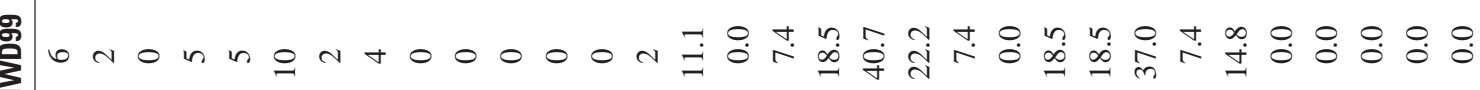

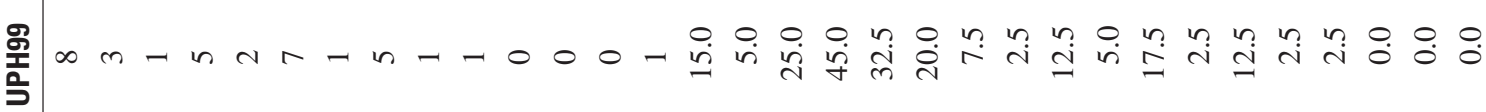

递自 0 -

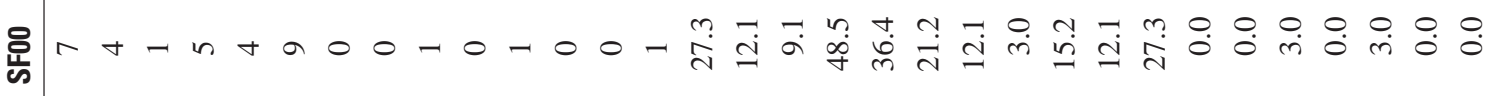

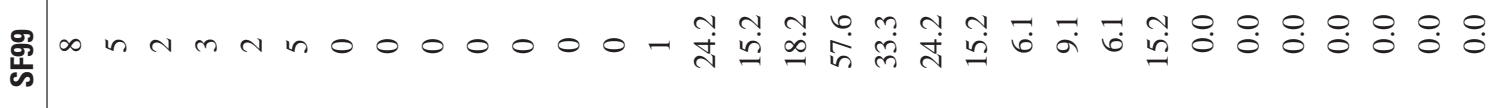

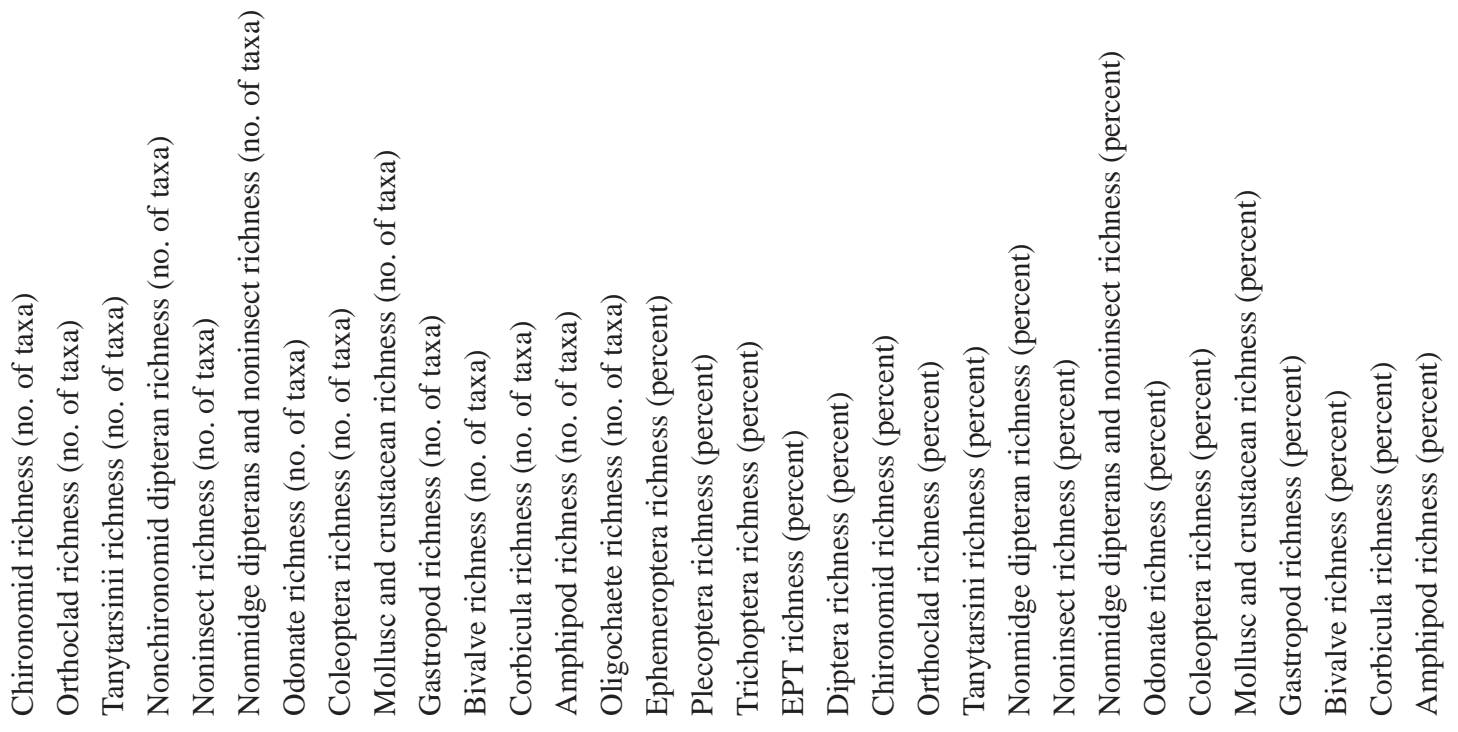




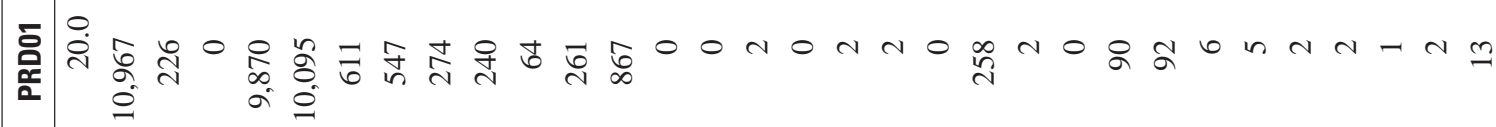

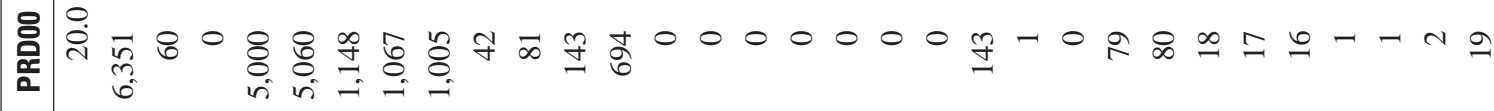

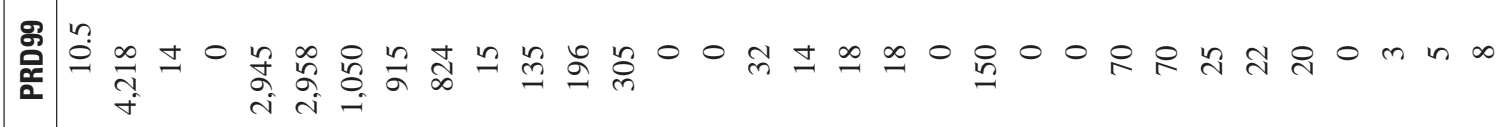

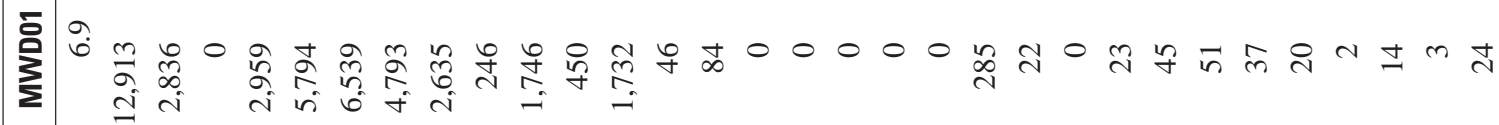

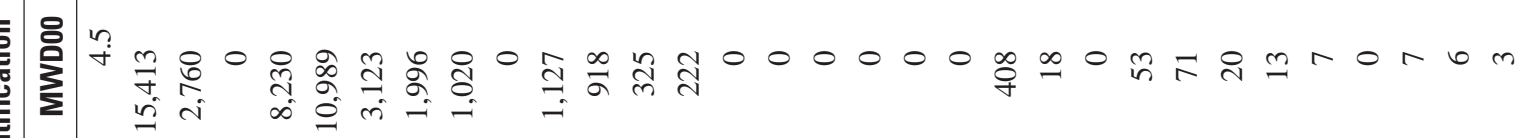

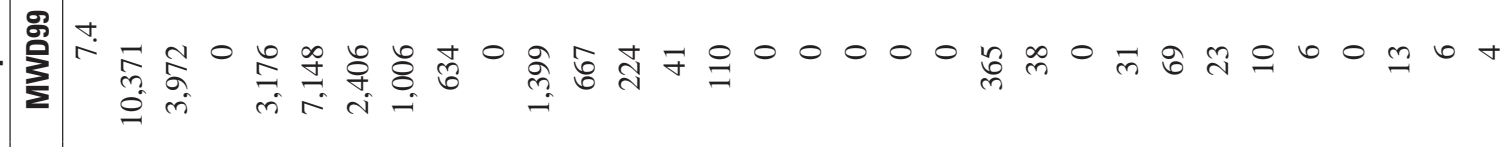

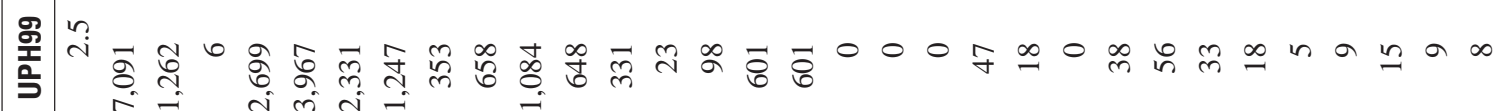

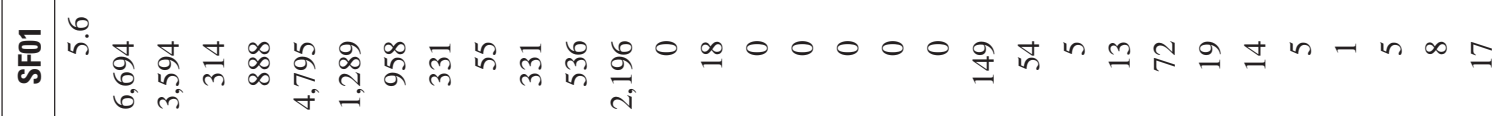

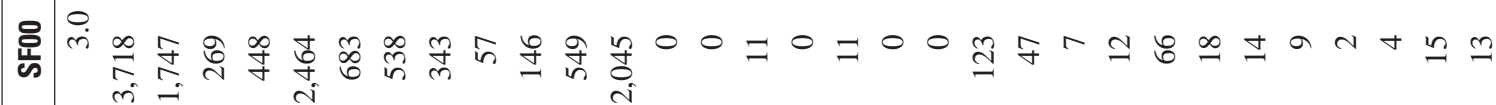

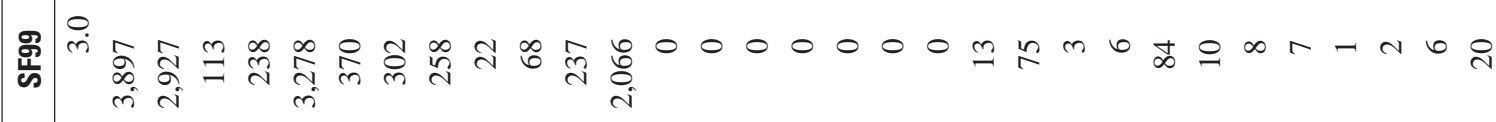

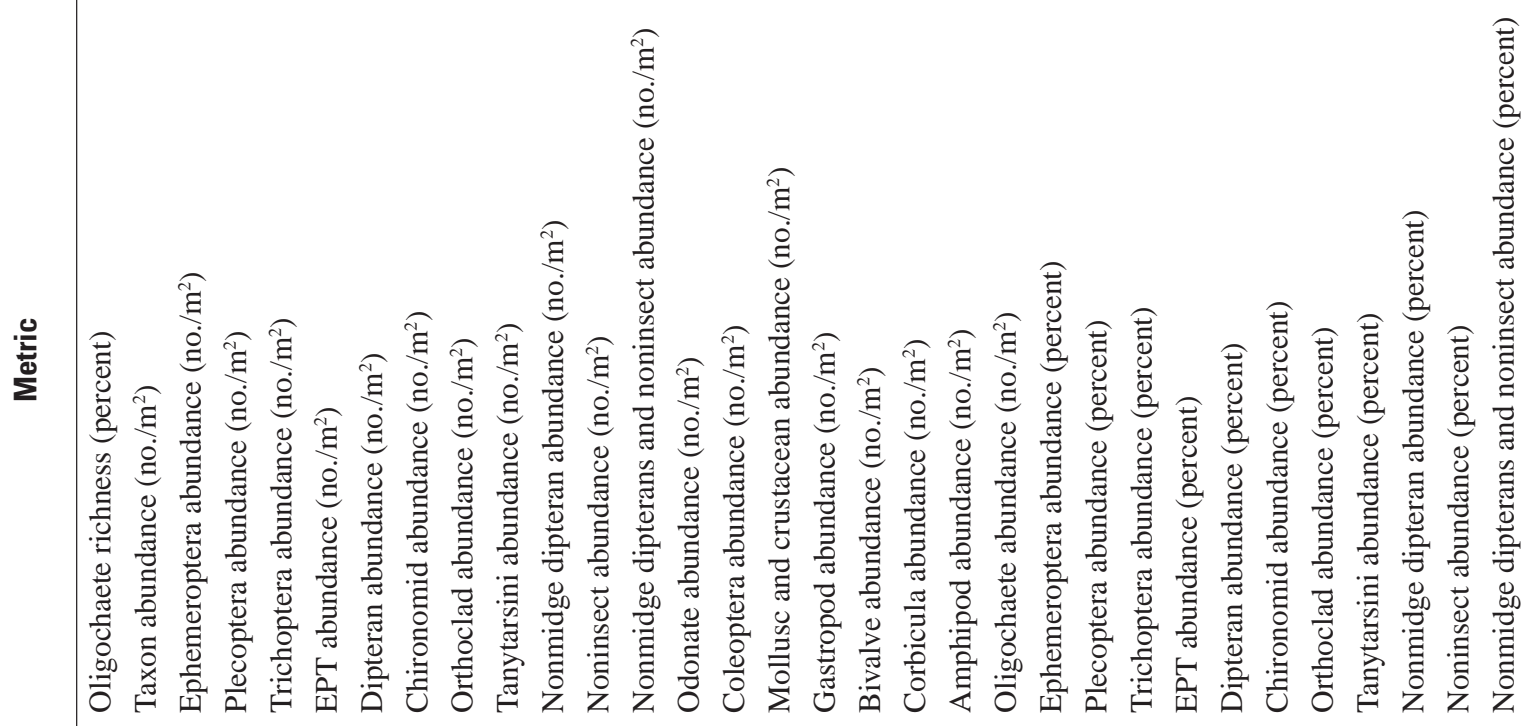




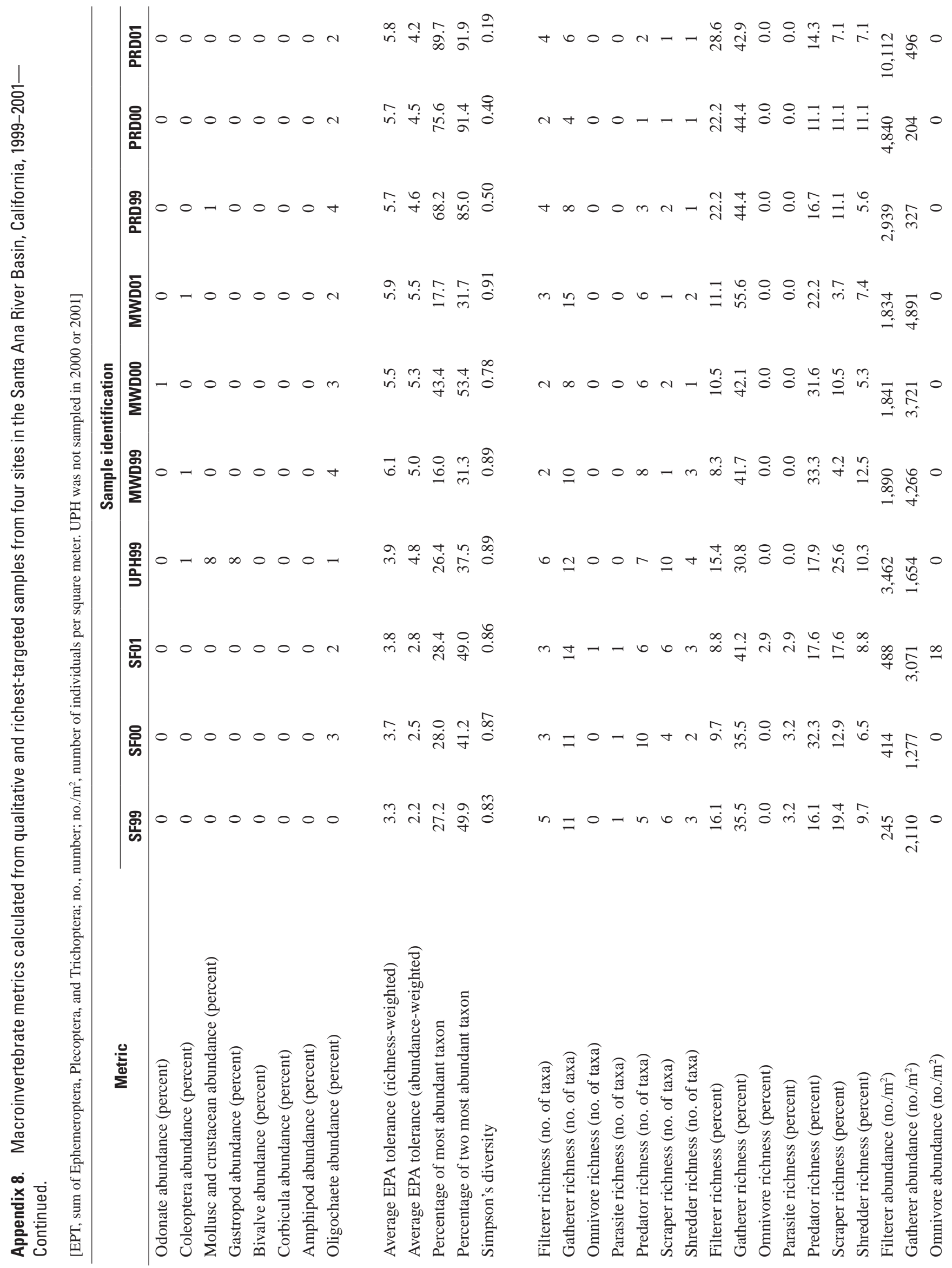




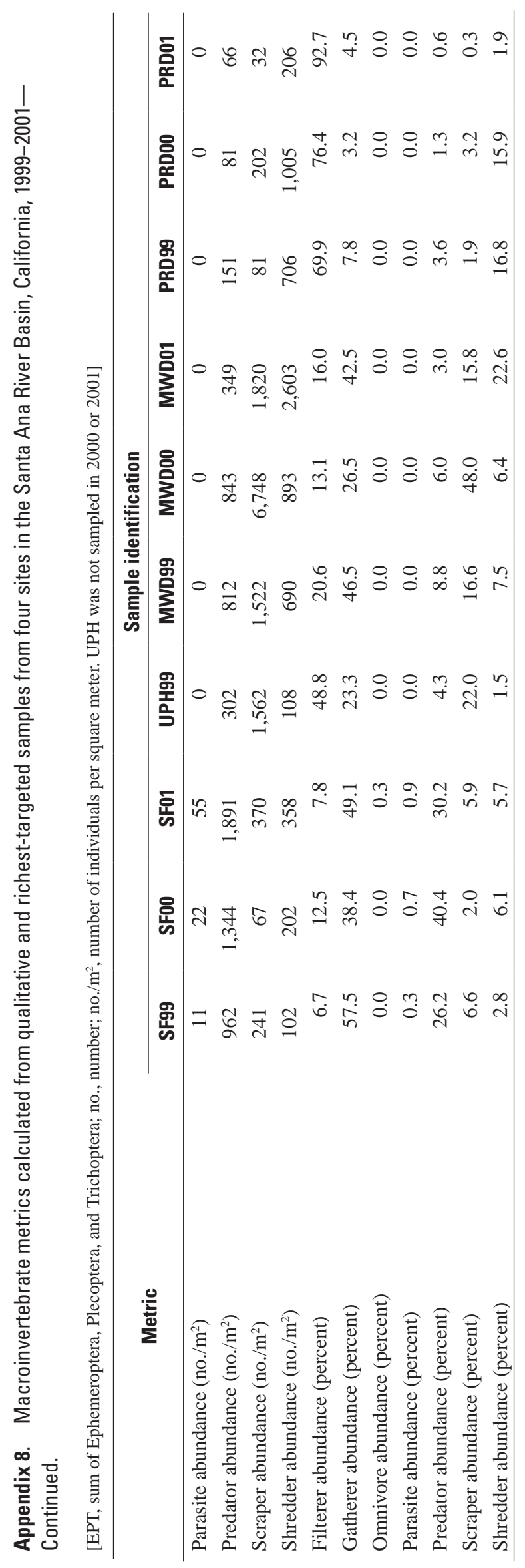




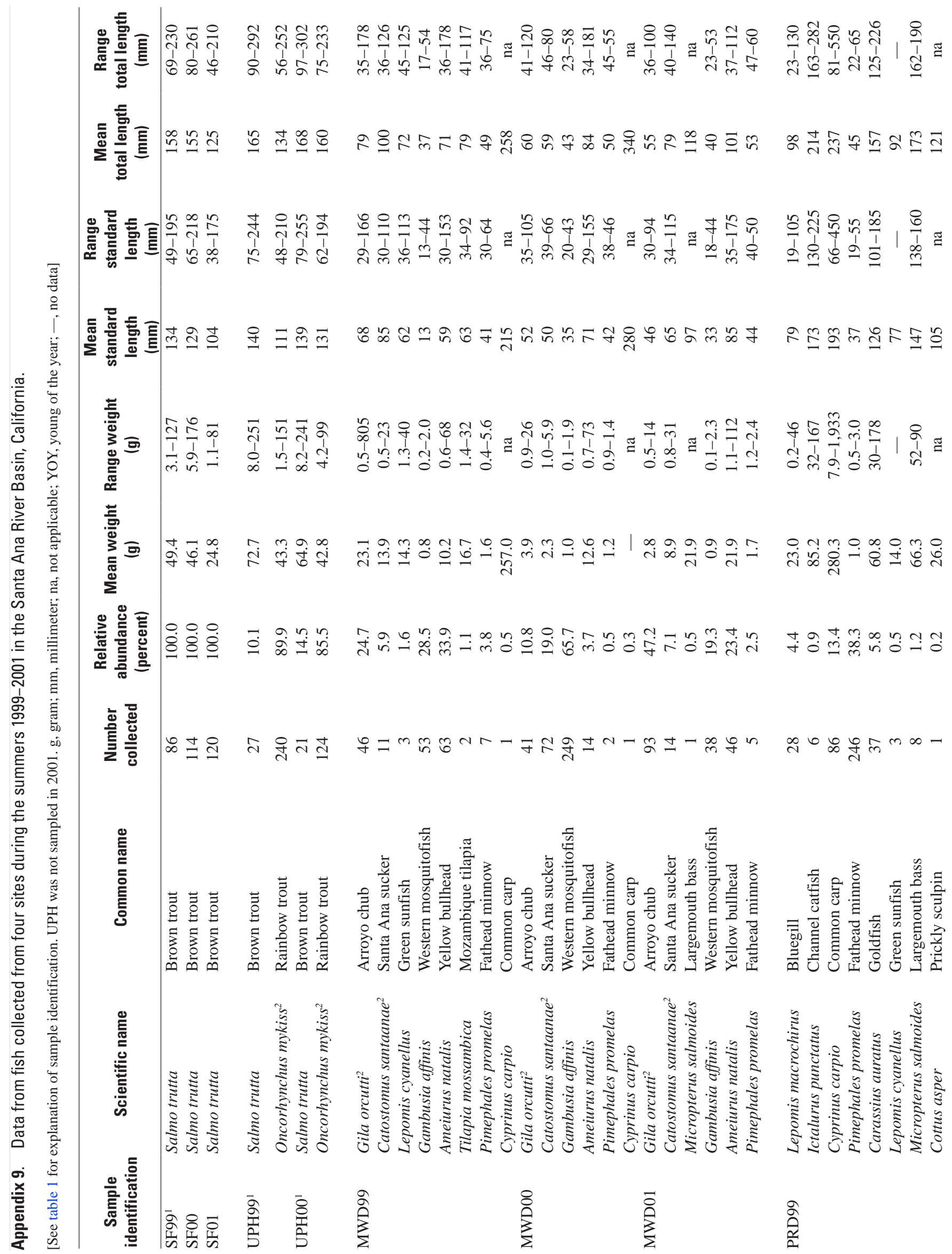




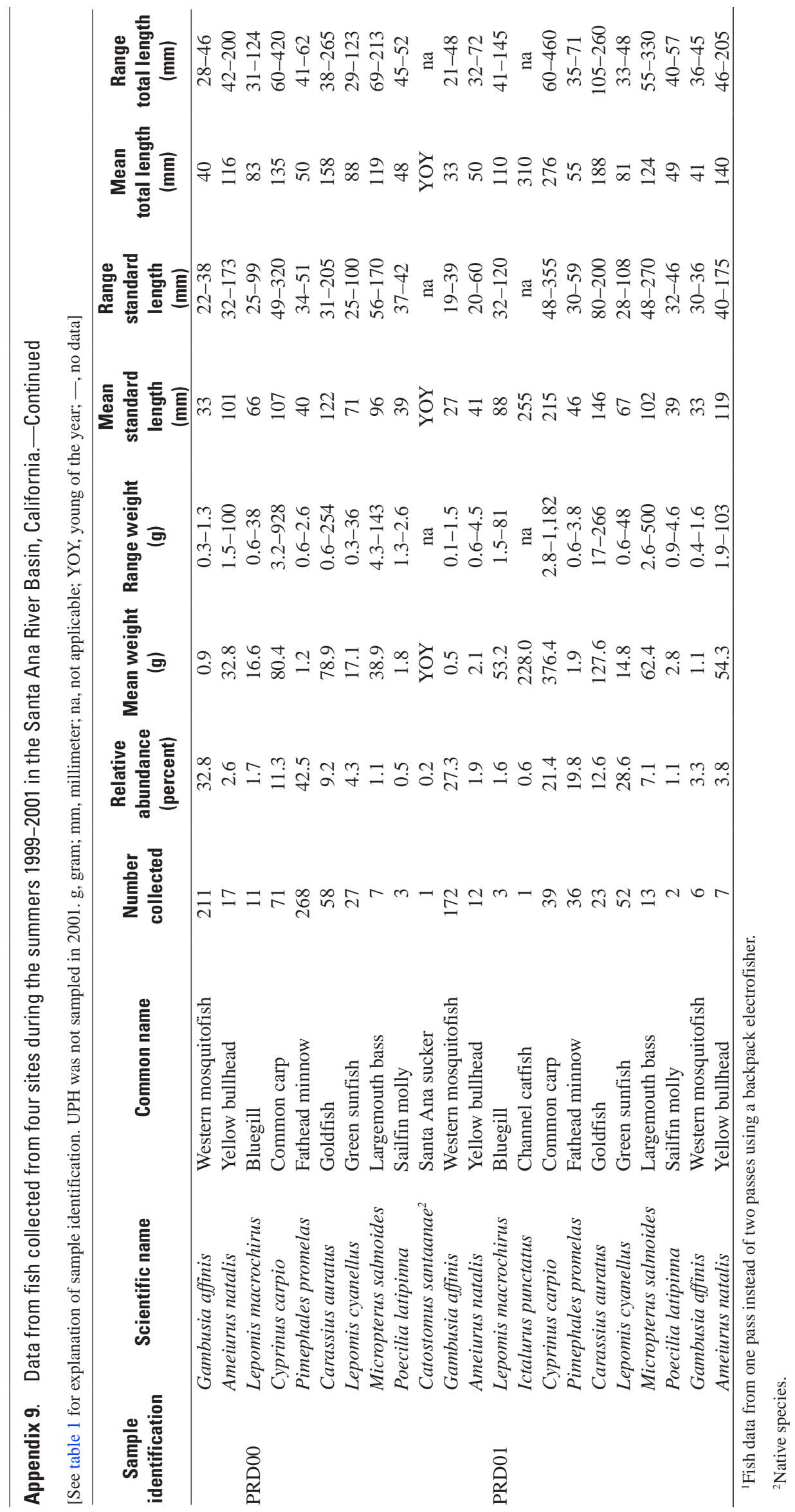


Manuscript approved for publication, July 17, 2008

Prepared by the USGS Publishing Network,

Publishing Service Center, Sacramento, California

Susan Davis

Phil Contreras

For more information concerning the research in this report, contact the California Water Science Center Director,

U.S. Geological Survey, 6000 J Street

Sacramento, California 95619

http://ca.water.usgs.gov 


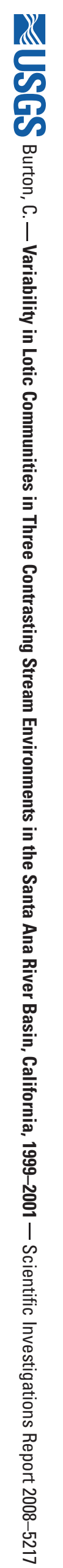

